\title{
Pyrochlore-Rich Titanate Ceramics for the Immobilization of Plutonium: Redox Effects on Phase Equilibria in Cerium- and Thorium- Substituted Analogs
}

F. J. Ryerson, B. Ebbinghaus

Lawrence

May 25, 2000

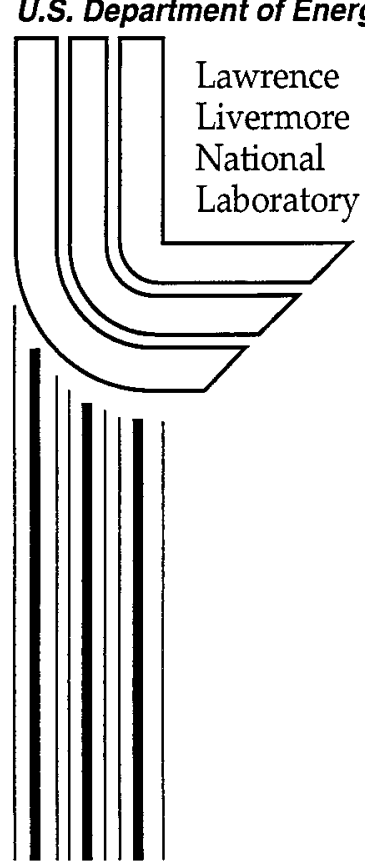




\section{DISCLAIMER}

This document was prepared as an account of work sponsored by an agency of the United States Government. Neither the United States Government nor the University of California nor any of their employees, makes any warranty, express or implied, or assumes any legal liability or responsibility for the accuracy, completeness, or usefulness of any information, apparatus, product, or process disclosed, or represents that its use would not infringe privately owned rights. Reference herein to any specific commercial product, process, or service by trade name, trademark, manufacturer, or otherwise, does not necessarily constitute or imply its endorsement, recommendation, or favoring by the United States Government or the University of California. The views and opinions of authors expressed herein do not necessarily state or reflect those of the United States Government or the University of California, and shall not be used for advertising or product endorsement purposes.

This work was performed under the auspices of the U. S. Department of Energy by the University of California, Lawrence Livermore National Laboratory under Contract No. W-7405-Eng-48.

This report has been reproduced

directly from the best available copy.

Available to DOE and DOE contractors from the

Office of Scientific and Technical Information

P.O. Box 62, Oak Ridge, TN 37831

Prices available from (423) 576-8401

http://apollo.osti.gov/bridge/

Available to the public from the

National Technical Information Service

U.S. Department of Commerce 5285 Port Royal Rd., Springfield, VA 22161

http://www.ntis.gov/

OR

Lawrence Livermore National Laboratory

Technical Information Department's Digital Library

http://www.llnl.gov/tid/Library.html 
Pyrochlore-rich titanate ceramics for the immobilization of plutonium: Redox effects on phase equilibria in cerium- and thorium- substituted analogs

by

F.J. Ryerson ${ }^{1}$ and Bartley Ebbinghaus ${ }^{2}$

1. Earth and Environmental Sciences

Lawrence Livermore National Laboratory

Livermore, CA 94550

2. Chemistry and Material Sciences

Lawrence Livermore National Laboratory

Livermore, CA 94550

UCRL-ID-139092 
Abstract. Three compositions representing plutonium-free analogs of a proposed Ca-Ti-Gd-HfU-Pu oxide ceramic for the immobilization of plutonium were equilibrated at $1 \mathrm{~atm}, 1350^{\circ} \mathrm{C}$ over a range of oxygen fugacities between air and that equivalent to the iron-wüstite buffer. The cerium analog replaces $\mathrm{Pu}$ on a mole-per-mole basic with $\mathrm{Ce}$; the thorium analog replaces $\mathrm{Pu}$ with $\mathrm{Th}$. A third material has $10 \mathrm{wt} \% \mathrm{Al}_{2} \mathrm{O}_{3}$ added to the cerium analog to encourage the formation of a Hfanalog of, $\mathrm{CaHfTi}_{2} \mathrm{O}_{7}$, zirconolite, which is referred to as hafnolite. The predominant phase produced in each formulation under all conditions is pyrochlore, $\mathrm{A}_{2} \mathrm{~T}_{2} \mathrm{O}_{7}$, where the $\mathrm{T}$ site is filled by $\mathrm{Ti}$, and $\mathrm{Ca}$, the lanthanides, $\mathrm{Hf}, \mathrm{U}$ and $\mathrm{Pu}$ are accommodated on the $\mathrm{A}$-site. Other lanthanide and uranium-bearing phases encountered include brannerite $\left(\mathrm{UTi}_{2} \mathrm{O}_{6}\right)$, hafnolite $\left(\mathrm{CaHfTi}_{2} \mathrm{O}_{7}\right)$, perovskite $\left(\mathrm{CaTiO}_{3}\right)$ and a calcium-lanthanide aluminotitanate with nominal stoichiometry $(\mathrm{Ca}, \mathrm{Ln}) \mathrm{Ti}_{2} \mathrm{Al}_{9} \mathrm{O}_{19}$, where $\mathrm{Ln}$ is a lanthanide. The phase compositions show progressive shifts with decreasing oxygen fugacity. All of the phases observed have previously been identified in titanatebased high-level radioactive waste ceramics and demonstrate the flexibility of these ceramics to variations in processing parameters. The main variation is an increase in the uranium concentrations of pyrochlore and brannerite which must be accommodated by variations in modal abundance. Pyrochlore compositions are consistent with existing spectroscopic data suggesting that uranium is predominantly pentavalent in samples synthesized in air. A simple model based on ideal stoichiometry suggests the $\mathrm{U}^{+4} / \Sigma \mathrm{U}$ varies linearly with $\log \mathrm{fO}_{2}$ and that all of the uranium is quadravalent at the iron-wüstite buffer.

\section{Introduction}

The Plutonium Immobilization Program has developed a ceramic form suitable for immobilizing surplus plutonium the ceramic is formed by a relatively simple cold press and sinter process The composition and mineralogy of the form is determined by the phase equilibria (Ebbinghaus et al. 1999) and is a function of potential processing conditions. The partitioning of the various wastestream components (plutonium, impurity elements and additives) among the crystalline constituents of that phase assemblage may also vary with form composition and processing conditions. Hence, an understanding of the relevant phase equilibria and partitioning relationships as a function of composition and processing conditions is necessary to insure the chemical durability and criticality safety of the resultant wasteform. Chemical durability is most strongly influenced by the mineralogy of the wasteform - are the appropriate phases formed under 
a given set of processing conditions, while criticality safety is more strongly influenced by the chemical partitioning - what is the ratio of neutron emittors to absorbers in the constituent phases.

The baseline formulation (Table 1$)$ is designed to produce a pyrochlore $\left(\mathrm{A}_{2} \mathrm{~T}_{2} \mathrm{O}_{7}\right)$-brannerite $\left(\mathrm{AT}_{2} \mathrm{O}_{6}\right)$-rutile $\left(\mathrm{TO}_{2}\right)$ assemblage (Ebbinghaus et al. 1999). The T-site in each of these minerals is occupied primarily by titanium. Uranium can also be present in the plutonium feed materials, and

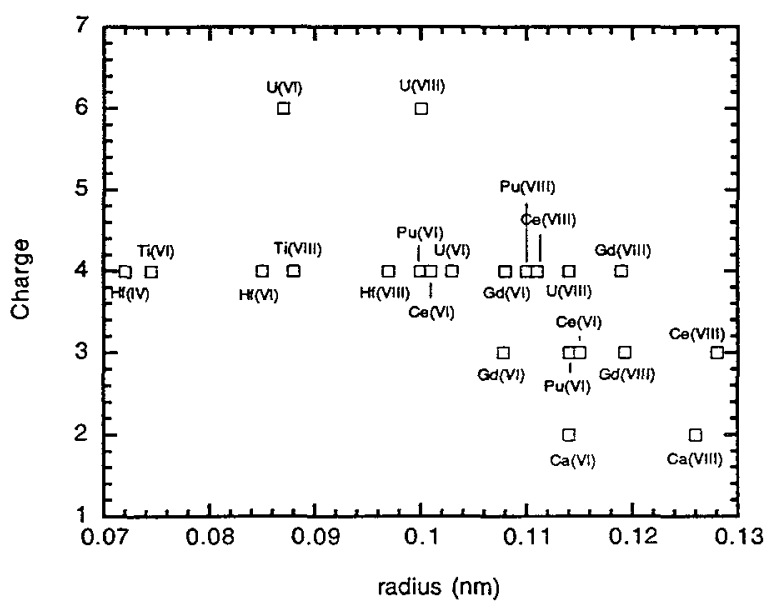

Figure 1. Radius charge relationship for elements relevant to $\mathrm{Pu}$ immobilization. is added to the formulation to stabilize pyrochlore. The formulation also contains hafnium, gadolinium and uranium to act as both neutron absorbers in the wasteform itself, or in possible dissolution products (Ebbinghaus et al, 1999). Plutonium, uranium, hafnium and the lanthanides are incorporated in both pyrochlore and brannerite and predominately occupy the $\mathrm{A}$ site, which in pyrochlore can also contain a substantial amount of calcium. The formulation contains at least three elements that are commonly found in more than one oxidation state: $\mathrm{Pu}(+3,+4), \mathrm{U}(+4,+5,+6)$ and $\mathrm{Ti}(+3,+4$,

Figure 1). As these are major constituents of the wasteform, variation in the oxygen fugacity during processing is expected to effect the nature of the resulting phase assemblage. Here we present phase equilibria obtained for cerium and thorium-substituted analogs of the baseline formulation (Table 1) for oxygen fugacities between the iron-wüstite buffer and air at $1350^{\circ} \mathrm{C}$.

Table 1. Starting compositions (wt\%)

\begin{tabular}{lrrr}
\hline & Ce analog & $\mathrm{Ce} / \mathrm{Al}$ analog & Th analog \\
\hline $\mathrm{Al}_{2} \mathrm{O}_{3}$ & 0.00 & 10.00 & 0.00 \\
$\mathrm{CaO}$ & 10.48 & 9.32 & 9.93 \\
$\mathrm{TiO}_{2}$ & 36.90 & 33.55 & 35.77 \\
$\mathrm{HfO}_{2}$ & 11.20 & 10.02 & 10.73 \\
$\mathrm{CeO}_{2}$ & 8.23 & 7.35 & 0.00 \\
$\mathrm{Gd}_{2} \mathrm{O}_{3}$ & 8.33 & 7.52 & 7.93 \\
$\mathrm{ThO}_{2}$ & 0.00 & 0.00 & 12.02 \\
$\mathrm{UO}_{2}$ & 23.85 & 22.23 & 23.63 \\
\hline Total & 100.00 & 100.00 & 100.00
\end{tabular}


The baseline mixtures are formulated under the assumption that either cerium or thorium will replace plutonium in the target phases. Cerium exists as both $\mathrm{Ce}^{+3}$ and $\mathrm{Ce}^{+4}$ with cationic radii close to that of $\mathrm{Pu}^{+3}$ and $\mathrm{Pu}^{+4}$ and represents a reasonable analog for plutonium under our processing conditions (Table 1). Thorium exists as a quadravalent cation with an ionic radius close to that of $\mathrm{Pu}^{+4}$ (Table 1) and allows us to evaluate the effects of uranium oxidation in the absence of another variable valence cation.

Previous results ( $c f$., Ebbinghaus et al, 1999) demonstrate that addition of aluminum to the baseline formulation stabilizes a hafnium-rich analog of zirconolite $\left(\mathrm{ABT}_{2} \mathrm{O}_{7}\right.$, hereafter referred to as "hafnolite") that also incorporates $\mathrm{Pu}$ (or its analog element) and $\mathrm{U}$ as well as the lanthanides. To evaluate the phase equilibria of hafnolite-bearing assemblages, we have also investigated a composition in which $10 \mathrm{wt} \% \mathrm{Al}_{2} \mathrm{O}_{3}$ was added to the cerium-substituted formulation (Table 1).

\section{Starting materials and experimental methods}

The goal of this investigation is to assess the effects of temperature and oxygen fugacity on phase equilibria at constant temperature, rather than to evaluate process control parameters on other product characteristics. This allows us to make relatively small batches, $1-2 \mathrm{~g}$, of starting materials from mixtures of hydroxides, nitrates, hydrated-nitrates, carbonates, ammoniates and oxides (Table 2). As many of the starting materials

\begin{tabular}{|c|c|}
\hline $\mathrm{Al}_{2} \mathrm{O}_{3}$ & $\mathrm{Al}(\mathrm{OH})_{3}$ \\
\hline $\mathrm{CaO}$ & $\mathrm{CaCO}_{3}$ \\
\hline $\mathrm{TiO}_{2}$ & $\mathrm{TiO}_{2}$ (rutile) \\
\hline $\mathrm{HfO}_{2}$ & $\mathrm{HfO}_{2}$ \\
\hline $\mathrm{CeO}_{2}$ & $\left(\mathrm{NH}_{4}\right)_{2} \mathrm{Ce}\left(\mathrm{NO}_{3}\right)_{6}$ \\
\hline $\mathrm{Gd}_{2} \mathrm{O}_{3}$ & $\mathrm{Gd}\left(\mathrm{NO}_{3}\right)_{3} \cdot 6 \mathrm{H}_{2} \mathrm{O}$ \\
\hline $\mathrm{ThO}_{2}$ & $\mathrm{ThO}_{2}$ \\
\hline $\mathrm{UO}_{2}$ & $\mathrm{UO}_{2}\left(\mathrm{NO}_{3}\right)_{2} \cdot 6 \mathrm{H}_{2} \mathrm{O}$ \\
\hline
\end{tabular}

were extremely hygroscopic, we determined the useful oxide yield of each reagent by loss on combustion. Starting materials were ground by hand under ethanol in an alumina mortar and pestle. The resulting slurry was dried under a heat lamp producing a paste; due to the hygroscopic nature of the material, a fully dry powder was never obtained at this stage of the preparation procedure. The paste was then transferred to a Pt crucible and calcined in air at $1000^{\circ} \mathrm{C}$ for at least 3 hours. This calcine was then reground by hand under ethanol in an alumina mortar and pestle 
prior to the addition of a polyvinyl alcohol solution to act as a binder. The calcine-polyvinyl alcohol slurry was dried under a heat lamp and then ground dry in an alumina mortar and pestle to obtain a free-flowing powder. Individual samples were hand-pressed in a stainless steel die and piston to produce disks approximately $2 \mathrm{~mm}$ thick, with an outside diameter of $<5 \mathrm{~mm}$, weighing $\sim 50 \mathrm{mg}$.

Table 3. Run Conditions and results

\begin{tabular}{lllll}
\hline $1 / 3$ & $\mathrm{Hf}-\mathrm{Ce}-\mathrm{U}$ & 1350 & -0.69 & pyr, rut \\
$1 / 4$ & $\mathrm{Hf}-\mathrm{Ce}-\mathrm{U}$ & 1350 & -2.6 & pyr, brn, rut \\
$1 / 5$ & $\mathrm{Hf}-\mathrm{Ce}-\mathrm{U}$ & 1350 & -5.05 & pyr, rut \\
$1 / 6$ & $\mathrm{Hf}-\mathrm{Ce}-\mathrm{U}$ & 1350 & -5.9 & pyr, rut \\
$1 / 9$ & $\mathrm{Hf}-\mathrm{Ce}-\mathrm{U}$ & 1350 & -6.83 & pyr, hfn, pv, rut \\
$1 / 7$ & $\mathrm{Hf}-\mathrm{Ce}-\mathrm{U}$ & 1350 & -8.00 & pyr, hfn, pv, rut \\
$1 / 8$ & $\mathrm{Hf}-\mathrm{Ce}-\mathrm{U}$ & 1350 & -10.06 & pyr, hfn, pv \\
$7 / 3$ & $\mathrm{Hf}-\mathrm{Ce}-\mathrm{U}+\mathrm{Al}_{2} \mathrm{O}_{3}$ & 1350 & -0.69 & pyr, brn, hfn, psb \\
$7 / 4$ & $\mathrm{Hf}-\mathrm{Ce}-\mathrm{U}+\mathrm{Al}_{2} \mathrm{O}_{3}$ & 1350 & -2.6 & pyr, hfn, brn, rut, CTA \\
$7 / 5$ & $\mathrm{Hf}-\mathrm{Ce}-\mathrm{U}+\mathrm{Al}_{2} \mathrm{O}_{3}$ & 1350 & -5.05 & pyr, hfn, brn, rut, CTA \\
$7 / 6$ & $\mathrm{Hf}-\mathrm{Ce}-\mathrm{U}+\mathrm{Al}_{2} \mathrm{O}_{3}$ & 1350 & -5.9 & pyr, hfn, rut, CTA \\
$7 / 9$ & $\mathrm{Hf}-\mathrm{Ce}-\mathrm{U}+\mathrm{Al}_{2} \mathrm{O}_{3}$ & 1350 & -6.83 & pyr, hfn, pv, CTA \\
$7 / 7$ & $\mathrm{Hf}-\mathrm{Ce}-\mathrm{U}+\mathrm{Al}_{2} \mathrm{O}_{3}$ & 1350 & -8.00 & pyr, hfn, pv, CTA \\
$7 / 8$ & $\mathrm{Hf}-\mathrm{Ce}-\mathrm{U}+\mathrm{Al}_{2} \mathrm{O}_{3}$ & 1350 & -10.06 & pyr, hfn, pv, CTA \\
$8 / 3$ & $\mathrm{Hf}-\mathrm{Th}-\mathrm{U}$ & 1350 & -0.69 & pyr, brn, rut \\
$8 / 4$ & $\mathrm{Hf}-\mathrm{Th}-\mathrm{U}$ & 1350 & -2.6 & pyr, brn, rut, hfn \\
$8 / 5$ & $\mathrm{Hf}-\mathrm{Th}-\mathrm{U}$ & 1350 & -5.05 & pyr, brn, rut, hfn \\
$8 / 6$ & $\mathrm{Hf}-\mathrm{Th}-\mathrm{U}$ & 1350 & -5.9 & pyr, brn, rut, hfn \\
$8 / 9$ & $\mathrm{Hf}-\mathrm{Th}-\mathrm{U}$ & 1350 & -6.83 & pyr, brn, rut, hfn \\
$8 / 7$ & $\mathrm{Hf}-\mathrm{Th}-\mathrm{U}$ & 1350 & -8.00 & pyr, brn, rut \\
$8 / 8$ & $\mathrm{Hf}-\mathrm{Th}-\mathrm{U}$ & 1350 & -10.06 & pyr, brn, rut,hfn \\
\hline
\end{tabular}

rut=rutile, $\mathrm{pyr}=$ pyrochlore, $\mathrm{hfn}=$ hafnolite, brn = brannerite,

$\mathrm{ps}=\mathrm{Al}-\mathrm{Ti}$ psuedobrookite, $\mathrm{pv}=$ perovskite, $\mathrm{CTA}=\mathrm{Calcium}$-lathanide titanoaluminate

A bottom-loading Deltech furnace was used to anneal samples equilibrated in air. Samples were loaded in open Pt crucibles that were then placed on the lower platen of the furnace and hydraulically lifted into the furnace that was already at run temperature. Temperature was monitored using a Pt-Rh thermocouple placed within $5 \mathrm{~mm}$ of the sample. Samples reached run conditions within 2-4 minutes after insertion, and run duration was always in excess of 23 hours. Runs were quenched by lowering the platen and removing the crucibles that then cooled in air. The lower oxygen fugacities runs were equilibrated in Deltech furnace equipped with a vertical alumina muffle tube, and oxygen fugacity was controlled using $\mathrm{CO}-\mathrm{CO}_{2}$ gas mixtures. The $\mathrm{fO}_{2}$ was 
monitored with a zirconia sensor cell and temperature was measured using a $\mathrm{Pt}-\mathrm{Rh}$ thermocouple placed within $2 \mathrm{~mm}$ of the sample that was suspended from an alumina rod. The samples were contained in a $5 \mathrm{~mm}$ diameter Pt capillary that was partially crimped at both ends allowing continual contact between the sample and the gas mixture. The samples were plunged into the top of the furnace at run conditions and reached final temperature within 5 minutes. Samples were quenched by pulling the alumina rod-sample assembly from the top of the furnace and cooled in air. Run conditions and products are given in Table 3.

\section{Sample characterization}

The sintered disks were mounted in epoxy and then polished with alumina grits prior to final polishing on a colloidal silica polisher. The polished mounts were then carbon coated for SEM and electron probe analysis. Compositional analysis was performed on a JEOL-733 electron

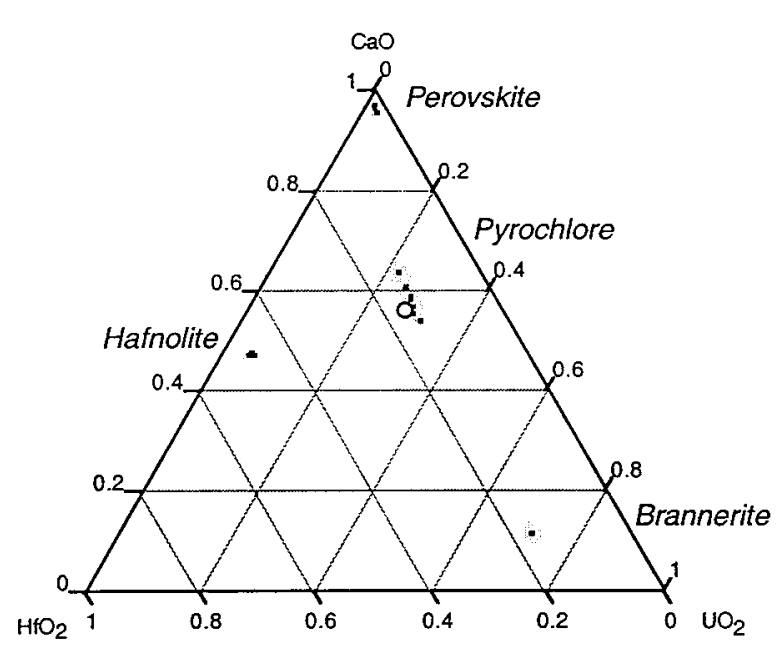

Figure 2. $\mathrm{CaO}-\mathrm{HfO}_{2}-\mathrm{UO}_{2}$ diagram showing the compositions of perovskite, pyrochlore, hafnolite and brannerites from Ce-analog materials sintered at $1350^{\circ} \mathrm{C}$. Pyrochlores become richer in uranium with decreasing $\mathrm{fO}_{2}$. The bulk composition is given by the open circle. probe using wavelength dispersive analysis. The probe was operated at an accelerating voltage of 15 KV with a beam current (measured in a Faraday cup embedded in the sample stage) of 30-100 na. X-ray intensities were reduced to oxides using the $\mathrm{ZAF}$ method as revised by Armstrong et al. (1995). Two notable $x$-ray interferences were observed. The $\mathrm{Ce}_{L \beta 1}$ line interferes with the $\mathrm{Gd}{ }_{L \alpha 1}$ requiring the use of the $\mathrm{Gd}_{L \beta 1}$ line. In the Th-bearing samples, the $\mathrm{Th}_{M \beta 1}$ interferes with the $\mathrm{U}_{M \alpha 1-1}$ requiring use of the $\mathrm{U}_{M \beta l}$ line.

\section{Results}

\subsection{Cerium-substituted analog}

The phase assemblages for these experiments are given in Table 3 and the compositions of the individual phases in Table 4. Runs were performed in air, and at 6 other oxygen fugacities. The assemblage found in the higher $\mathrm{fO}_{2}$ runs (-log $\mathrm{fO}_{2}$ $<5.9$ ) is pyrochlore, rutile, \pm brannerite. As $\mathrm{fO}_{2}$ decreases, brannerite is not observed, and is replaced by hafnolite and perovskite. 


\begin{tabular}{|c|c|c|c|c|c|c|c|c|c|c|c|c|c|c|}
\hline \multirow{9}{*}{$\begin{array}{l}\mathrm{Al}_{2} \mathrm{O}, \\
\mathrm{CaO} \mathrm{O} \\
\mathrm{TO}_{2} \\
\mathrm{Ce}_{2} \mathrm{O} \\
\mathrm{Gd}_{2} \mathrm{O}, \\
\mathrm{HOO}_{2} \\
\mathrm{UO}_{2}\end{array}$} & \multicolumn{4}{|c|}{$\begin{array}{c}1-3 \\
\log f \mathrm{O}_{2}=-0.69\end{array}$} & \multicolumn{6}{|c|}{$\begin{array}{c}1-4 \\
\log \mathrm{fO}_{2}=-2.6\end{array}$} & \multicolumn{4}{|c|}{$\begin{array}{c}1-5 \\
\log f O_{2}=-5.05\end{array}$} \\
\hline & $\begin{array}{r}\text { Pyrochlore } \\
\text { wt\% }\end{array}$ & $\begin{array}{r}9 \\
\text { std dev }\end{array}$ & $\begin{array}{r}\text { Ruile } \\
\text { wt\% }\end{array}$ & std dev & $\begin{array}{r}\text { Pyrochlore } \\
\text { wt } \%\end{array}$ & $\begin{array}{r}6 \\
\text { std dev }\end{array}$ & $\begin{array}{r}\text { Brannerite } \\
w t \%\end{array}$ & $\begin{array}{r}5 \\
\text { std dev }\end{array}$ & $\begin{array}{l}\text { Rutile } \\
\text { wt\% }\end{array}$ & std dev & $\begin{array}{r}\text { Pyrochlore } \\
\text { wt\% }\end{array}$ & $\begin{array}{r}6 \\
\text { std dev }\end{array}$ & $\begin{array}{l}\text { Rutile } \\
\text { wt\% }\end{array}$ & $\begin{aligned} 4 \\
\text { std dev }\end{aligned}$ \\
\hline & 0.16 & 0.01 & 0.69 & 0.03 & 0.27 & 0.01 & 0.43 & 0.01 & 0.53 & 0.02 & 0.12 & 0.01 & 0.43 & 0.01 \\
\hline & 12.53 & 1.17 & 0.01 & 0.01 & 12.08 & 0.13 & 1.17 & 0.25 & 0.15 & 0.06 & 10.92 & 0.13 & 0.15 & 0.03 \\
\hline & 33.86 & 1.27 & 78.30 & 0.95 & 33.99 & 0.29 & 39.81 & 0.39 & 78.68 & 0.27 & 35.33 & 0.19 & 81.81 & 0.53 \\
\hline & 8.87 & 0.60 & 0.04 & 0.02 & 8.89 & 0.23 & 8.79 & 0.34 & 0.07 & 0.02 & 8.53 & 0.16 & 0.13 & 0.06 \\
\hline & 9.30 & 0.95 & 0.00 & 0.00 & 9.62 & 0.29 & 6.34 & 0.27 & 0.16 & 0.05 & 8.95 & 0.21 & 0.14 & 0.05 \\
\hline & 10.23 & 0.47 & 18.50 & 0.85 & 10.36 & 0.17 & 6.24 & 0.41 & 17.44 & 0.22 & 9.98 & 0.21 & 15.48 & 0.26 \\
\hline & 20.95 & 1.91 & 2.39 & 0.20 & 23.72 & 0.31 & 34.69 & 0.80 & 2.45 & 0.09 & 24.08 & 0.24 & 1.62 & 0.05 \\
\hline Total & 95.89 & & 99.93 & & 98.94 & & $97.48-$ & & 99.47 & $\begin{array}{ll}0.33 \\
\end{array}$ & 97.91 & & 99.76 & 0.43 \\
\hline Al & 0.015 & 0.002 & 0.012 & 0.001 & 0.024 & 0.001 & 0.033 & 0.001 & 0.010 & 0.000 & 0.011 & 0.001 & 0.007 & 0.000 \\
\hline $\mathrm{Ca}$ & 1.012 & 0.041 & 0.000 & 0.000 & 0.968 & 0.013 & 0.081 & 0.017 & 0.002 & 0.001 & 0.888 & 0.009 & 0.002 & 0.001 \\
\hline $\mathbf{T i}$ & 1.925 & 0.059 & 0.898 & 0.006 & 1.911 & 0.006 & 1.930 & 0.019 & 0.903 & 0.002 & 2.016 & 0.012 & 0.918 & 0.001 \\
\hline ce & 0.245 & 0.006 & 0.000 & 0.000 & 0.243 & 0.005 & 0.208 & 0.008 & 0.000 & 0.000 & 0.237 & 0.005 & 0.001 & 0.000 \\
\hline Gd & 0.232 & 0.012 & 0.000 & 0.000 & 0.238 & 0.006 & 0.136 & 0.006 & 0.001 & 0.000 & 0.225 & 0.005 & 0.001 & 0.000 \\
\hline Hf & 0.221 & 0.005 & 0.081 & 0.004 & 0.221 & 0.004 & 0.115 & 0.008 & 0.076 & 0.001 & 0.216 & 0.004 & 0.066 & 0.001 \\
\hline $\mathrm{U}$ & 0.351 & 0.018 & 0.008 & 0.001 & 0.395 & 0.004 & 0.498 & 0.010 & 0.008 & 0.000 & 0.407 & 0.003 & 0.005 & 0.000 \\
\hline Catatoms & 4.000 & 0.000 & 1.000 & 0.000 & 4.000 & 0.000 & 3.000 & 0.000 & 1.000 & 0.000 & 4.000 & 0.000 & 1.000 & 0.000 \\
\hline Oxygen & 6.743 & 0.046 & 1.994 & 0.000 & 6.779 - & & 5.731 - & & $1.992-$ & & $6.875-$ & & $1.993-$ & \\
\hline $\mathrm{Ce}^{4} \sqrt{\mathrm{C} e}$ & 0.33 & & 0.00 & & 0.26 & & 0.26 & & 0.00 & & 0.18 & & 0.00 & \\
\hline $\mathrm{Ca}$ & 0.000 & & 0.000 & & 0.000 & & 0.000 & & 0.000 & & 0.000 & & 0.000 & \\
\hline $\mathrm{Gd}$ & 0.000 & & 0.000 & & 0.000 & & 0.000 & & 0.000 & & 0.000 & & 0.000 & \\
\hline$c_{e} \cdot$ & 0.000 & & 0.000 & & 0.000 & & 0.000 & & 0.000 & & 0.000 & & 0.000 & \\
\hline $\mathrm{Ce}^{4}$. & 0.000 & & 0.000 & & 0.000 & & 0.000 & & 0.000 & & 0.000 & & 0.000 & \\
\hline Sum & 0.000 & & 0.000 & & 0.000 & & 0.000 & & 0.000 & & 0.000 & & 0.000 & \\
\hline Charge & 0.000 & & 0.000 & & 0.000 & & 0.000 & & 0.000 & & 0.000 & & 0.000 & \\
\hline $\mathrm{ca}$ & 1.012 & & 0.000 & & 0.968 & & 0.081 & & 0.000 & & 0.888 & & 0.000 & \\
\hline Al & 0.000 & & 0.000 & & 0.000 & & 0.000 & & 0.000 & & 0.011 & & 0.000 & \\
\hline$c e "$ & 0.164 & & 0.000 & & 0.179 & & 0.153 & & 0.000 & & 0.195 & & 0.000 & \\
\hline $\mathrm{Ce}^{-1}$ & 0.081 & & 0.000 & & 0.064 & & 0.055 & & 0.000 & & 0.042 & & 0.000 & \\
\hline$G d$ & 0.232 & & 0.000 & & 0.238 & & 0.136 & & 0.000 & & 0.225 & & 0.000 & \\
\hline Hf & 0.160 & & 0.000 & & 0.156 & & 0.078 & & 0.000 & & 0.216 & & 0.000 & \\
\hline $\mathbf{u}$ & 0.351 & & 0.000 & & 0.395 & & 0.498 & & 0.000 & & 0.407 & & 0.000 & \\
\hline Sum & 2.000 & & 0.000 & & 2.000 & & 1.000 & & 0.000 & & 1.984 & & 0.000 & \\
\hline Charge & 6.015 & & 0.000 & & 6.024 & & 4.033 & & 0.000 & & 5.969 & & 0.000 & \\
\hline $\mathrm{Ti}_{\mathrm{i}}$ & 1.925 & & 0.898 & & 1.911 & & 1.930 & & 0.903 & & 2.016 & & 0.918 & \\
\hline $\mathrm{Hf}$ & 0.061 & & 0.081 & & 0.065 & & 0.037 & & 0.076 & & 0.000 & & 0.066 & \\
\hline $\mathrm{Al}$ & 0.015 & & 0.012 & & 0.024 & & 0.033 & & 0.010 & & 0.000 & & 0.007 & \\
\hline \begin{tabular}{|l|} 
Sum \\
\end{tabular} & 2.000 & & 0.992 & & 2.000 & & 2.000 & & 0.988 & & 2.016 & & 0.991 & \\
\hline Charge & 7.985 & & 3.954 & & 7.976 & & 7.967 & & 3.943 & & 8.064 & & 3.956 & \\
\hline Total & 4.000 & & 0.992 & & 4.000 & & 3.000 & & 0.988 & & 4.000 & & 0.991 & \\
\hline Uo, & 2.617 & & 2.000 & & 2.478 & & 2.486 & & 2.000 & & 2.296 & & 2.000 & \\
\hline | Total & 4.000 & & 0.992 & & 4.000 & & 3.000 & & 0.988 & & 4.000 & & 0.991 & \\
\hline $\begin{array}{l}\text { Model } \\
\text { Oxygens }\end{array}$ & 7.000 & & 1.977 & & 7.000 & & 6.000 & & 1.971 & & 7.000 & & 1.978 & \\
\hline
\end{tabular}




\begin{tabular}{|c|c|c|c|c|c|c|c|c|c|c|c|c|c|c|c|c|c|c|}
\hline \multirow{10}{*}{$\begin{array}{l}\mathrm{Al}_{2} \mathrm{O}_{3} \\
\mathrm{CaO} \\
\mathrm{TrO} \\
\mathrm{Ce}_{2} \mathrm{O}_{2} \\
\mathrm{Gd}_{2} \mathrm{O}, \\
\mathrm{HOO}_{2} \\
\mathrm{UO}_{2}\end{array}$} & \multicolumn{4}{|c|}{$\begin{array}{c}1-6 \\
\log f O_{z}=-5.9\end{array}$} & \multicolumn{8}{|c|}{$\begin{array}{c}1-7 \\
\log f O_{3}=-8.00\end{array}$} & \multicolumn{6}{|c|}{$\begin{array}{c}1-8 \\
\log f O_{2}=-10.06\end{array}$} \\
\hline & Pyrochlore & 6 & Rutile & & Pyrochlore & 6 & Hafnolite & 6 & Perovskite & 5 & Rutile & & Pyrochlore & 6 & Hafnolite & 6 & Pemovskite & \\
\hline & & std dev & we\% & std dev & $w 1 \%$ & std dev & $w 1 \%$ & std dev & $w t \%$ & std dev & wt\% & std dev & wto & std dev & $w t \%$ & std dev & $w t \%$ & std dev \\
\hline & 0.12 & 0.01 & 0.43 & 0.01 & 0.10 & 0.01 & 2.21 & 0.04 & 0.73 & 0.03 & 0.32 & 0.01 & 0.10 & 0.01 & 1.77 & 0.03 & 0.56 & 0.05 \\
\hline & 10.85 & 0.08 & 0.14 & 0.03 & 10.17 & 0.05 & 9.93 & 0.12 & 20.35 & 0.12 & 0.15 & 0.06 & 9.65 & 0.08 & 9.48 & 0.06 & 20.03 & 0.21 \\
\hline & 35.78 & 0.19 & 83.62 & 0.11 & 35.83 & 0.11 & 37.03 & 0.58 & 48.43 & 0.25 & 83.67 & 0.43 & 35.69 & 0.25 & 38.30 & 0.20 & 47.84 & 0.31 \\
\hline & 8.41 & 0.24 & 0.06 & 0.05 & 7.48 & 0.23 & 3.19 & 0.11 & 23.68 & 0.45 & 0.01 & 0.03 & 6.93 & 0.19 & 3.19 & 0.13 & 23.05 & 1.22 \\
\hline & 8.82 & 0.20 & 0.14 & 0.04 & 9.18 & 0.19 & 5.34 & 0.20 & 4.98 & 0.13 & 0.01 & 0.01 & 9.16 & 0.15 & 5.89 & 0.23 & 5.25 & 0.36 \\
\hline & 9.94 & 0.18 & 14.08 & 0.27 & 10.64 & 0.21 & 37.56 & 1.00 & 1.23 & 0.08 & 14.74 & 0.22 & 10.12 & 0.20 & 35.45 & 0.83 & 1.26 & 0.32 \\
\hline & 24.11 & 0.39 & 1.22 & 0.06 & 25.37 & 0.08 & 4.71 & 0.10 & 1.64 & 0.07 & 0.69 & 0.04 & 26.40 & 0.54 & 5.43 & 0.20 & 2.34 & 0.78 \\
\hline Total & 98.03 & & 99.68 & 0.26 & 98.76 . & & 99.97 - & & 101.02 & & 99.59 & 0.20 & 98.05 & & 99.51 - & & 100.32 & \\
\hline $\mathrm{Al}$ & 0.011 & 0.001 & 0.007 & 0.000 & 0.009 & 0.001 & 0.187 & 0.002 & 0.024 & 0.001 & 0.006 & 0.000 & 0.009 & 0.001 & 0.151 & 0.002 & 0.019 & 0.002 \\
\hline $\mathrm{Ca}$ & 0.879 & 0.006 & 0.002 & 0.000 & 0.831 & 0.004 & 0.762 & 0.005 & 0.622 & 0.002 & 0.002 & 0.001 & 0.801 & 0.006 & 0.732 & 0.004 & 0.621 & 0.006 \\
\hline $\mathrm{Ti}$ & 2.035 & 0.007 & 0.926 & 0.002 & 2.056 & 0.006 & 1.996 & 0.020 & 1.039 & 0.006 & 0.928 & 0.002 & 2.080 & 0.010 & 2.076 & 0.013 & 1.040 & 0.004 \\
\hline$\alpha$ & 0.233 & 0.006 & 0.000 & 0.000 & 0.209 & 0.007 & 0.084 & 0.003 & 0.247 & 0.004 & 0.000 & 0.000 & 0.197 & 0.006 & 0.084 & 0.003 & 0.244 & 0.013 \\
\hline $\mathrm{Gd}$ & 0.221 & 0.005 & 0.001 & 0.000 & 0.232 & 0.005 & 0.127 & 0.005 & 0.047 & 0.001 & 0.000 & 0.000 & 0.235 & 0.004 & 0.141 & 0.006 & 0.050 & 0.004 \\
\hline $\mathrm{Hf}$ & 0.215 & 0.004 & 0.059 & 0.001 & 0.232 & 0.004 & 0.769 & 0.025 & 0.010 & 0.001 & 0.062 & 0.001 & 0.224 & 0.004 & 0.729 & 0.016 & 0.010 & 0.003 \\
\hline $\mathrm{U}$ & 0.406 & 0.006 & 0.004 & 0.000 & 0.431 & 0.001 & 0.075 & 0.001 & 0.010 & 0.000 & 0.002 & 0.000 & 0.455 & 0.010 & 0.087 & 0.003 & 0.015 & 0.005 \\
\hline \begin{tabular}{|c|c|c|c|} 
Catatos \\
\end{tabular} & 4.000 & 0.000 & 1.000 & 0.000 & 4.000 & 0.000 & 4.000 & 0.000 & 2.000 & 0.000 & 1.000 & 0.000 & 4.000 & 0.000 & 4.000 & 0.000 & 2.000 & 0.000 \\
\hline Oxygen & 6.888 & & 1.994 & & $6.943-$ & & $7.039-$ & & $3.219-$ & & 1.995 & & 6.979 & & 7.080 & & 3.223 - & \\
\hline $\mid c e^{4} / \Sigma c_{e}$ & 0.15 & & 0.00 & & 0.07 & & 0.07 & & 0.07 & & 0.00 & & 0.00 & & 0.00 & & 0.00 & \\
\hline $\mathrm{Ca}$ & 0.000 & & 0.000 & & 0.000 & & 0.762 & & 0.000 & & 0.000 & & 0.000 & & 0.732 & & 0.000 & \\
\hline Gd & 0.000 & & 0.000 & & 0.000 & & 0.127 & & 0.000 & & 0.000 & & 0.000 & & 0.141 & & 0.000 & \\
\hline $\mathrm{Ce}^{* 3}$ & 0.000 & & 0.000 & & 0.000 & & 0.078 & & 0.000 & & 0.000 & & 0.000 & & 0.084 & & 0.000 & \\
\hline$\alpha^{\prime \prime}$ & 0.000 & & 0.000 & & 0.000 & & 0.006 & & 0.000 & & 0.000 & & 0.000 & & 0.000 & & 0.000 & \\
\hline Sum & 0.000 & & 0.000 & & 0.000 & & 0.967 & & 0.000 & & 0.000 & & 0.000 & & 0.957 & & 0.000 & \\
\hline Charge & 0.000 & & 0.000 & & 0.000 & & 2.162 & & 0.000 & & 0.000 & & 0.000 & & 2.139 & & 0.000 & \\
\hline $\mathrm{Ca}$ & 0.879 & & 0.000 & & 0.831 & & 0.000 & & 0.622 & & 0.000 & & 0.801 & & 0.000 & & 0.621 & \\
\hline $\mathrm{Al}$ & 0.011 & & 0.000 & & 0.009 & & 0.183 & & 0.024 & & 0.000 & & 0.009 & & 0.151 & & 0.019 & \\
\hline$\alpha e^{\prime \prime}$ & 0.199 & & 0.000 & & 0.194 & & 0.006 & & 0.229 & & 0.000 & & 0.197 & & 0.000 & & 0.244 & \\
\hline$c^{*}$ & 0.034 & & 0.000 & & 0.015 & & 0.000 & & 0.018 & & 0.000 & & 0.000 & & 0.000 & & 0.000 & \\
\hline $\mathrm{Gd}$ & 0.221 & & 0.000 & & 0.232 & & 0.000 & & 0.047 & & 0.000 & & 0.235 & & 0.000 & & 0.050 & \\
\hline Hf & 0.215 & & 0.000 & & 0.232 & & 0.769 & & 0.010 & & 0.000 & & 0.224 & & 0.729 & & 0.010 & \\
\hline $\mathrm{u}$ & 0.406 & & 0.000 & & 0.431 & & 0.075 & & 0.010 & & 0.000 & & 0.455 & & 0.087 & & 0.015 & \\
\hline Sum & 1.965 & & 0.000 & & 1.944 & & 1.033 & & 0.961 & & 0.000 & & 1.920 & & 0.967 & & 0.960 & \\
\hline Charge & 5.893 & & 0.000 & & 5.806 & & 3.944 & & 2.300 & & 0.000 & & 5.708 & & 3.717 & & 2.284 & \\
\hline $\mathrm{Ti}$ & 2.035 & & 0.926 & & 2.056 & & 1.996 & & 1.039 & & 0.928 & & 2.080 & & 2.076 & & 1.040 & \\
\hline $\mathrm{Hf}$ & 0.000 & & 0.059 & & 0.000 & & 0.000 & & 0.000 & & 0.062 & & 0.000 & & 0.000 & & 0.000 & \\
\hline Al & 0.000 & & 0.007 & & 0.000 & & 0.004 & & 0.000 & & 0.006 & & 0.000 & & 0.000 & & 0.000 & \\
\hline Sum & 2.035 & & 0.993 & & 2.056 & & 2.000 & & 1.039 & & 0.995 & & 2.080 & & 2.076 & & 1.040 & \\
\hline Charge & 8.140 & & 3.964 & & 8.223 & & 7.996 & & 4.156 & & 3.976 & & 8.318 & & 8.304 & & 4.162 & \\
\hline Total & 4.000 & & 0.993 & & 4.000 & & 4.000 & & 2.000 & & 0.995 & & 4.000 & & 4.000 & & 2.000 & \\
\hline
\end{tabular}




\begin{tabular}{|c|c|c|c|c|c|c|c|c|}
\hline \multirow{9}{*}{$\begin{array}{l}\mathrm{Al}_{2} \mathrm{O}, \\
\mathrm{CaO} \\
\mathrm{TOO}_{2} \\
\mathrm{Oe}_{2} \mathrm{O}, \\
\mathrm{Cd}_{2} \mathrm{O}, \\
\mathrm{HFO}_{2} \\
\mathrm{UO}_{2}\end{array}$} & \multicolumn{8}{|c|}{$\begin{array}{c}1-9 \\
\log f O_{2}=-6.83\end{array}$} \\
\hline & $\begin{array}{r}\text { Pyrochlore } \\
\text { wt\% }\end{array}$ & $\begin{array}{r}6 \\
\text { std dev }\end{array}$ & $\begin{array}{r}\text { Hafnolite } \\
w 1 \%\end{array}$ & $\begin{array}{r}6 \\
\text { std dev }\end{array}$ & $\begin{array}{r}\text { Perovskite } \\
\text { wi\% }\end{array}$ & $\begin{array}{r}6 \\
\text { std dev }\end{array}$ & $\begin{array}{r}\text { Rutile } \\
\text { wt\% }\end{array}$ & std dev \\
\hline & 0.12 & 0.03 & 2.40 & 0.09 & 0.77 & 0.04 & 0.36 & 0.01 \\
\hline & 10.36 & 0.09 & 9.92 & 0.13 & 20.51 & 0.96 & 0.12 & 0.04 \\
\hline & 35.56 & 0.18 & 36.42 & 0.22 & 48.35 & 0.43 & 83.49 & 0.74 \\
\hline & 7.99 & 0.13 & 3.30 & 0.23 & 22.74 & 1.69 & 0.11 & 0.03 \\
\hline & 8.82 & 0.15 & 5.46 & 0.11 & 5.23 & 0.43 & 0.01 & 0.02 \\
\hline & 10.24 & 0.23 & 36.47 & 0.63 & 0.97 & 0.09 & 14.25 & 0.22 \\
\hline & 24.73 & 0.24 & 4.94 & 0.13 & 1.47 & 0.04 & 0.94 & 0.05 \\
\hline Total & 97.81 & & 98.89 & & 100.04 & & 99.28 & 0.87 \\
\hline $\mathrm{Al}$ & 0.011 & 0.003 & 0.204 & 0.007 & 0.026 & 0.002 & 0.006 & 0.000 \\
\hline ca & 0.850 & 0.006 & 0.768 & 0.009 & 0.628 & 0.023 & 0.002 & 0.001 \\
\hline $\mathrm{Ti}_{\mathbf{i}}$ & 2.047 & 0.009 & 1.979 & 0.009 & 1.040 & 0.006 & 0.928 & 0.001 \\
\hline $\mathrm{Ce}$ & 0.224 & 0.004 & 0.087 & 0.006 & 0.238 & 0.020 & 0.001 & 0.000 \\
\hline Gd & 0.224 & 0.003 & 0.131 & 0.002 & 0.050 & 0.004 & 0.000 & 0.000 \\
\hline $\mathrm{Hf}$ & 0.224 & 0.005 & 0.752 & 0.014 & 0.008 & 0.001 & 0.060 & 0.001 \\
\hline $\mathrm{U}$ & 0.421 & 0.004 & 0.079 & 0.002 & 0.009 & 0.000 & 0.003 & 0.000 \\
\hline Catatoms & 4.000 & 0.000 & 4.000 & 0.000 & 2.000 & 0.000 & 1.000 & 0.000 \\
\hline Oxygen & 6.921 & & 7.021 & & 3.215 & & 1.995 & \\
\hline $\mathrm{Ce}^{-1 / 2 C e}$ & 0.11 & & 0.11 & & 0.11 & & 0.00 & \\
\hline $\mathrm{Ca}$ & 0.000 & & 0.768 & & 0.000 & & 0.000 & \\
\hline Gd & 0.000 & & 0.131 & & 0.000 & & 0.000 & \\
\hline $\mathrm{Ce}^{\circ \prime}$ & 0.000 & & 0.077 & & 0.000 & & 0.000 & \\
\hline $\mathrm{Ce}^{-1}$ & 0.000 & & 0.010 & & 0.000 & & 0.000 & \\
\hline Sum & 0.000 & & 0.975 & & 0.000 & & 0.000 & \\
\hline Charge & 0.000 & & 2.198 & & 0.000 & & 0.000 & \\
\hline $\mathrm{Ca}$ & 0.850 & & 0.000 & & 0.628 & & 0.000 & \\
\hline $\mathrm{Al}$ & 0.011 & & 0.183 & & 0.026 & & 0.000 & \\
\hline $\mathrm{Ce}^{\prime}$ & 0.198 & & 0.077 & & 0.211 & & 0.000 & \\
\hline $\mathrm{Ce}^{-1}$ & 0.025 & & 0.010 & & 0.027 & & 0.000 & \\
\hline $\mathrm{Gd}$ & 0.224 & & 0.000 & & 0.050 & & 0.000 & \\
\hline $\mathrm{Hf}$ & 0.224 & & 0.752 & & 0.008 & & 0.000 & \\
\hline $\mathrm{U}$ & 0.421 & & 0.079 & & 0.009 & & 0.000 & \\
\hline Sum & 1.953 & & 1.102 & & 0.960 & & 0.000 & \\
\hline Charge & 5.845 & & 4.147 & & 2.295 & & 0.000 & \\
\hline$\pi$ & 2.047 & & 1.979 & & 1.040 & & 0.928 & \\
\hline $\mathrm{Hf}$ & 0.000 & & 0.000 & & 0.000 & & 0.060 & \\
\hline A) & 0.000 & & 0.021 & & 0.000 & & 0.006 & \\
\hline Sum & 2.047 & & 2.000 & & 1.040 & & 0.994 & \\
\hline Charge & 8.187 & & 7.979 & & 4.162 & & 3.971 & \\
\hline UO, & 2.196 & & 2.000 & & 2.000 & & 2.000 & \\
\hline Total & 4.000 & & 4.077 & & 2.000 & & 0.994 & \\
\hline $\begin{array}{l}\text { Model } \\
\text { Oxygens }\end{array}$ & 7.000 & & 7.162 & & 3.228 & & 1.986 & \\
\hline
\end{tabular}


LEFT INTENTIONALLY BLANK 

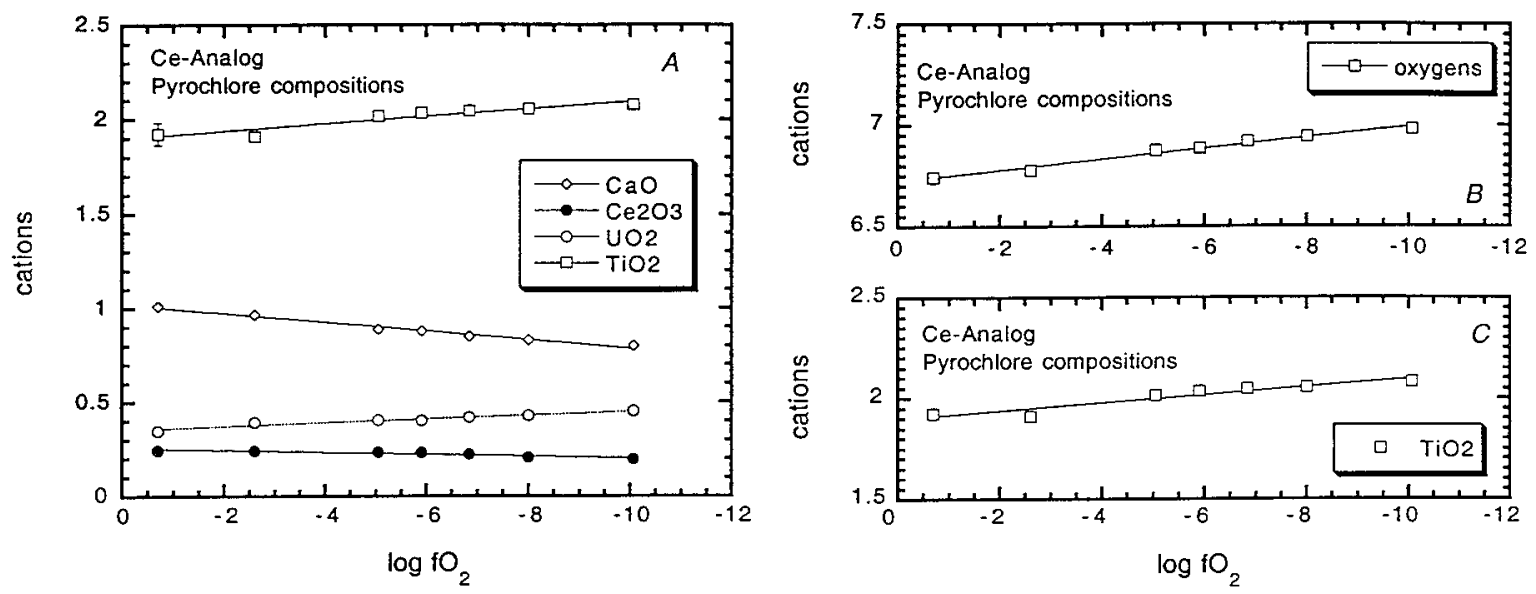

Figure 3. (A) Cation concentrations (normalized to 4 cations) in pyrochlore as a function of oxygen fugacity for the $\mathrm{Ce}$-analog mixture. (B) Oxygen concentration assuming trivalent $\mathrm{Ce}$ and quadravalent $\mathrm{U}$. (C) Ti concentration (normalized to 4 cations) in pyrochlore as a function of oxygen fugacity for the Ce-analog mixture.

The average phase compositions from the 1350_C runs (mole\%) are plotted onto the CaOHfO2-UO2 ternary in Figure 2. The most striking feature of these data is the linear trend, parallel to the $\mathrm{CaO}-\mathrm{UO}_{2}$ axis, formed by the pyrochlore compositions, indicating an inverse correlation between $\mathrm{CaO}$ and $\mathrm{UO}_{2}$ concentrations at close-to-constant $\mathrm{HfO}_{2}$. The run conducted in air anchors the $\mathrm{CaO}$-rich end of this array and $\mathrm{UO}_{2}$ is exchanged for $\mathrm{CaO}$ as $\mathrm{fO}_{2}$ is decreased.

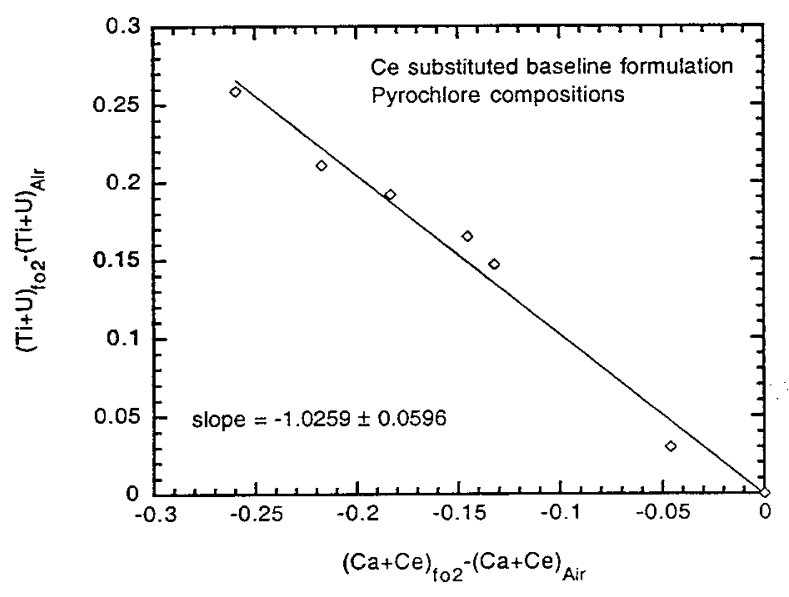

Figure 4. The variation in $\mathrm{Ti}+\mathrm{U}$ in pyrochlores sintered under reducing conditions relative to those sintered in air as a function of the change in $\mathrm{Ca}+\mathrm{Ce}$ sintered under reducing conditions relative to those sintered in air. The slope of unity indicates the coupling of these cations, and perhaps the destabilization of ceriumbearing pyrochlores at lower oxygen fugacities.
Brannerite plots close to the $\mathrm{UO}_{2}$ apex, and although the number of brannerite analyses is small they also appear to show a dependence on $\mathrm{fO}_{2}$ and $\mathrm{UO}_{2}$ decreasing at constant $\mathrm{Ca} / \mathrm{Hf}$ with increasing $\mathrm{fO}_{2}$ (Figure 2). Hafnolite plots along the $\mathrm{CaO}-\mathrm{HfO}_{2}$ join, and perovskite at the $\mathrm{CaO}$ apex; neither phase displays a great deal of chemical variation on this plot. Also plotted is the starting composition which falls just to the $\mathrm{HfO}_{2}$ side of the pyrochlore array. The proximity of the bulk and pyrochlore compositions is consistent with the modal predominance of this phase. On a weight percent basis, the plutonium analog-element, cerium, is equally partitioned between brannerite 
and pyrochlore, with pyrochlore slightly enriched in $\mathrm{Gd}_{2} \mathrm{O}_{3}$ and $\mathrm{HfO}_{2}$ relative to brannerite (Table
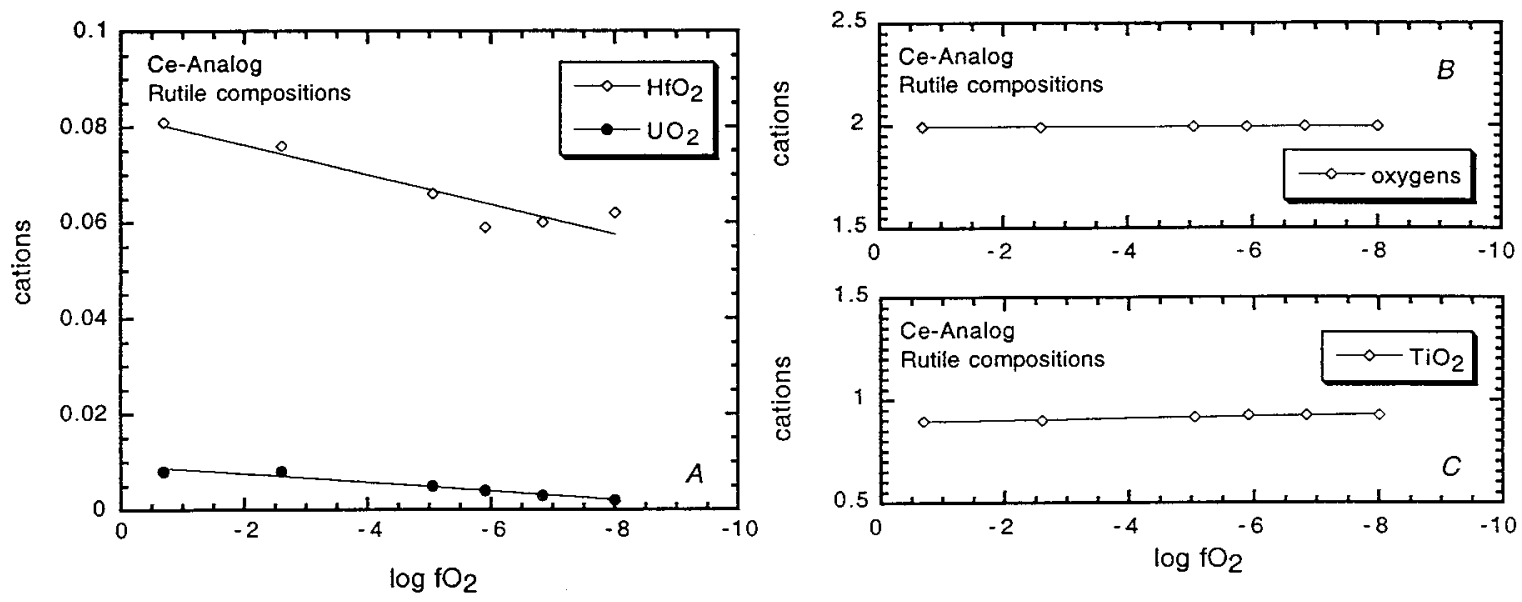

Figure 5. (A) Cation concentrations (normalized to 4 cations) in pyrochlores as a function of oxygen fugacity for the Ce-analog mixture. (B) Oxygen concentration assuming trivalent $\mathrm{Ce}$ and quadravalent $U$. (C) Ti concentration (normalized to 4 cations) in rutile as a function of oxygen fugacity for the Ce-analog mixture.

4). Brannerite contains approximately $50 \%$ more $\mathrm{UO}_{2}$ than the coexisting pyrochlore. Hafnolite is extremely enriched in $\mathrm{HfO}_{2}$ with respect to the other phases, and also contains 3-6 wt\% of $\mathrm{Ce}_{2} \mathrm{O}_{3}$, $\mathrm{Gd}_{2} \mathrm{O}_{3}$ and $\mathrm{UO}_{2}$. Perovskite contains as much as 23 wt $\% \mathrm{Ce}_{2} \mathrm{O}_{3}$; in $\mathrm{Pu}$-bearing materials, perovskite is, therefore, expected to incorporate $\mathrm{Pu}$.

The stoichiometry of the pyrochlores is consistent with a T-site that is essentially fully occupied by
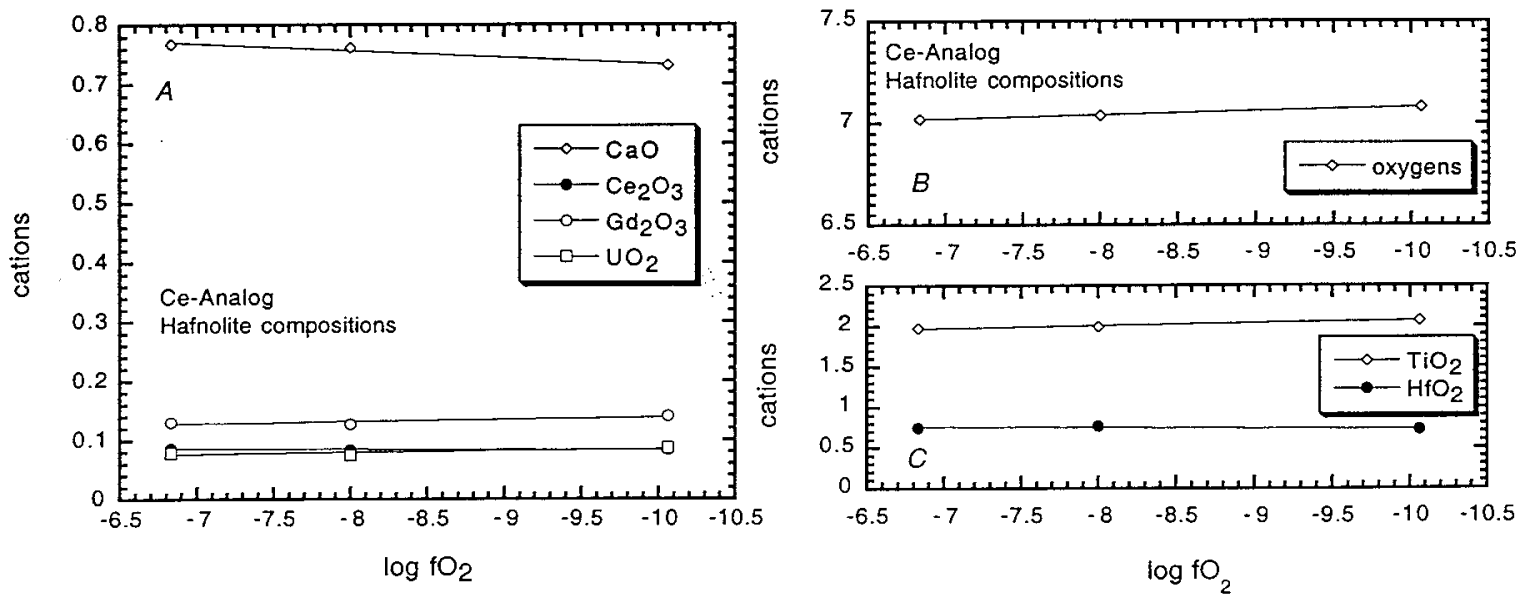

Figure 6. Cation concentrations (normalized to 1 cation) in perovskites as a function of oxygen fugacity for the Ce-analog mixture.

titanium -2 Ti cations per 4 total cations (Table 4). The Ti concentration of brannerite is also close 
to 2 Ti per 4 total cations indicating that the T-site in brannerites is essentially fully occupied by
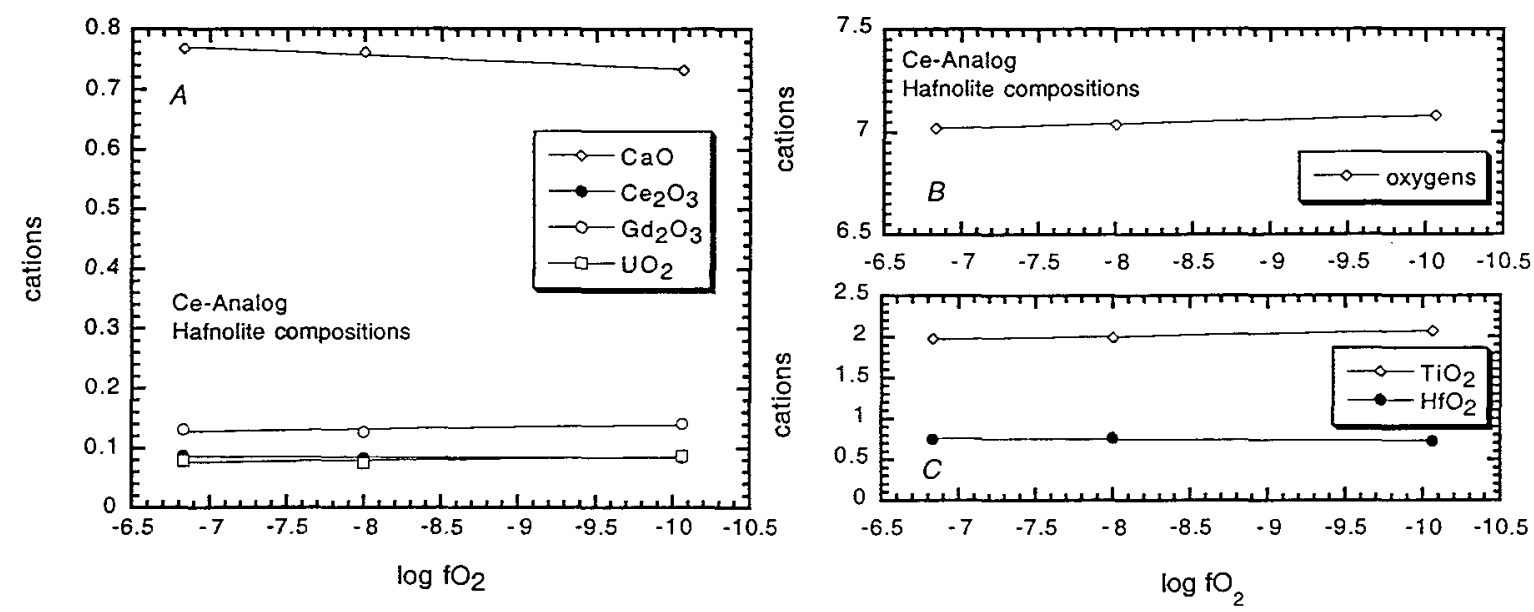

Figure 7. (A) Cation concentrations (normalized to 4 cations) in hafnolite as a function of oxygen fugacity for the Ce-analog mixture. (B) Oxygen concentration assuming trivalent $\mathrm{Ce}$ and quadravalent $\mathrm{U}$. (C) Ti and Hf concentration (normalized to 4 cations) in pyrochlores as a function of oxygen fugacity for the Ce-analog mixture.

titanium. This is also true of the hafnolites which typically have $\sim 2 \mathrm{Ti}$ cations per 4 total cations. However, the Ca content of hafnolite is always less than one indicating that the A-site in this phase is partially occupied by other elements.

The variation in pyrochlore chemistry is better displayed by plotting the cation concentrations (normalized to 4 cations) vs $\mathrm{fO}_{2}$ (Figure 3). The cation concentrations and the model oxygen stoichiometry vary smoothly with $\mathrm{fO}_{2}$, displaying no distinct discontinuity at the "hafnolite-in" boundary. The concentrations of $\mathrm{Hf}$ and $\mathrm{Gd}$ do not vary with respect to $\log f \mathrm{O}_{2}$. The concentrations of $\mathrm{Ti}$ and $\mathrm{U}$ in pyrochlore all increase with decreasing $\mathrm{fO}_{2}$. To compensate for the increases in the concentrations of $\mathrm{Ti}$ and $\mathrm{U}$, the number of both $\mathrm{Ca}$ and $\mathrm{Ce}$ cations per 4 cations decreases as a function of $\mathrm{fO}_{2}$. In fact, relative to their concentrations in air, the changes in $\mathrm{Ca}+\mathrm{Ce}$ and $\mathrm{Ti}+\mathrm{U}$ with decreasing $\mathrm{fO}_{2}$ are, within error, exactly compensated (Figure 4).

A model oxygen stoichiometry (total oxygen atoms per 4 cations) can also be calculated by assuming that uranium is present as $\mathrm{U}^{+4}$ and cerium as $\mathrm{Ce}^{+3}$. The number of oxygen atoms normalized to 4 cations increases from $\sim 6.74$ for samples sintered in air to close to the ideal stoichiometry of 7 oxygens normalized to 4 cations for samples sintered at $-\log f_{2} \sim 10$ (Figure 3b). This trend suggests that, for experiments equilibrated at higher $\mathrm{fO}_{2}$ greater than $-\log \mathrm{fO}_{2} \sim 10$, either uranium or cerium may be present in a higher oxidation site than assumed in the model.

The composition of rutile also shows a systematic change with $\mathrm{fO}_{2}$ (Figure $5 \mathrm{a}, \mathrm{b}$ ). The 
concentrations of $U$ and $\mathrm{Hf}$ both decrease as the processing conditions become more reducing. The model oxygen stoichiometry is relatively constant over this range, so it is difficult to determine whether the variation in rutile chemistry is a function of changes in oxidation state within the rutile

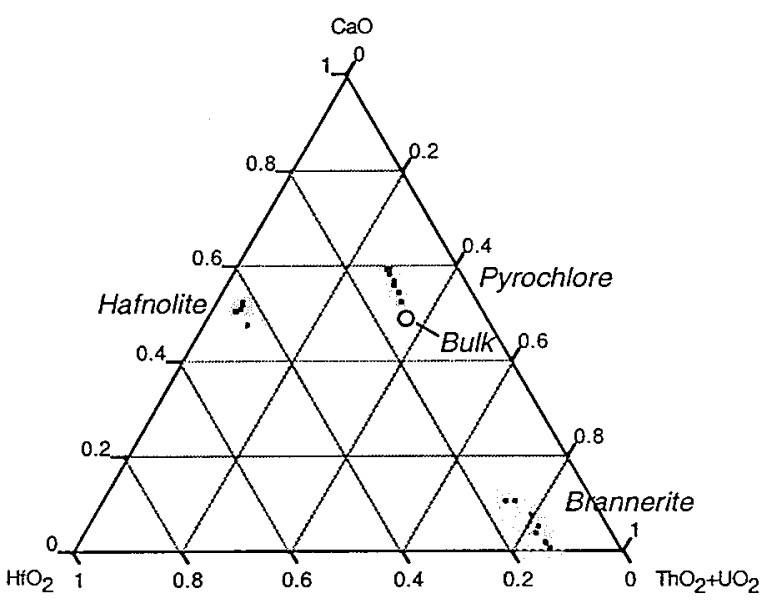

Figure 8. $\mathrm{CaO}-\mathrm{HfO}_{2}-\left(\mathrm{UO}_{2}+\mathrm{ThO}_{2}\right)$ from Thanalog materials sintered at $1350^{\circ} \mathrm{C}$. Pyrochlore and brannerite becomes richer in uranium with decreasing $\mathrm{fO}_{2}$. The bulk composition is given by the open circle. itself, or reflective of variations in the partition coefficients with $\mathrm{fO}_{2}$.

The major mineralogical change that takes place with decreased $\mathrm{fO}_{2}$ is the appearance of perovskite and hafnolite. Perovskite is enriched in calcium and the lanthanides, and the release of these elements from pyrochlore likely stabilizes this phase. The composition of perovskite shows little change with $\mathrm{fO}_{2}$ (Figures 2 and 6). The number of oxygens based on 2 cations (assuming $\mathrm{U}^{+4}$ and $\left(e^{+3}\right)$ is always greater than the 3 oxygens equivalent to the ideal stoichiometry. This is indicative of cation vacancies in the perovskite structure. Hafnolite strongly concentrates and is

stabilized by the presence of hafnium. Its appearance at lower $\mathrm{fO}_{2} \mathrm{~s}$ may be coupled with the decreasing concentrations of $\mathrm{Hf}$ in rutile, and the eventual disappearance of rutile in the lowest $\mathrm{fO}_{2}$ experiments. Like pyrochlore, the $\mathrm{Ca}$ content of hafnolite decreases somewhat with decreasing $\mathrm{fO}_{2}$ and appears to be coupled to increased U (Figure 7).

\subsection{Thorium-substituted analog}

The Th-substituted baseline composition is formulated as a mole-per-mole replacement of Ce by Th (Table 1) and allows us to evaluate the phase equilibria in an analog system in which uranium is the only element likely to occur in multiple valence states under the $\mathrm{T}-\mathrm{fO}_{2}$ range of these experiments. The major difference in the mineralogy between the Th- and Ce-substituted analogs is the ubiquity of brannerite and absence of perovskite in the Th-substituted formulation (Table 3). At $1350^{\circ} \mathrm{C}$ in air, the observed assemblage is pyrochlore-brannerite-rutile. Under conditions more reducing than air the assemblage is pyrochlore-brannerite-rutile \pm hafnolite. The compositions of coexisting phases are given in Table 5 and plotted on the $\mathrm{CaO}-\mathrm{HfO}_{2}-\left(\mathrm{UO}_{2}+\mathrm{ThO}_{2}\right)$ (Figure 8). The simplest interpretation of these results is that the addition of Th stabilizes brannerite, and by extension, if $\mathrm{Th}^{+4}$ is an analog for $\mathrm{U}^{+4}$, then brannerite should be stabilized under reducing conditions in Th-free formulations. The absence of perovskite can be explained by the absence of cerium which is strongly concentrated in, and hence, stabilizes perovskite. 
The pyrochlore compositions form a linear array parallel to the $\mathrm{CaO}-\left(\mathrm{ThO}_{2}+\mathrm{UO}_{2}\right)$ axis and, like the pyrochlores in the Ce-substituted assemblages, become more $\left(\mathrm{ThO}_{2}+\mathrm{UO}_{2}\right)$-rich with decreasing $\mathrm{fO}_{2}$ (Figure 8). Brannerite also forms and array parallel to the $\mathrm{CaO}-\left(\mathrm{ThO}_{2}+\mathrm{UO}_{2}\right)$ axis and, like the pyrochlores becomes richer in $\mathrm{UO}_{2}$ as $\mathrm{fO}_{2}$ decreases. The hafnolites form a relatively tight cluster, plotting in a position similar to those in the $\mathrm{Ce}$-analog experiments.

At the higher $\mathrm{fO}_{2} \mathrm{~S}_{2} \mathrm{UO}_{2}$ is equally distributed between brannerite and pyrochlore with both phases containing $\sim 20 \mathrm{wt} \% \mathrm{UO}_{2}$. Hafnolite is much poorer than either brannerite or pyrochlore in both $\mathrm{UO}_{2}$ (typically $\sim 4 \mathrm{wt} \%$ ) and $\mathrm{ThO}_{2}\left(1 \mathrm{wt} \%\right.$ ). Hafnolite does concentrate $\mathrm{HfO}_{2}$ containing roughly 4 and 5 times that in pyrochlore and brannerite, respectively.

In these pyrochlores, the Ca cation concentration per 4 cations is actually greater than one, and there is sufficient titanium to fill the T-site (Table 5). The T-site in brannerite can also be filled with titanium with $\sim 2$ Ti per 4 cations. Unlike the Ce-analog samples, the A-site in the Th-analog
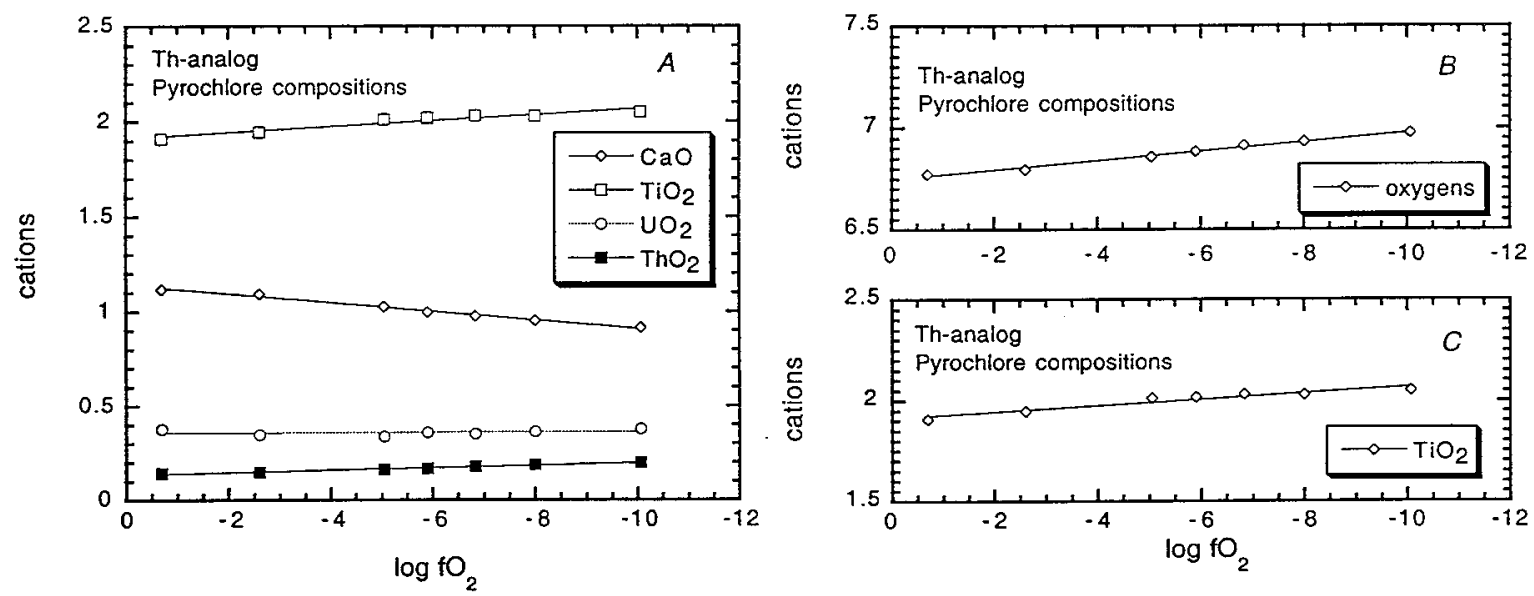

Figure 9. (A) Cation concentrations (normalized to 4 cations) in pyrochlore as a function of oxygen fugacity for the Th-analog mixture. (B) Oxygen concentration assuming trivalent $\mathrm{Ce}$ and quadravalent $U$. (C) Ti concentration (normalized to 4 cations) in pyrochlores as a function of oxygen fugacity for the Th-analog mixture.

hafnolites is essentially filled with calcium; $1 \mathrm{Ca}$ per 4 total cations. This may reflect the reduced lanthanide budget, allowing Gd to be totally accommodated on the B-site in the Th-analog hafnolites. 


\begin{tabular}{|c|c|c|c|c|c|c|c|c|c|c|c|c|c|c|}
\hline \multirow{10}{*}{$\begin{array}{l}\mathrm{Al}_{2} \mathrm{O}, \\
\mathrm{CaO} \\
\mathrm{TTO}_{2} \\
\mathrm{Gd}_{2} \mathrm{O}, \\
\mathrm{HrO}_{2} \\
\mathrm{ThO}_{2} \\
\mathrm{UO}, \\
\text { Total }\end{array}$} & \multicolumn{6}{|c|}{$\begin{array}{c}8-3 \\
\log f O_{2}=-0.69 \\
\end{array}$} & \multicolumn{8}{|c|}{$\begin{array}{c}8.4 \\
\log f O_{2}=-2.6\end{array}$} \\
\hline & $\begin{array}{r}\text { Pyrochlore } \\
\text { we\% } \\
\end{array}$ & $\begin{array}{r}6 \\
\text { sted der } \\
\end{array}$ & $\begin{array}{r}\text { Brannerice } \\
\text { wt\% } \\
\end{array}$ & $\begin{array}{r}6 \\
\text { std dev } \\
\end{array}$ & $\begin{array}{r}\text { Rutile } \\
\text { we\% } \\
\end{array}$ & sud dev & $\begin{array}{r}\begin{array}{r}\text { Pyrochlore } \\
\text { wit\% }\end{array} \\
\end{array}$ & $\begin{array}{r}7 \\
\text { std dev } \\
\end{array}$ & $\begin{array}{r}\text { Brannerite } \\
\text { wt\% } \\
\end{array}$ & $\begin{array}{r}6 \\
\text { std dev }\end{array}$ & $\begin{array}{r}\text { Hafnolite } \\
\text { wi\% } \\
\end{array}$ & $\begin{array}{r}3 \\
\text { std dev } \\
\end{array}$ & $\begin{array}{r}\text { Rutile } \\
\text { wt\% } \\
\end{array}$ & std dev \\
\hline & 0.00 & 0.00 & 0.04 & 0.10 & 0.30 & 0.01 & 0.05 & 0.02 & 0.20 & 0.01 & 1.29 & 0.07 & 0.30 & 0.15 \\
\hline & 14.03 & 0.05 & 1.36 & 0.07 & 0.08 & 0.02 & 13.47 & 0.21 & 1.23 & 0.07 & 11.57 & 0.38 & 0.05 & 0.01 \\
\hline & 34.14 & 0.10 & 39.60 & 0.23 & 79.10 & 0.77 & 34.19 & 0.60 & 38.53 & 0.54 & 36.08 & 0.93 & 80.95 & 0.72 \\
\hline & 8.85 & 0.20 & 5.87 & 0.16 & 0.15 & 0.04 & 8.72 & 0.22 & 5.49 & 0.39 & 4.65 & 0.38 & 0.00 & 0.00 \\
\hline & 10.91 & 0.16 & 7.59 & 0.39 & 19.15 & 0.53 & 11.08 & 0.18 & 6.53 & 1.27 & 39.45 & 1.84 & 16.38 & 0.22 \\
\hline & 8.48 & 0.31 & 22.14 & 0.77 & 0.06 & 0.03 & 8.64 & 0.16 & 21.60 & 1.51 & 1.09 & 0.01 & 0.00 & 0.00 \\
\hline & 23.00 & 0.29 & 21.70 & 0.61 & 8.44 & 0.03 & 20.72 & 0.50 & 22.49 & 0.97 & 4.32 & 0.49 & 1.05 & 0.09 \\
\hline & 99.40 & & 98.31 & $\cdot$ & 100.29 & & 96.87 & $\cdot$ & 96.05 & & 98.46 & $\cdot$ & 98.73 & \\
\hline Al & 0.000 & 0.000 & 0.003 & 0.008 & 0.005 & 0.000 & 0.004 & 0.002 & 0.016 & 0.001 & 0.107 & 0.003 & 0.006 & 0.002 \\
\hline a & 1.118 & 0.004 & 0.097 & 0.005 & 0.001 & 0.000 & 1.093 & 0.013 & 0.098 & 0.006 & 0.972 & 0.012 & 0.003 & 0.003 \\
\hline$\pi$ & 1.909 & 0.004 & 1.974 & 0.003 & 0.904 & 0.003 & 1.947 & 0.019 & 1.964 & 0.017 & 1.934 & 0.017 & 0.917 & 0.005 \\
\hline Gd & 0.218 & 0.005 & 0.129 & 0.004 & 0.001 & 0.000 & 0.219 & 0.007 & 0.123 & 0.009 & 0.109 & 0.005 & 0.000 & 0.000 \\
\hline Hf & 0.232 & 0.003 & 0.144 & 0.007 & 0.083 & 0.003 & 0.240 & 0.005 & 0.126 & 0.024 & 0.792 & 0.039 & 0.070 & 0.001 \\
\hline Th & 0.143 & 0.005 & 0.334 & 0.012 & 0.000 & 0.000 & 0.149 & 0.004 & 0.333 & 0.024 & 0.018 & 0.000 & 0.000 & 0.000 \\
\hline $\mathrm{U}$ & 0.380 & 0.004 & 0.320 & 0.010 & 0.005 & 0.000 & 0.349 & 0.008 & 0.339 & 0.015 & 0.069 & 0.005 & 0.004 & 0.001 \\
\hline Catatoms & 4.000 & ${ }^{\circ}$ & 3.000 & - & 1.000 & & 4.000 & 0.000 & 3.000 & 0.000 & 4.000 & 0.000 & 1.000 & 0.000 \\
\hline oxygen & 6.773 & 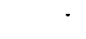 & 5.837 & $\cdot$ & 2.005 & & 6.796 & & 5.832 & & 6.921 & . & 1.994 & \\
\hline a & 0.000 & & 0.000 & & 0.000 & & 0.000 & & 0.000 & & 0.972 & & 0.000 & \\
\hline Gd & 0.000 & & 0.000 & & 0.000 & & 0.000 & & 0.000 & & 0.028 & & 0.000 & \\
\hline Th & 0.000 & & 0.000 & & 0.000 & & 0.000 & & 0.000 & & 0.000 & & 0.000 & \\
\hline Sum & 0.000 & & 0.000 & & 0.000 & & 0.000 & & 0.000 & & 1.000 & & 0.000 & \\
\hline Charge & 0.000 & & 0.000 & & 0.000 & & 0.000 & & 0.000 & & 2.028 & & 0.000 & \\
\hline a & 1.118 & & 0.097 & & 0.000 & & 1.093 & & 0.098 & & 0.000 & & 0.000 & \\
\hline Al & 0.000 & & 0.000 & & 0.000 & & 0.000 & & 0.000 & & $0.04 !$ & & 0.000 & \\
\hline Gd & 0.218 & & 0.129 & & 0.000 & & 0.219 & & 0.123 & & 0.080 & & 0.000 & \\
\hline $\mathrm{Hf}$ & 0.140 & & 0.120 & & 0.000 & & 0.190 & & 0.106 & & 0.792 & & 0.000 & \\
\hline Th & 0.143 & & 0.334 & & 0.000 & & 0.149 & & 0.333 & & 0.018 & & 0.000 & \\
\hline $\mathrm{U}$ & 0.380 & & 0.320 & & 0.000 & & 0.349 & & 0.339 & & 0.069 & & 0.000 & \\
\hline Sum & 2.000 & & 1.000 & & 0.000 & & 2.000 & & 1.000 & & 1.000 & & 0.000 & \\
\hline Charge & 6.000 & & 4.003 & & 0.000 & & 6.004 & & 4.016 & & 4.037 & & 0.000 & \\
\hline$\pi$ & 1.909 & & 1.974 & & 0.904 & & 1.947 & & 1.964 & & 1.934 & & 0.917 & \\
\hline Hif & 0.091 & & 0.023 & & 0.083 & & 0.049 & & 0.020 & & 0.000 & & 0.070 & \\
\hline $\mathrm{Al}$ & 0.000 & & 0.003 & & 0.005 & & 0.004 & & 0.016 & & 0.066 & & 0.006 & \\
\hline Sum & 2.000 & & 2.000 & & 0.993 & & 2.000 & & 2.000 & & 2.000 & & 0.993 & \\
\hline Charge & 8.000 & & 7.997 & & 3.966 & & 7.996 & & 7.984 & & 7.997 & & 3.967 & \\
\hline Uo, & 2.596 & & 2.509 & & 2.000 & & 2.586 & & 2.495 & & 3.148 & & 2.000 & \\
\hline Total Cations & 4.000 & & 3.000 & & 0.993 & & 4.000 & & 3.000 & & 4.000 & & 0.993 & \\
\hline $\begin{array}{l}\text { Model } \\
\text { Oxygens }\end{array}$ & 7.000 & & 6.000 & & 1.983 & & 7.000 & & 6.000 & & 7.000 & & 1.983 & \\
\hline
\end{tabular}




\begin{tabular}{|c|c|c|c|c|c|c|c|c|c|c|c|c|c|c|c|c|}
\hline \multirow{9}{*}{$\begin{array}{l}\mathrm{Al}_{2} \mathrm{O}_{3} \\
\mathrm{CaO} \\
\mathrm{TO}_{2} \\
\mathrm{Cd}_{2} \mathrm{O}, \\
\mathrm{HOO}_{2} \\
\mathrm{ThO}_{2} \\
\mathrm{UO}_{2}\end{array}$} & \multicolumn{8}{|c|}{$\begin{array}{c}8-5 \\
\log \mathrm{fO}_{2}=-5.05 \\
\end{array}$} & \multicolumn{8}{|c|}{$\begin{array}{c}8-6 \\
\log \mathrm{fO}_{2}=.5 .9 \\
\end{array}$} \\
\hline & $\begin{array}{r}\text { Pyrochlore } \\
\text { wt\% }\end{array}$ & $\begin{array}{r}6 \\
\text { std dev }\end{array}$ & $\begin{array}{r}\text { Brannerite } \\
\text { wt\% }\end{array}$ & $\begin{array}{r}5 \\
\text { std dev }\end{array}$ & $\begin{array}{r}\text { Hafnolite } \\
\text { we\% }\end{array}$ & $\begin{array}{r}4 \\
\text { std dev }\end{array}$ & $\begin{array}{r}\text { Rutile } \\
w 1 \% 8\end{array}$ & std dev & $\begin{array}{r}\text { Pyrochlore } \\
\text { wit\% }\end{array}$ & $\begin{array}{r}6 \\
\text { std dev } \\
\end{array}$ & $\begin{array}{r}\text { Brannenite } \\
w 1 \% \\
\end{array}$ & $\begin{array}{r}4 \\
\text { std dev }\end{array}$ & $\begin{array}{r}\text { Hafnolite } \\
w 1 \%\end{array}$ & $\begin{array}{r}3 \\
\text { std dev } \\
\end{array}$ & $\begin{array}{r}\text { Rutile } \\
\text { wt\% }\end{array}$ & $\begin{array}{r}3 \\
\text { std dev }\end{array}$ \\
\hline & 0.11 & 0.01 & 0.26 & 0.03 & 1.51 & 0.02 & 0.24 & 0.01 & 0.07 & 0.04 & 0.17 & 0.02 & 1.63 & 0.23 & 0.15 & 0.02 \\
\hline & 12.62 & 0.09 & 0.91 & 0.17 & 11.59 & 0.07 & 0.14 & 0.05 & 12.20 & 0.21 & 0.63 & 0.05 & 11.29 & 0.23 & 0.03 & 0.04 \\
\hline & 35.21 & 0.40 & 37.22 & 0.87 & 36.61 & 0.16 & 80.64 & 0.45 & 35.13 & 0.35 & 37.63 & 0.48 & 35.19 & 2.34 & 83.24 & 0.33 \\
\hline & 8.74 & 0.15 & 4.39 & 0.05 & 4.48 & 0.18 & 0.00 & 0.00 & 8.87 & 0.36 & 3.66 & 0.43 & 4.30 & 0.64 & 0.00 & 0.00 \\
\hline & 10.56 & 0.55 & 6.04 & 1.06 & 39.23 & 0.52 & 14.52 & 0.10 & 10.36 & 0.42 & 5.93 & 0.33 & 42.14 & 4.56 & 14.32 & 0.86 \\
\hline & 9.33 & 0.31 & 21.28 & 1.74 & 1.27 & 0.04 & 0.03 & 0.05 & 9.55 & 0.76 & 22.58 & 2.42 & 1.39 & 0.03 & 0.00 & 0.00 \\
\hline & 19.96 & 0.71 & 26.63 & 2.60 & 4.17 & 0.13 & 1.08 & 0.11 & 21.11 & 0.55 & 26.03 & 1.46 & 3.76 & 0.41 & 0.86 & 0.05 \\
\hline Total & 96.53 & & 96.72 & & 98.86 & & 96.64 & & 97.29 & . & 96.62 & $\cdot$ & 99.69 & $\cdot$ & 98.59 & \\
\hline Al & 0.010 & 0.001 & 0.021 & 0.003 & 0.124 & 0.004 & 0.004 & 0.000 & 0.006 & 0.003 & 0.014 & 0.001 & 0.134 & 0.012 & 0.002 & 0.001 \\
\hline$a$ & 1.028 & 0.007 & 0.074 & 0.015 & 0.956 & 0.009 & 0.002 & 0.001 & 0.999 & 0.008 & 0.052 & 0.004 & 0.941 & 0.007 & 0.001 & 0.001 \\
\hline$T_{i}$ & 2.013 & 0.016 & 1.938 & 0.024 & 1.944 & 0.017 & 0.926 & 0.002 & 2.019 & 0.007 & 1.971 & 0.012 & 1.903 & 0.072 & 0.933 & 0.003 \\
\hline $\mathrm{Gd}$ & 0.220 & 0.003 & 0.101 & 0.002 & 0.106 & 0.005 & 0.000 & 0.000 & 0.225 & 0.010 & 0.084 & 0.010 & 0.102 & 0.009 & 0.000 & 0.000 \\
\hline Hf & 0.229 & 0.012 & 0.119 & 0.020 & 0.778 & 0.021 & 0.064 & 0.001 & 0.226 & 0.008 & 0.118 & 0.006 & 0.835 & 0.087 & 0.062 & 0.003 \\
\hline Th & 0.162 & 0.005 & 0.335 & 0.024 & 0.023 & 0.006 & 0.000 & 0.000 & 0.166 & 0.013 & 0.358 & 0.040 & 0.022 & 0.001 & 0.000 & 0.000 \\
\hline$u$ & 0.338 & 0.011 & 0.411 & 0.044 & 0.068 & 0.006 & 0.004 & 0.000 & 0.359 & 0.010 & 0.403 & 0.020 & 0.061 & 0.005 & 0.003 & 0.000 \\
\hline \begin{tabular}{|l} 
Catatoms \\
\end{tabular} & 4.000 & 0.000 & 3.000 & 0.000 & 4.000 & 0.000 & 1.000 & 0.000 & 4.000 & 0.000 & 3.000 & 0.000 & 4.000 & 0.000 & 1.000 & 0.000 \\
\hline oxygen & 6.857 & & 5.865 & & 6.929 & - & 1.996 & & 6.885 & - & 5.899 & $\cdot$ & 6.940 & - & 1.998 & \\
\hline$C_{a}$ & 0.000 & & 0.000 & & 0.956 & & 0.000 & & 0.000 & & 0.000 & & 0.941 & & 0.000 & \\
\hline$G d$ & 0.000 & & 0.000 & & 0.044 & & 0.000 & & 0.000 & & 0.000 & & 0.059 & & 0.000 & \\
\hline $\mathrm{Th}$ & 0.000 & & 0.000 & & 0.000 & & 0.000 & & 0.000 & & 0.000 & & 0.000 & & 0.000 & \\
\hline \begin{tabular}{|l|} 
Sum \\
\end{tabular} & 0.000 & & 0.000 & & 1.000 & & 0.000 & & 0.000 & & 0.000 & & 1.000 & & 0.000 & \\
\hline Charge & 0.000 & & 0.000 & & 2.044 & & 0.000 & & 0.000 & & 0.000 & & 2.059 & & 0.000 & \\
\hline ca & 1.028 & & 0.074 & & 0.000 & & 0.000 & & 0.999 & & 0.052 & & 0.000 & & 0.000 & \\
\hline Al & 0.010 & & 0.000 & & 0.068 & & 0.000 & & 0.006 & & 0.000 & & 0.037 & & 0.000 & \\
\hline $\mathrm{Gd}$ & 0.220 & & 0.101 & & 0.062 & & 0.000 & & 0.225 & & 0.084 & & 0.044 & & 0.000 & \\
\hline $\mathrm{Hf}$ & 0.229 & & 0.079 & & 0.778 & & 0.000 & & 0.226 & & 0.102 & & 0.835 & & 0.000 & \\
\hline Th & 0.162 & & 0.335 & & 0.023 & & 0.000 & & 0.166 & & 0.358 & & 0.022 & & 0.000 & \\
\hline$u$ & 0.338 & & 0.411 & & 0.068 & & 0.000 & & 0.359 & & 0.403 & & 0.061 & & 0.000 & \\
\hline Sum & 1.987 & & 1.000 & & 1.000 & & 0.000 & & 1.981 & & 1.000 & & 1.000 & & 0.000 & \\
\hline Charge & 5.948 & & 4.021 & & 4.012 & & 0.000 & & 5.925 & & 4.014 & & 4.038 & & 0.000 & \\
\hline$\pi$ & 2.013 & & 1.938 & & 1.944 & & 0.926 & & 2.019 & & 1.971 & & 1.903 & & 0.933 & \\
\hline Hf & 0.000 & & 0.040 & & 0.000 & & 0.064 & & 0.000 & & 0.015 & & 0.000 & & 0.062 & \\
\hline $\mathrm{Al}$ & 0.000 & & 0.021 & & 0.056 & & 0.004 & & 0.000 & & 0.014 & & 0.097 & & 0.002 & \\
\hline Sum & 2.013 & & 2.000 & & 2.000 & & 0.994 & & 2.019 & & 2.000 & & 2.000 & & 0.996 & \\
\hline Charge & 8.052 & & 7.979 & & 7.997 & & 3.972 & & 8.075 & & 7.986 & & 7.997 & & 3.982 & \\
\hline uo. & 2.425 & & 2.330 & & 3.042 & & 2.000 & & 2.320 & & 2.250 & & 2.970 & & 2.000 & \\
\hline Total Cations & 4.000 & & 3.000 & & 4.000 & & 0.994 & & 4.000 & & 3.000 & & 4.000 & & 0.996 & \\
\hline $\begin{array}{l}\text { Model } \\
\text { Oxygens }\end{array}$ & 7.000 & & 6.000 & & 7.000 & & 1.986 & & 7.000 & & 6.000 & & 7.000 & & 1.991 & \\
\hline
\end{tabular}




\begin{tabular}{|c|c|c|c|c|c|c|c|c|c|c|c|c|c|c|}
\hline \multirow{9}{*}{$\begin{array}{l}\mathrm{Al}_{2} \mathrm{O} \\
\mathrm{CaO} \\
\mathrm{TOO} \\
\mathrm{Gd}_{2}, \mathrm{O}_{3} \\
\mathrm{HrO}_{2} \\
\mathrm{mO}_{2} \\
\mathrm{UO}_{2}\end{array}$} & \multicolumn{8}{|c|}{$\begin{array}{c}8-9 \\
\log f O_{2}=-6.83\end{array}$} & \multicolumn{6}{|c|}{$\begin{array}{c}8-7 \\
\log f O_{2}=-8 \\
\end{array}$} \\
\hline & $\begin{array}{r}\begin{array}{r}\text { Pyrochlore } \\
\text { wt\% }\end{array} \\
\end{array}$ & $\begin{array}{r}7 \\
\text { std dev }\end{array}$ & $\begin{array}{r}\text { Brannerite } \\
\text { w/\% }\end{array}$ & $\begin{array}{r}4 \\
\text { std der }\end{array}$ & $\begin{array}{r}\text { Hafnolite } \\
\text { wt\% }\end{array}$ & $\begin{array}{r}3 \\
\text { std dev }\end{array}$ & $\begin{array}{r}\text { Rutile } \\
\text { wt\% }\end{array}$ & std dev & $\begin{array}{r}\text { Pyrochlore } \\
\text { wt\% }\end{array}$ & $\begin{array}{r}8 \\
\text { std dev }\end{array}$ & $\begin{array}{r}\text { Brannerite } \\
w t \%\end{array}$ & $\begin{array}{r}4 \\
\text { std dev }\end{array}$ & $\begin{array}{r}\text { Rutile } \\
\text { wt\% }\end{array}$ & std dev \\
\hline & 0.09 & 0.01 & 0.19 & 0.02 & 1.92 & 0.02 & 0.24 & 0.02 & 0.11 & 0.01 & 0.17 & 0.01 & 0.25 & 0.01 \\
\hline & 11.78 & 0.23 & 0.50 & 0.04 & 11.23 & 0.22 & 0.01 & 0.02 & 11.48 & 0.13 & 0.23 & 0.01 & 0.00 & 0.00 \\
\hline & 34.92 & 0.31 & 37.74 & 0.34 & 36.47 & 0.56 & 82.80 & 0.40 & 34.84 & 0.21 & 37.14 & 0.25 & 83.38 & 0.30 \\
\hline & 8.30 & 0.14 & 3.15 & 0.18 & 4.91 & 0.34 & 0.00 & 0.00 & 8.47 & 0.20 & 2.41 & 0.05 & 0.00 & 0.00 \\
\hline & 10.82 & 0.28 & 6.52 & 0.78 & 38.68 & 1.04 & 14.58 & 0.81 & 10.69 & 0.16 & 6.30 & 0.34 & 14.06 & 0.16 \\
\hline & 10.18 & 0.24 & 22.18 & 0.81 & 1.66 & 0.07 & 0.00 & 0.00 & 10.70 & 0.45 & 23.10 & 1.60 & 0.00 & 0.00 \\
\hline & 20.50 & 0.45 & 27.13 & 0.18 & 4.13 & 0.10 & 0.44 & 0.00 & 21.18 & 0.72 & 28.09 & 1.21 & 0.24 & 0.07 \\
\hline Tocal & 96.58 & . & 97.40 & & 98.98 & . & 98.07 & & 97.46 & 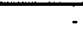 & 97.43 & 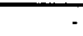 & 97.94 & \\
\hline Al & 0.008 & 0.001 & 0.016 & 0.001 & 0.164 & 0.009 & 0.004 & 0.000 & 0.010 & 0.001 & 0.014 & 0.001 & 0.004 & 0.000 \\
\hline $\mathrm{Ca}$ & 0.976 & 0.018 & 0.041 & 0.003 & 0.930 & 0.009 & 0.001 & 0.001 & 0.953 & 0.005 & 0.019 & 0.001 & 0.000 & 0.000 \\
\hline$T_{i}$ & $2.03 !$ & 0.011 & 1.972 & 0.012 & 1.912 & 0.041 & 0.932 & 0.002 & 2.030 & 0.017 & 1.971 & 0.012 & 0.935 & 0.001 \\
\hline Gd & 0.213 & 0.003 & 0.072 & 0.004 & 0.113 & 0.005 & 0.000 & 0.000 & 0.218 & 0.006 & 0.057 & 0.002 & 0.000 & 0.000 \\
\hline $\mathrm{Hf}$ & 0.239 & 0.007 & 0.129 & 0.016 & 0.792 & 0.030 & 0.062 & 0.002 & 0.236 & 0.002 & 0.127 & 0.007 & 0.060 & 0.001 \\
\hline Th & 0.179 & 0.004 & 0.351 & 0.012 & 0.026 & 0.002 & 0.000 & 0.000 & 0.189 & 0.007 & 0.371 & 0.024 & 0.000 & 0.000 \\
\hline $\mathrm{u}$ & 0.353 & 0.008 & 0.419 & 0.004 & 0.063 & 0.003 & 0.002 & 0.000 & 0.365 & 0.012 & 0.441 & 0.019 & 0.001 & 0.000 \\
\hline Catatoms & 4.000 & 0.000 & 3.000 & 0.000 & 4.000 & 0.000 & 1.000 & 0.000 & 4.000 & 0.000 & 3.000 & 0.000 & 1.000 & 0.000 \\
\hline oxygen & 6.913 & & 5.915 & & 6.931 & & 1.997 & & 6.933 & & 5.945 & . & 1.998 & \\
\hline $\mathrm{Ca}$ & 0.000 & & 0.000 & & 0.930 & & 0.000 & & 0.000 & & 0.000 & & 0.000 & \\
\hline Gd & 0.000 & & 0.000 & & 0.070 & & 0.000 & & 0.000 & & 0.000 & & 0,000 & \\
\hline $\mathrm{Th}$ & 0.000 & & 0.000 & & 0.000 & & 0.000 & & 0.000 & & 0.000 & & 0.000 & \\
\hline Sum & 0.000 & & 0.000 & & 1.000 & & 0.000 & & 0.000 & & 0.000 & & 0.000 & \\
\hline Charge & 0.000 & & 0.000 & & 2.070 & & 0.000 & & 0.000 & & 0.000 & & 0.000 & \\
\hline $\mathrm{ca}$ & 0.976 & & 0.041 & & 0.000 & & 0.000 & & 0.953 & & 0.019 & & 0.000 & \\
\hline $\mathrm{Al}$ & 0.008 & & 0.000 & & 0.075 & & 0.000 & & 0.010 & & 0.000 & & 0.000 & \\
\hline Gd & 0.213 & & 0.072 & & 0.043 & & 0.000 & & 0.218 & & 0.057 & & 0.000 & \\
\hline Hf & 0.239 & & 0.116 & & 0.792 & & 0.000 & & 0.236 & & 0.112 & & 0.000 & \\
\hline Th & 0.179 & & 0.351 & & 0.026 & & 0.000 & & 0.189 & & 0.371 & & 0.000 & \\
\hline $\mathrm{u}$ & 0.353 & & 0.419 & & 0.063 & & 0.000 & & 0.365 & & 0.441 & & 0.000 & \\
\hline Sum & 1.969 & & 1.000 & & 1.000 & & 0.000 & & 1.970 & & 1.000 & & 0.000 & \\
\hline Charge & 5.874 & & 4.016 & & 4.018 & & 0.000 & & 5.881 & & 4.014 & & 0.000 & \\
\hline$T_{i}$ & 2.031 & & 1.972 & & 1.912 & & 0.932 & & 2.030 & & 1.971 & & 0.935 & \\
\hline Hf & 0.000 & & 0.013 & & 0.000 & & 0.062 & & 0.000 & & 0.015 & & 0.060 & \\
\hline Al & 0.000 & & 0.016 & & 0.088 & & 0.004 & & 0.000 & & 0.014 & & 0.004 & \\
\hline Sum & 2.031 & & 2.000 & & 2.000 & & 0.998 & & 2.030 & & 2.000 & & 0.999 & \\
\hline Charge & 8.126 & & 7.984 & & 7.997 & & 3.987 & & 8.119 & & 7.986 & & 3.992 & \\
\hline uo, & 2.247 & & 2.203 & & 3.088 & & 2.000 & & 2.183 & & 2.124 & & 2.000 & \\
\hline Total Cations & 4.000 & & 3.000 & & 4.000 & & 0.998 & & 4.000 & & 3.000 & & 0.999 & \\
\hline $\begin{array}{l}\text { Model } \\
\text { Oxygens }\end{array}$ & 7.000 & & 6.000 & & 7.000 & & 1.993 & & 7.000 & & 6.000 & & 1.996 & \\
\hline
\end{tabular}




\begin{tabular}{|c|c|c|c|c|c|c|c|c|}
\hline \multirow{9}{*}{$\begin{array}{l}\mathrm{Al}_{2} \mathrm{O}_{3} \\
\mathrm{CaO} \\
\mathrm{TrO}_{2} \\
\mathrm{Gd}_{2} \mathrm{O}_{3} \\
\mathrm{HrO}_{2} \\
\mathrm{THO}_{2} \\
\mathrm{UO}_{2}\end{array}$} & \multicolumn{8}{|c|}{$\begin{array}{c}8.8 \\
\log f O_{2}=10.06 \\
\end{array}$} \\
\hline & $\begin{array}{r}\begin{array}{r}\text { Pyrochlore } \\
\text { wis }\end{array} \\
\end{array}$ & $\begin{array}{r}6 \\
\text { std dev } \\
\end{array}$ & $\begin{array}{r}\text { Brannerite } \\
\mathbf{w t \%} \\
\end{array}$ & $\begin{array}{r}3 \\
\text { std der } \\
\end{array}$ & $\begin{array}{r}\text { Hafnolite } \\
\text { wit\% }\end{array}$ & $\begin{array}{r}4 \\
\text { stdd dev }\end{array}$ & $\begin{array}{r}\text { Rutile } \\
\text { wiक }\end{array}$ & std dev \\
\hline & 0.10 & 0.01 & 0.09 & 0.01 & 1.84 & 0.42 & 0.36 & 0.05 \\
\hline & 10.85 & 0.10 & 0.14 & 0.02 & 10.09 & 0.20 & 0.03 & 0.03 \\
\hline & 34.68 & 0.24 & 36.85 & 0.21 & 38.00 & 0.21 & 82.86 & 0.26 \\
\hline & 8.17 & 0.28 & 1.46 & 0.07 & 5.38 & 0.15 & 0.00 & 0.00 \\
\hline & 10.51 & 0.19 & 6.14 & 0.31 & 34.92 & 0.75 & 14.58 & 0.55 \\
\hline & 11.04 & 0.27 & 23.66 & 1.92 & 2.73 & 0.28 & 0.00 & 0.00 \\
\hline & 21.66 & 0.43 & 29.44 & 1.27 & 5.03 & 0.28 & 0.14 & 0.04 \\
\hline \begin{tabular}{|l} 
Total \\
\end{tabular} & 97.02 & & 97.78 & - & 98.00 & & 97.97 & \\
\hline$A \mid$ & 0.009 & 0.001 & 0.008 & 0.001 & 0.157 & 0.035 & 0.006 & 0.001 \\
\hline $\mathrm{Ca}$ & 0.914 & 0.006 & 0.012 & 0.002 & 0.786 & 0.017 & 0.000 & 0.000 \\
\hline$\pi$ & 2.051 & 0.008 & 1.972 & 0.010 & 2.077 & 0.017 & 0.931 & 0.001 \\
\hline $\mathrm{Gd}$ & 0.213 & 0.007 & 0.034 & 0.002 & 0.130 & 0.003 & 0.000 & 0.000 \\
\hline $\mathrm{Hf}$ & 0.236 & 0.005 & 0.125 & 0.006 & 0.724 & 0.016 & 0.062 & 0.002 \\
\hline Th & 0.198 & 0.005 & 0.383 & 0.031 & 0.045 & 0.004 & 0.000 & 0.000 \\
\hline $\mathrm{u}$ & 0.379 & 0.006 & 0.466 & 0.020 & 0.081 & 0.004 & 0.000 & 0.000 \\
\hline Catatoms & 4.000 & 0.000 & 3.000 & 0.000 & 4.000 & - & 1.000 & 0.000 \\
\hline oxygen & 6.975 & & 5.967 & . & 7.071 & - & 1.996 & \\
\hline $\mathrm{Ca}$ & 0.000 & & 0.000 & & 0.786 & & 0.000 & \\
\hline Gd & 0.000 & & 0.000 & & 0.130 & & 0.000 & \\
\hline $\mathrm{Th}$ & 0.000 & & 0.000 & & 0.000 & & 0.000 & \\
\hline Sum & 0.000 & & 0.000 & & 0.915 & & 0.000 & \\
\hline Charge & 0.000 & & 0.000 & & 1.960 & & 0.000 & \\
\hline a & 0.914 & & 0.012 & & 0.000 & & 0.000 & \\
\hline $\mathrm{Al}$ & 0.009 & & 0.000 & & 0.157 & & 0.000 & \\
\hline $\mathrm{Gd}$ & 0.213 & & 0.034 & & 0.000 & & 0.000 & \\
\hline $\mathrm{HF}$ & 0.236 & & 0.104 & & 0.724 & & 0.000 & \\
\hline Th & 0.198 & & 0.383 & & 0.045 & & 0.000 & \\
\hline $\mathrm{U}$ & 0.379 & & 0.466 & & 0.081 & & 0.000 & \\
\hline Sum & 1.949 & & 1.000 & & 1.008 & & 0.000 & \\
\hline Charge & 5.796 & & 4.008 & & 3.875 & & 0.000 & \\
\hline$\pi$ & 2.051 & & 1.972 & & 2.077 & & 0.931 & \\
\hline Hf & 0.000 & & 0.020 & & 0.000 & & 0.062 & \\
\hline Al & 0.000 & & 0.008 & & 0.000 & & 0.006 & \\
\hline Sum & 2.051 & & 2.000 & & 2.077 & & 0.999 & \\
\hline Charge & 8.204 & & 7.992 & & 8.306 & & 3.990 & \\
\hline UO, & 2.067 & & 2.071 & & 2.000 & & 2.000 & \\
\hline Total Cations & 4.000 & & 3.000 & & 4.000 & & 0.999 & \\
\hline $\begin{array}{l}\text { Model } \\
\text { Oxygens }\end{array}$ & 7.000 & & 6.000 & & 7.071 & & 1.995 & \\
\hline
\end{tabular}


The composition of pyrochlore changes systematically with $\mathrm{fO}_{2}$ and displays no composition discontinuities at the "hafnolite-in" boundaries (Figure 9); the regression coefficients with respect to $\log \mathrm{fO}_{2}$ are given in Table 8. The Hf and Gd concentrations are essentially constant (at the $2 \delta$

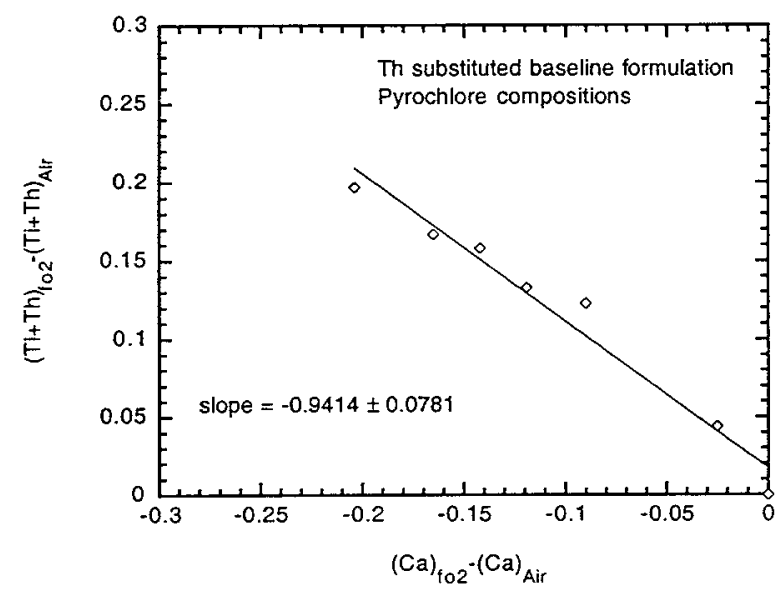

Figure 10. The variation in $\mathrm{Ti}+\mathrm{Th}$ in pyrochlores sintered under reducing conditions relative to those sintered in air as a function of the change in $\mathrm{Ca}$ in runs sintered under reducing conditions relative to those sintered in air. level) for all runs, but the $\mathrm{Ca}$ content of pyrochlore decreases with $\mathrm{fO}_{2}$ in much the same way as it did in the Ce-analog experiments. However, unlike the Ce-analog the concentration of uranium is constant with respect to changing $\mathrm{fO}_{2}$. The decrease in $\mathrm{Ca}$ is compensated by $\mathrm{Ti}$ and $\mathrm{Th}$ which both increase with decreasing $\mathrm{fO}_{2}$ (Figure 10). The number of formula oxygen atoms per 4 cations in pyrochlore also increases with decreasing $\mathrm{fO}_{2}$ as it did in the Ce-analog (Figure 9b). Since there is no cerium in these samples, the only valence change possible for accommodating this non-stoichiometry is $U^{+4} \leftrightarrow U^{+5,+6}$.

\section{Brannerite compositions also vary} systematically and continuously with decreasing $\mathrm{fO}_{2}$, with the concentrations of $\mathrm{Hf}$ and $\mathrm{Ca}$ decreasing and $\mathrm{U}$ and $\mathrm{Th}$ concentrations and the model oxygen stoichiometry increasing (Figure 11). The increasing concentrations of $U$ at lower $\mathrm{fO}_{2} \mathrm{~s}$ is consistent with the stabilization of brannerite under more reducing conditions.
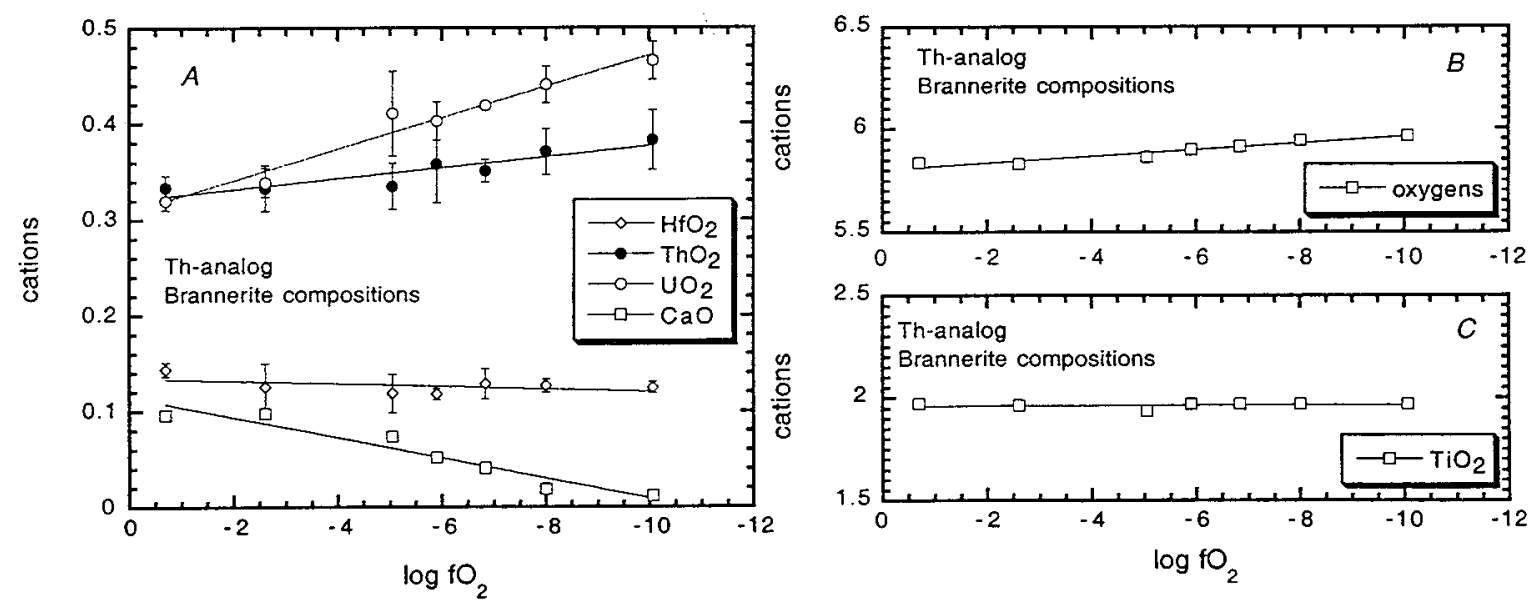

Figure 11. (A) Cation concentrations (normalized to 4 cations) in brannerite as a function of oxygen fugacity for the Th-analog mixture. (B) Oxygen concentration assuming quadravalent $U$. (C) $\mathrm{Ti}$ concentration (normalized to 4 cations) in pyrochlores as a function of oxygen fugacity for the Th-analog mixture. 
The range of hafnolite compositions is smaller than that observed for brannerite and pyrochlore, but like that in the other phases varies systematically and continuously with $\mathrm{fO}_{2}$ (Figure 12). Ti, $\mathrm{Hf}$ and $\mathrm{U}$ are all essentially constant with changing $\mathrm{fO}_{2}$. The major chemical variations are in $\mathrm{Th}$ and $\mathrm{Gd}$ which increase (Th more strongly than $\mathrm{Gd}$ ) and in $\mathrm{Ca}$ which decreases. For the run conducted in air, the " $\mathrm{A}$ " site in hafnolite $\left(\mathrm{ABT}_{2} \mathrm{O}_{7}\right)$ is essentially filled with calcium $(\sim 0.97 \mathrm{Ca})$ and decreases with $\mathrm{fO}_{2}$. If Th preferentially enters the "B" site, then the compositional trends
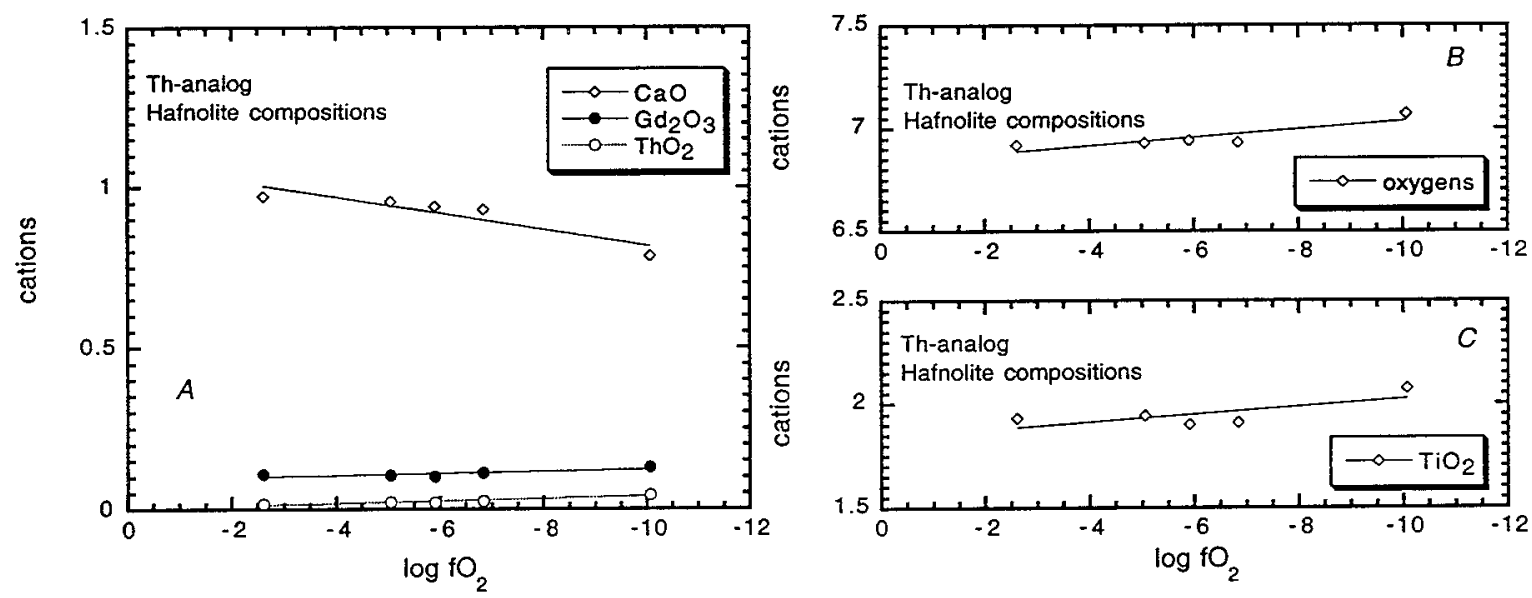

Figure 12. (A) Cation concentrations (normalized to 4 cations) in hafnolite as a function of oxygen fugacity for the Th-analog mixture. (B) Oxygen concentration assuming quadravalent $U$. (C) $\mathrm{Ti}$ concentration (normalized to 4 cations) in hafnolite as a function of oxygen fugacity for the Th-analog mixture

observed suggest that $\mathrm{Gd}$ is also accommodated on the $\mathrm{B}$-site at high $\mathrm{fO}_{2}$, and is displaced by increased Th concentration, moving to the A-site at lower $\mathrm{fO}_{2}$. Otherwise, the hafnolites approach ideal $\mathrm{ABT}_{2} \mathrm{O}_{7}$ stoichiometry with charge excess on the $\mathrm{A}$ and $\mathrm{B}$ sites compensating for charge deficiency on the T-site (Table 5). The concentration of uranium in the hafnolites is sufficiently small as to have negligible effect on this conclusion. 
Another feature of the hafnolite chemistry that should be noted is the presence of $\mathrm{Al}_{2} \mathrm{O}_{3}$ that reaches as high as $1.9 \mathrm{wt} \%$ in one experiment (8/9, Table 5). No $\mathrm{Al}_{2} \mathrm{O}_{3}$ was specifically added to
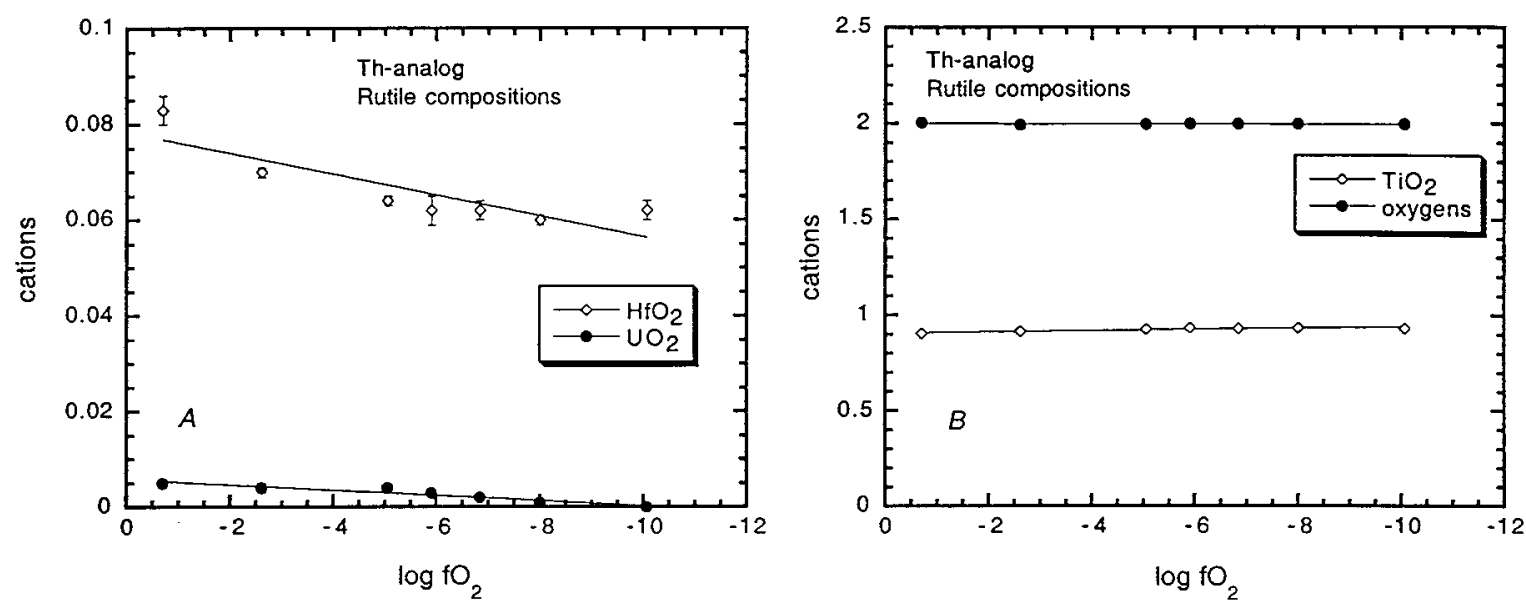

Figure 13. (A) Cation concentrations (normalized to 1 cation) in rutile as a function of oxygen fugacity for the Th-analog mixture. (B) Oxygen and titanium concentration (normalized to 1 cation) assuming quadravalent $\mathrm{U}$.

the formulation, so it is probable that it is present as a processing contaminant added during grinding in an alumina mortar. Nevertheless, it has been previously observed that aluminum tends to stabilize hafnolite, and the presence of hafnolite in these runs may be partially attributed to this (Ryerson et al., 2000).

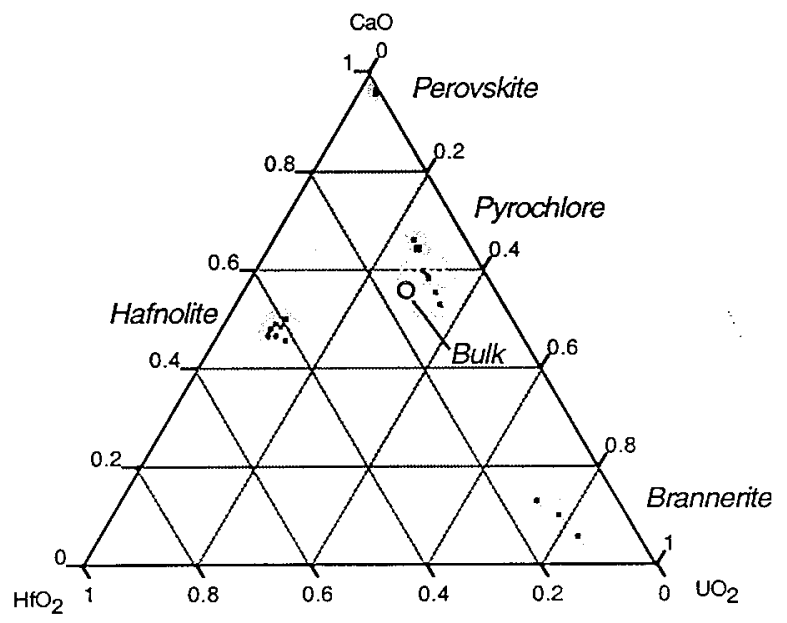

Figure 14. $\mathrm{CaO}-\mathrm{HfO}_{2}-\mathrm{UO}_{2}$ diagram showing the compositions of perovskite, pyrochlore, hafnolite and brannerites from $\mathrm{Ce} / \mathrm{Al}$-analog materials sintered at $1350^{\circ} \mathrm{C}$. Pyrochlores become richer in uranium with decreasing $\mathrm{fO}_{2}$. The bulk composition is given by the open circle.
Rutiles from the Th-analog experiments are, within error, stoichiometric (Table 7). The $\mathrm{UO}_{2}$ concentrations vary from $\sim 0.2$ to $\sim 1.5 \mathrm{wt} \%$, but $\mathrm{ThO}_{2}$ concentrations are always close to the level of detection. The trends in chemistry are qualitatively identical to those observed in the $\mathrm{Ce}$-analog; $\mathrm{Hf}$ and $\mathrm{U}$ both decrease with $\mathrm{fO}_{2}$, correlated with an increase in Ti (Figure 13). The release of $\mathrm{Hf}$ and $\mathrm{U}$ from rutile is in some part responsible for the stabilization of hafnolite, and the increased $U$ in brannerite (Figure 11), respectively. 


\subsection{Cerium-substituted analog with $10 \mathrm{wt} \% \mathrm{Al}_{2} \mathrm{O}_{3}$}

The phase assemblages in the cerium-substituted analog with $10 \mathrm{wt} \% \mathrm{Al}_{2} \mathrm{O}_{3}$ (hereafter referred to as the $\mathrm{Ce} / \mathrm{Al}$ analog) bear some similarity to those in the Ce-analog runs. However, the effects
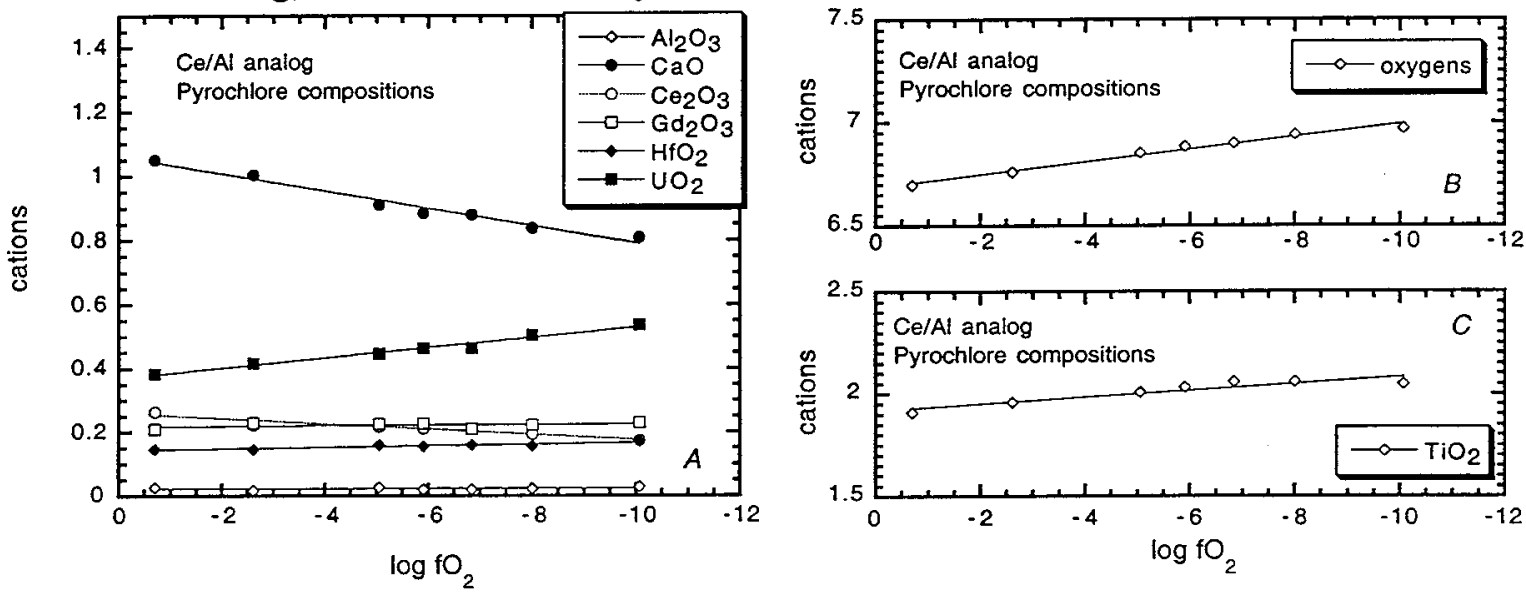

Figure 15. (A) Cation concentrations (normalized to 4 cations) in pyrochlore as a function of oxygen fugacity for the Ce/Al-analog mixture. (B) Oxygen concentration assuming trivalent $\mathrm{Ce}$ and quadravalent $U$. (C) Ti concentration (normalized to 4 cations) in pyrochlore as a function of oxygen fugacity for the Ce/Al-analog mixture.

of $\mathrm{Al}_{2} \mathrm{O}_{3}$ addition are observed in both the stabilization of hafnolite (with typical $\mathrm{Al}_{2} \mathrm{O}_{3}$ concentrations are 4-6 wt\%) and in the presence of Al-rich accessory phases (Table 3). At high $\mathrm{fO}_{2} \mathrm{Al}$-psuedobrookite (nominally $\mathrm{Al}_{2} \mathrm{TiO}_{5}$ ) is the stable Al-rich phase. As $\mathrm{fO}_{2}$ is decreased the $\mathrm{Al}$-rich phase becomes a calcium-titanoaluminate with the nominal formula $\mathrm{AT}_{11} \mathrm{O}_{19}$ where the
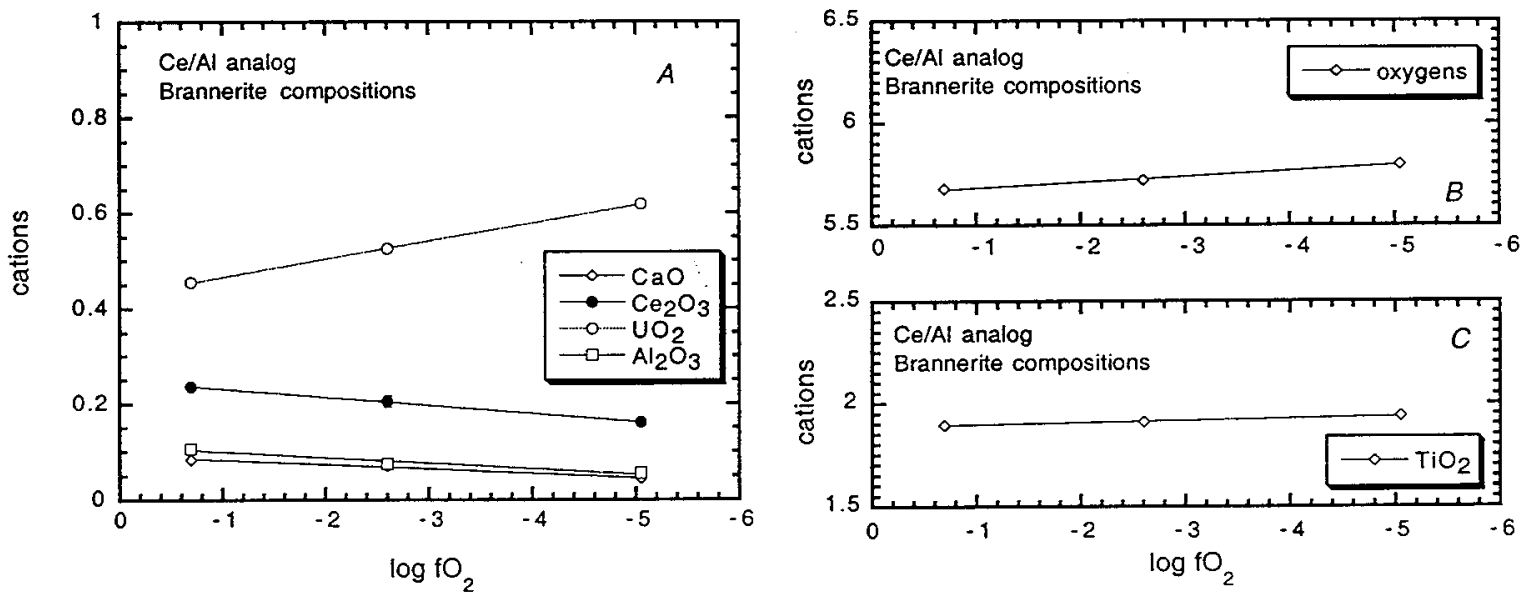

Figure 16. (A) Cation concentrations (normalized to 4 cations) in brannerite as a function of oxygen fugacity for the $\mathrm{Ce} / \mathrm{Al}$-analog mixture. (B) Oxygen concentration assuming trivalent $\mathrm{Ce}$ and quadravalent $U$. (C) Ti concentration (normalized to 4 cations) in brannerite as a function of oxygen fugacity for the Ce/Al-analog mixture. 
"A" site is filled with $\mathrm{Ca}$ and $\mathrm{Ce}$ and the $\mathrm{T}$-site with $\mathrm{Al}$ ( $\sim 9$ cations) and $\mathrm{Ti}\left(\sim 2\right.$ cations). At $\mathrm{fO}_{2} \mathrm{~s}$ more oxidizing than $\log \mathrm{fO}_{2}=-5.05$ brannerite is present and at $\mathrm{fO}_{2} \mathrm{~s}$ more reducing than $\log f \mathrm{O}_{2}=-$ 6.83 perovskite is present (Table 3 ).

The pyrochlores form an array parallel to the $\mathrm{CaO}-\mathrm{UO}_{2}$ join on the $\mathrm{CaO}-\mathrm{HfO}_{2}-\mathrm{UO}_{2}$ ternary (Figure 14) becoming enriched in $\mathrm{UO}_{2}$ as $\mathrm{fO}_{2}$ decreases, as in the Ce- and Th-analog experiments. The variation in chemistry is also similar to that observed in the other analog materials (Table 6). As $\mathrm{fO}_{2}$ decreases the $\mathrm{Ca}$ and $\mathrm{Ce}$ contents of the pyrochlores decrease, and the $\mathrm{U}$ and $\mathrm{Ti}$ concentrations increase (Figure 15). Assuming $\mathrm{Ce}^{+3}$ and $\mathrm{U}^{+4}$, the total oxygen atom contents increases to close to the ideal content with decreasing $\mathrm{fO}_{2}$ (Figure 15b).

Brannerite plots at a constant $\mathrm{Ca} / \mathrm{Hf}$ ratio on the $\mathrm{CaO}-\mathrm{HfO}_{2}-\mathrm{UO}_{2}$ ternary (Figure 14) becoming richer in $\mathrm{UO}_{2}$ as $\mathrm{fO}_{2}$ decreases (Figure 16). Hafnolite forms a relatively tight cluster on the $\mathrm{CaO}-$ $\mathrm{HfO}_{2}-\mathrm{UO}_{2}$ temary (Figure 14), and are close to the ideal 4 cations to 6 oxygen stoichiometry (Table 6). The chemistry does show systematic variations with $\mathrm{fO}_{2}$, however, as $\mathrm{Ca}$ and $\mathrm{Hf}$
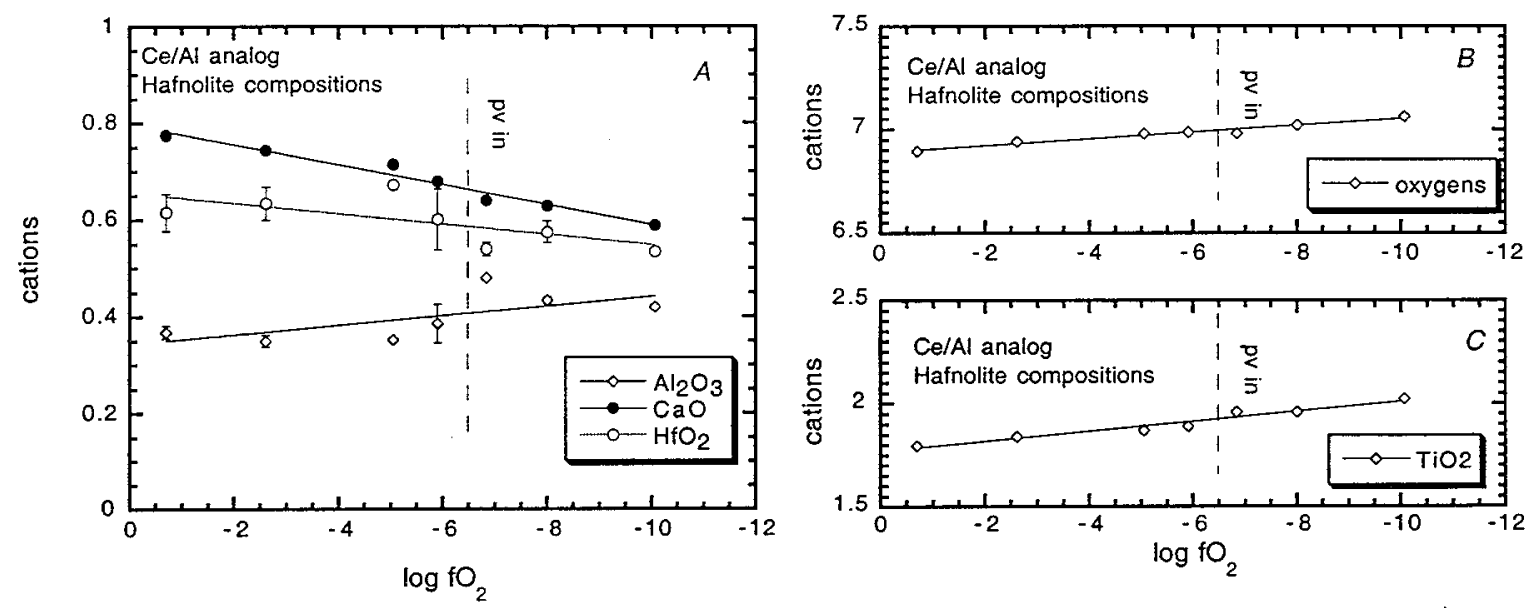

Figure 17. (A) Cation concentrations (normalized to 4 cations) in hafnolite as a function of oxygen fugacity for the Ce/Al-analog mixture. (B) Oxygen concentration assuming trivalent $\mathrm{Ce}$ and quadravalent $U$. (C) Ti concentration (normalized to 4 cations) in hafnolite as a function of oxygen fugacity for the Ce/Al-analog mixture.

decrease with decreasing $\mathrm{fO}_{2}$ and $\mathrm{Al}$ and Ti increase (Figure 17). Perovskite is strongly enriched in cerium (up to $23 \mathrm{wt} \% \mathrm{Ce}_{2} \mathrm{O}_{3}$ ) and displays limited compositional variation (Figure 14). Oxygen in excess of the ideal 3 oxygens normalized to 2 cations are observed (Table 6), indicating the existence of cation vacancies in perovskite. 
Psuedobrookite is observed in the run sintered in air, and is essentially free of all elements other than $\mathrm{Al}$ and $\mathrm{Ti}$ (7-3, Table 7). The calcium-titanoaluminate, on the otherhand, does incorporate cerium (typical concentrations are $\sim 7 \mathrm{wt} \% \mathrm{Ce}_{2} \mathrm{O}_{3}$ ), and to a lesser extent gadolinium, hafnium and uranium. If cerium is, indeed, a good analog for plutonium, we would expect this calcium-aluminotitanate phase to incorporate $\mathrm{Pu}$ in the actual Pu-bearing baseline formulation fabricated under these conditions.

As in the Ce-analog, the major compositional variations observed are the decreases in $\mathrm{Ca}$ and $\mathrm{Ce}$ in pyrochlore, brannerite and hafnolite under more reducing conditions. The progressive release of these components can be seen in the changing phase assemblage. The first manifestation is the reaction of $\mathrm{Ca}$ and $\mathrm{Ce}$ with psuedobrookite to yield the calcium-titanoaluminate phase that incorporates both of these components. As conditions become more reducing $\mathrm{Ca}$ and $\mathrm{Ce}$ react with, and destabilize brannerite producing perovskite and progressively more $\mathrm{UO}_{2}$-rich pyrochlore. 
26

\begin{tabular}{|c|c|c|c|c|c|c|c|c|c|c|c|c|c|c|c|c|c|c|}
\hline \multirow{9}{*}{$\begin{array}{l}\mathrm{Al}_{2} \mathrm{O}, \\
\mathrm{CaO} \\
\mathrm{TOO}_{2} \\
\mathrm{Ce}_{2} \mathrm{O}, \\
\mathrm{Cd}_{2} \mathrm{O}, \\
\mathrm{HrO}_{2} \\
\mathrm{UO}_{2}\end{array}$} & \multicolumn{8}{|c|}{$\begin{array}{c}7.3 \\
\log \rho O_{z}=-0.69\end{array}$} & \multicolumn{10}{|c|}{$\begin{array}{c}7.4 \\
\log \rho_{2}=-2.6\end{array}$} \\
\hline & $\begin{array}{r}\text { Pyrochlore } \\
\text { wit\% }\end{array}$ & $\begin{array}{r}4 \\
\text { sid dev }\end{array}$ & $\begin{array}{r}\text { Brannerite } \\
\text { wt\% }\end{array}$ & $\begin{array}{r}3 \\
\text { std dev }\end{array}$ & $\begin{array}{r}\text { Hafnolite } \\
w t \%\end{array}$ & $\begin{array}{r}3 \\
\text { std dev }\end{array}$ & $\begin{array}{r}\text { Psb } \\
w t \%\end{array}$ & $\begin{array}{r}2 \\
\text { std dev }\end{array}$ & $\begin{array}{r}\text { Pyrochlore } \\
\text { wt\% }\end{array}$ & $\begin{array}{r}6 \\
\text { std dev }\end{array}$ & $\begin{array}{r}\text { Hafnolite } \\
\text { wt\% }\end{array}$ & $\begin{array}{r}5 \\
\text { std dev }\end{array}$ & $\begin{array}{r}\text { Brannerite } \\
\text { wr\% }\end{array}$ & $\begin{array}{r}5 \\
\text { std dev }\end{array}$ & $\begin{array}{l}\text { CTA } \\
\text { w1\% }\end{array}$ & $\begin{array}{r}4 \\
\text { std dev }\end{array}$ & $\begin{array}{r}\text { Rutile } \\
\text { wo\% }\end{array}$ & std der \\
\hline & 0.32 & 0.01 & 1.44 & 0.05 & 4.35 & 0.18 & 42.09 & 2.11 & 0.20 & 0.04 & 4.08 & 0.16 & 0.98 & 0.01 & 65.59 & 10.56 & 1.12 & 0.08 \\
\hline & 13.41 & 0.11 & 1.25 & 0.05 & 10.13 & 0.54 & 0.00 & 0.00 & 12.49 & 0.16 & 9.52 & 0.18 & 1.02 & 0.04 & 3.28 & 0.90 & 0.09 & 0.00 \\
\hline & 34.77 & 0.35 & 40.27 & 0.09 & 33.43 & 0.11 & 0.00 & 0.00 & 34.73 & 0.24 & 33.61 & 0.19 & 39.21 & 0.18 & 22.28 & 5.98 & 83.24 & 0.68 \\
\hline & 9.89 & 0.35 & 10.28 & 0.18 & 4.25 & 0.56 & 0.00 & 0.00 & 8.11 & 0.24 & 3.58 & 0.24 & 8.65 & 0.51 & 7.86 & 2.14 & 0.11 & 0.01 \\
\hline & 8.72 & 0.22 & 6.30 & 0.24 & 7.40 & 0.40 & 0.00 & 0.00 & 9.26 & 0.28 & 7.49 & 0.16 & 6.10 & 0.21 & 0.78 & 0.26 & 0.04 & 0.05 \\
\hline & 7.10 & 0.07 & 5.08 & 0.13 & 30.43 & 2.36 & 98.85 & 0.33 & 6.83 & 0.12 & 30.45 & 1.67 & 4.32 & 0.09 & 0.88 & 0.30 & 11.65 & 0.35 \\
\hline & 23.62 & 0.72 & 32.68 & 0.26 & 9.55 & 1.41 & 0.00 & 0.00 & 24.96 & 0.34 & 9.41 & 0.96 & 36.46 & 0.53 & 0.38 & 0.51 & 2.87 & 0.04 \\
\hline Total & 97.83 & - & 97.30 & $\cdot$ & 99.52 & 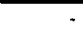 & 0.00 & 0.00 & 96.58 & - & 98.14 & - & 96.75 & 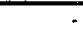 & 101.05 & 2.38 & 99.13 & 0.94 \\
\hline AI & 0.028 & 0.001 & 0.107 & 0.004 & 0.368 & 0.013 & 2.036 & 0.053 & 0.018 & 0.004 & 0.350 & 0.012 & 0.075 & 0.001 & 9.141 & 0.913 & 0.018 & 0.002 \\
\hline $\mathrm{Ca}$ & 1.051 & 0.005 & 0.084 & 0.003 & 0.775 & 0.025 & 0.001 & 0.001 & 1.005 & 0.008 & 0.744 & 0.014 & 0.071 & 0.003 & 0.423 & 0.136 & 0.002 & 0.001 \\
\hline$\pi$ & 1.912 & 0.013 & 1.897 & 0.002 & 1.799 & 0.006 & 0.964 & 0.053 & 1.961 & 0.007 & 1.843 & 0.008 & 1.912 & 0.008 & 2.018 & 0.635 & 0.920 & 0.001 \\
\hline $\mathrm{Ce}_{\mathrm{C}}$ & 0.265 & 0.008 & 0.236 & 0.003 & 0.112 & 0.010 & 0.000 & 0.000 & 0.223 & 0.007 & 0.096 & 0.007 & 0.205 & 0.012 & 0.347 & 0.111 & 0.001 & 0.000 \\
\hline Gd & 0.211 & 0.004 & 0.131 & 0.005 & 0.175 & 0.006 & 0.000 & 0.000 & 0.231 & 0.006 & 0.181 & 0.003 & 0.131 & 0.004 & 0.031 & 0.012 & 0.000 & 0.001 \\
\hline $\mathrm{Hr}$ & 0.148 & 0.002 & 0.091 & 0.002 & 0.616 & 0.039 & 0.000 & 0.000 & 0.146 & 0.003 & 0.634 & 0.034 & 0.080 & 0.002 & 0.030 & 0.011 & 0.049 & 0.001 \\
\hline$u$ & 0.384 & 0.013 & 0.456 & 0.004 & 0.155 & 0.016 & 0.000 & 0.000 & 0.417 & 0.005 & 0.153 & 0.016 & 0.526 & 0.008 & 0.010 & 0.014 & 0.010 & 0.000 \\
\hline Catatoms & 4.000 & 0.000 & 3.000 & 0.000 & 4.000 & 0.000 & 3.000 & 0.000 & 4.000 & 0.000 & 4.000 & 0.000 & 3.000 & 0.000 & 12.000 & 0.000 & 1.000 & 0.000 \\
\hline Oxygen & 6.697 & & 5.680 & & 6.897 & & 4.982 & & 6.760 & & 6.943 & & 5.723 & - & 18.818 & & 1.988 & \\
\hline $\mathrm{Ce}^{-} / \mathrm{Le}$ & 0.330 & & 0.330 & & 0.330 & & 0.000 & & 0.263 & & 0.263 & & 0.263 & & 0.000 & & 0.000 & \\
\hline $\mathrm{Ca}$ & 0.000 & & 0.000 & & 0.775 & & 0.000 & & 0.000 & & 0.744 & & 0.000 & & 0.000 & & 0.000 & \\
\hline $\mathrm{Gd}$ & 0.000 & & 0.000 & & 0.175 & & 0.000 & & 0.000 & & 0.181 & & 0.000 & & 0.000 & & 0.000 & \\
\hline $\mathrm{Ce}^{* 3}$ & 0.000 & & 0.000 & & 0.075 & & 0.000 & & 0.000 & & 0.071 & & 0.000 & & 0.000 & & 0.000 & \\
\hline $\mathrm{Ce}^{-}$ & 0.000 & & 0.000 & & 0.037 & & 0.000 & & 0.000 & & 0.025 & & 0.000 & & 0.000 & & 0.000 & \\
\hline Sum & 0.000 & & 0.000 & & 1.025 & & 0.000 & & 0.000 & & 0.995 & & 0.000 & & 0.000 & & 0.000 & \\
\hline Charge & 0.000 & & 0.000 & & 2.448 & & 0.000 & & 0.000 & & 2.343 & & 0.000 & & 0.000 & & 0.000 & \\
\hline $\mathrm{Ca}$ & 1.051 & & 0.084 & & 0.000 & & 0.001 & & 1.005 & & 0.000 & & 0.071 & & 0.423 & & 0.000 & \\
\hline $\mathrm{Al}$ & 0.000 & & 0.004 & & 0.167 & & 2.036 & & 0.000 & & 0.193 & & 0.000 & & & & 0.000 & \\
\hline$C_{e}{ }^{\prime \prime}$ & 0.177 & & 0.158 & & 0.037 & & 0.000 & & 0.164 & & 0.025 & & 0.151 & & 0.347 & & 0.000 & \\
\hline$c^{*}$ & 0.087 & & 0.078 & & 0.000 & & 0.000 & & 0.059 & & 0.000 & & 0.054 & & & & 0.000 & \\
\hline $\mathrm{Gd}$ & 0.211 & & 0.131 & & 0.000 & & 0.000 & & 0.231 & & 0.000 & & 0.131 & & 0.031 & & 0.000 & \\
\hline Hf & 0.089 & & 0.091 & & 0.616 & & 0.000 & & 0.125 & & 0.634 & & 0.066 & & 0.030 & & 0.000 & \\
\hline $\mathrm{u}$ & 0.384 & & 0.456 & & 0.155 & & 0.000 & & 0.417 & & 0.153 & & 0.526 & & 0.010 & & 0.000 & \\
\hline Sum & 2.000 & & 1.000 & & 0.975 & & 2.036 & & 2.000 & & 1.005 & & 1.000 & & 0.842 & & 0.000 & \\
\hline Charge & 6.028 & & 4.114 & & 4.628 & & 6.108 & & 6.018 & & 4.706 & & 4.075 & & 2.142 & & 0.000 & \\
\hline $\mathrm{Ti}$ & 1.912 & & 1.897 & & 1.799 & & 0.964 & & 1.961 & & 1.843 & & 1.912 & & 2.018 & & 0.920 & \\
\hline $\mathrm{Hf}$ & 0.060 & & 0.000 & & 0.000 & & 0.000 & & 0.021 & & 0.000 & & 0.014 & & 0.000 & & 0.049 & \\
\hline $\mathrm{Al}$ & 0.028 & & 0.103 & & 0.201 & & 0.014 & & 0.018 & & 0.157 & & 0.075 & & 9.141 & & 0.018 & \\
\hline Sum & 2.000 & & 2.000 & & 2.000 & & 0.978 & & 2.000 & & 2.000 & & 2.000 & & 11.158 & & 0.987 & \\
\hline Charge & 7.972 & & 7.897 & & 7.799 & & 3.897 & & 7.982 & & 7.843 & & 7.925 & & 35.493 & & 3.931 & \\
\hline vor & 2.675 & & 2.629 & & 2.186 & & 2.000 & & 2.506 & & 2.046 & & 2.475 & & 2.000 & & 3.950 & \\
\hline Total & 4.000 & & 3.000 & & 4.000 & & 3.014 & & 4.000 & & 4.000 & & 3.000 & & 12.000 & & 0.987 & \\
\hline $\begin{array}{l}\text { Model } \\
\text { Oxygens }\end{array}$ & 7.000 & & 6.000 & & 7.000 & & 5.003 & & 7.000 & & 7.000 & & 6.000 & & 18.818 & & 1.975 & \\
\hline
\end{tabular}




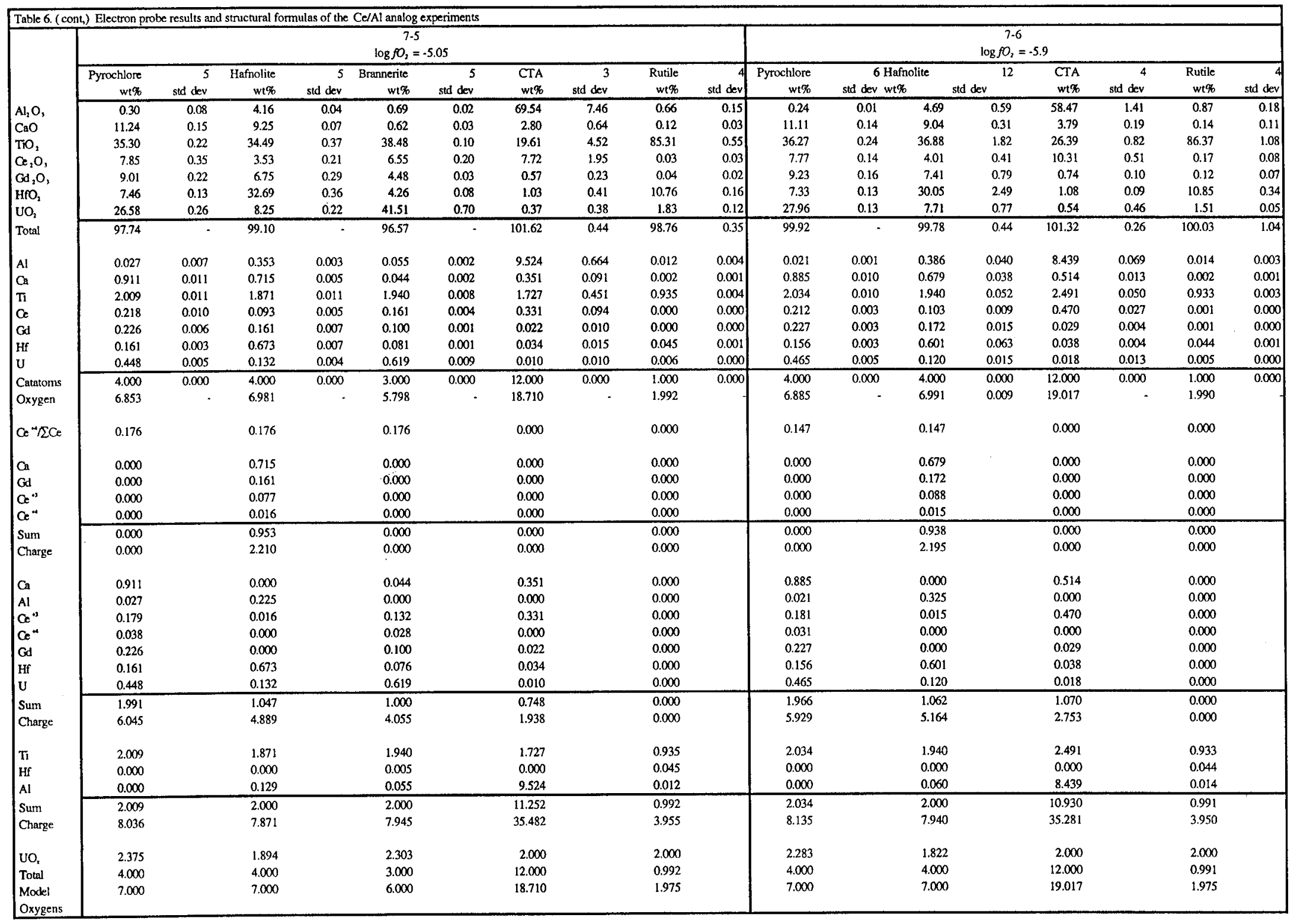




\begin{tabular}{|c|c|c|c|c|c|c|c|c|c|c|c|c|c|c|c|c|}
\hline \multirow{10}{*}{$\begin{array}{l}\mathrm{Al}_{3} \mathrm{O}, \\
\mathrm{CaO} \\
\mathrm{TOO}_{2} \\
\mathrm{Ce}_{2} \mathrm{O} \\
\mathrm{Ca}_{2} \mathrm{O}, \\
\mathrm{HfO}_{2} \\
\mathrm{UO}_{2} \\
\text { Total }\end{array}$} & \multicolumn{8}{|c|}{$\begin{array}{c}7-9 \\
\log \mathrm{fO}_{2}=-6.83 \\
\end{array}$} & \multicolumn{8}{|c|}{$\begin{array}{c}7-7 \\
\log f_{2}=-8.00\end{array}$} \\
\hline & $\begin{array}{r}\begin{array}{r}\text { Pyrochlore } \\
\text { wi\% } \%\end{array} \\
\end{array}$ & $\begin{array}{r}6 \\
\text { std der }\end{array}$ & $\begin{array}{r}\text { Hafnolite } \\
\text { w1\% }\end{array}$ & $\begin{array}{r}6 \\
\text { std dev } \\
\text { se }\end{array}$ & $\begin{array}{r}\text { Perovskite } \\
\text { wit\% }\end{array}$ & $\begin{array}{r}6 \\
\text { sted dev }\end{array}$ & $\begin{array}{l}\text { CTA } \\
w t \%\end{array}$ & std dev & $\begin{array}{r}\text { Pymochlore } \\
\text { wt\% }\end{array}$ & $\begin{array}{r}6 \\
\text { std dev }\end{array}$ & $\begin{array}{r}\text { Hafnolite } \\
\text { wt\% }\end{array}$ & $\begin{array}{r}6 \\
\text { std dev }\end{array}$ & $\begin{array}{r}\begin{array}{r}\text { Perovskite } \\
\text { wt\% }\end{array} \\
\end{array}$ & $\begin{array}{r}6 \\
\text { std dev }\end{array}$ & $\begin{array}{l}\text { CTA } \\
w \% \%\end{array}$ & std dev \\
\hline & 0.23 & 0.01 & 6.09 & 0.05 & 2.06 & 0.07 & 60.77 & 0.90 & 0.26 & 0.01 & 5.26 & 0.06 & 1.93 & 0.08 & 57.09 & 0.50 \\
\hline & 10.99 & 0.05 & 8.89 & 0.08 & 20.41 & 0.64 & 3.89 & 0.24 & 10.13 & 0.13 & 8.39 & 0.13 & 20.53 & 0.39 & 3.83 & 0.16 \\
\hline & 36.56 & 0.19 & 38.83 & 0.33 & 47.10 & 0.39 & 27.25 & 0.65 & 35.62 & 0.24 & 37.24 & 0.72 & 46.34 & 0.57 & 27.28 & 0.23 \\
\hline & 7.50 & 0.21 & 4.30 & 0.20 & 23.48 & 1.45 & 10.44 & 0.37 & 6.91 & 0.10 & 4.17 & 0.24 & 23.01 & 1.13 & 10.74 & 0.46 \\
\hline & 8.65 & 0.18 & 7.63 & 0.21 & 5.00 & 0.50 & 0.86 & 0.18 & 8.67 & 0.18 & 6.86 & 0.40 & 5.39 & 0.35 & 0.89 & 0.19 \\
\hline & 7.26 & 0.25 & 28.13 & 0.73 & 0.34 & 0.11 & 1.17 & 0.09 & 7.19 & 0.12 & 28.77 & 0.97 & 0.79 & 0.09 & 1.16 & 0.24 \\
\hline & 27.92 & 0.23 & 7.66 & 0.12 & 1.99 & 0.12 & 0.83 & 0.25 & 29.48 & 0.45 & 8.58 & 0.19 & 2.39 & 0.16 & 0.52 & 0.63 \\
\hline & 99.10 & $\cdot$ & 101.51 & - & 100.38 & 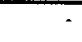 & 105.21 & & 98.26 & & 99.28 & - & 100.38 & 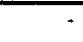 & 101.52 & 0.22 \\
\hline Al & 0.020 & 0.001 & 0.480 & 0.004 & 0.069 & 0.002 & 8.518 & 0.105 & 0.023 & 0.001 & 0.434 & 0.007 & 0.065 & 0.003 & 8.353 & 0.040 \\
\hline a & 0.881 & 0.004 & 0.638 & 0.006 & 0.620 & 0.014 & 0.495 & 0.030 & 0.839 & 0.011 & 0.629 & 0.007 & 0.628 & 0.009 & 0.519 & 0.018 \\
\hline $\mathrm{Ti}$ & 2.058 & 0.009 & 1.955 & 0.014 & 1.005 & 0.011 & 2.437 & 0.062 & 2.059 & 0.011 & 1.961 & 0.024 & 0.994 & 0.005 & 2.550 & 0.013 \\
\hline$c$ & 0.206 & 0.006 & 0.105 & 0.005 & 0.244 & 0.016 & 0.454 & 0.018 & 0.194 & 0.003 & 0.107 & 0.006 & 0.240 & 0.013 & 0.480 & 0.012 \\
\hline$G d$ & 0.214 & 0.005 & 0.169 & 0.005 & 0.047 & 0.004 & 0.034 & 0.007 & 0.221 & 0.005 & 0.159 & 0.009 & 0.051 & 0.003 & 0.039 & 0.008 \\
\hline $\mathrm{Hf}$ & 0.155 & 0.005 & 0.538 & 0.014 & 0.003 & 0.001 & 0.040 & 0.003 & 0.158 & 0.002 & 0.575 & 0.023 & 0.006 & 0.001 & 0.043 & 0.010 \\
\hline $\mathrm{u}$ & 0.465 & 0.004 & 0.114 & 0.002 & 0.013 & 0.001 & 0.022 & 0.006 & 0.506 & 0.009 & 0.134 & 0.003 & 0.015 & 0.001 & 0.016 & 0.021 \\
\hline Catatoms & 4.000 & 0.000 & 4.000 & 0.000 & 2.000 & 0.000 & 12.000 & & 4.000 & 0.000 & 4.000 & 0.000 & 2.000 & 0.000 & 12.000 & 0.000 \\
\hline Oxygen & 6.898 & & 6.984 & & 3.200 & . & 19.002 & & 6.942 & & 7.020 & - & 3.194 & - & 19.045 & \\
\hline$c^{-4} \sqrt{2} c_{e}$ & 0.114 & & 0.114 & & 0.114 & & 0.000 & & 0.073 & & 0.073 & & 0.073 & & 0.000 & \\
\hline$a$ & 0.000 & & 0.638 & & 0.000 & & 0.000 & & 0.000 & & 0.762 & & 0.000 & & 0.000 & \\
\hline$G d$ & 0.000 & & 0.169 & & 0.000 & & 0.000 & & 0.000 & & 0.127 & & 0.000 & & 0.000 & \\
\hline$C^{\prime \prime}$ & 0.000 & & 0.093 & & 0.000 & & 0.000 & & 0.000 & & 0.084 & & 0.000 & & 0.000 & \\
\hline$c^{*}$ & 0.000 & & 0.012 & & 0.000 & & 0.000 & & 0.000 & & 0.000 & & 0.000 & & 0.000 & \\
\hline Sum & 0.000 & & 0.901 & & 0.000 & & 0.000 & & 0.000 & & 0.973 & & 0.000 & & 0.000 & \\
\hline Charge & 0.000 & & 2.112 & & 0.000 & & 0.000 & & 0.000 & & 2.156 & & 0.000 & & 0.000 & \\
\hline ca & 0.881 & & 0.000 & & 0.620 & & 0.495 & & 0.839 & & 0.000 & & 0.628 & & 0.519 & \\
\hline Al & 0.020 & & 0.436 & & 0.069 & & 0.000 & & 0.023 & & 0.183 & & 0.065 & & 0.000 & \\
\hline$\alpha^{\prime \prime}$ & 0.182 & & 0.012 & & 0.244 & & 0.454 & & 0.180 & & 0.000 & & 0.223 & & 0.480 & \\
\hline $\mathrm{Ce}^{*}$ & 0.023 & & 0.000 & & 0.000 & & 0.000 & & 0.014 & & 0.000 & & 0.017 & & 0.000 & \\
\hline$G d$ & 0.214 & & 0.000 & & 0.047 & & 0.034 & & 0.221 & & 0.000 & & 0.051 & & 0.039 & \\
\hline $\mathrm{HF}$ & 0.155 & & 0.538 & & 0.000 & & 0.040 & & 0.158 & & 0.769 & & 0.006 & & 0.043 & \\
\hline $\mathrm{u}$ & 0.465 & & 0.114 & & 0.013 & & 0.022 & & 0.506 & & 0.075 & & 0.015 & & 0.016 & \\
\hline Sum & 1.942 & & 1.099 & & 0.993 & & 1.045 & & 1.941 & & 1.027 & & 1.006 & & 1.097 & \\
\hline Charge & 5.829 & & 5.567 & & 2.370 & & 2.702 & & 5.835 & & 3.926 & & 2.428 & & 2.831 & \\
\hline $\mathrm{Ti}$ & 2.058 & & 1.955 & & 1.005 & & 2.437 & & 2.059 & & 1.996 & & 0.994 & & 2.550 & \\
\hline Hf & 0.000 & & 0.000 & & 0.003 & & 0.000 & & 0.000 & & 0.000 & & 0.000 & & 0.000 & \\
\hline Al & 0.000 & & 0.045 & & 0.000 & & 8.518 & & 0.000 & & 0.004 & & 0.000 & & 8.353 & \\
\hline Sum & 2.058 & & 2.000 & & 1.007 & & 10.955 & & 2.059 & & 2.000 & & 0.994 & & 10.903 & \\
\hline Charge & 8.232 & & 7.955 & & 4.030 & & 35.301 & & 8.236 & & 7.996 & & 3.977 & & 35.259 & \\
\hline $\mathrm{UO}_{\mathrm{x}}$ & 2.259 & & 1.926 & & 2.000 & & 2.000 & & 2.170 & & 1.482 & & 2.000 & & 2.000 & \\
\hline Total & 4.000 & & 4.000 & & 2.000 & & 12.000 & & 4.000 & & 4.000 & & 2.000 & & 12.000 & \\
\hline $\begin{array}{l}\text { Model } \\
\text { Oxygens }\end{array}$ & 7.000 & & 7.000 & & 3.200 & & 19.002 & & 7.000 & & 7.000 & & 3.203 & & 19.045 & \\
\hline
\end{tabular}




\begin{tabular}{|c|c|c|c|c|c|c|c|c|}
\hline \multirow{10}{*}{$\begin{array}{l}\mathrm{Al}_{2} \mathrm{O}_{3} \\
\mathrm{CaO} \\
\mathrm{TOO}_{2} \\
\mathrm{Ce}_{2}, \mathrm{O}_{3} \\
\mathrm{Cd}_{2} \mathrm{O}_{3} \\
\mathrm{HrO}_{2} \\
\mathrm{UO}_{2} \\
\text { Total }\end{array}$} & \multicolumn{8}{|c|}{$\begin{array}{c}7.8 \\
\log \mathrm{PO}_{2}=-10.06\end{array}$} \\
\hline & $\begin{array}{r}\text { Pyrochlore } \\
\text { wt\% }\end{array}$ & 4 & $\begin{array}{r}\text { Hafnolite } \\
\text { wits }\end{array}$ & $\begin{array}{r}4 \\
\text { std der }\end{array}$ & $\begin{array}{r}\begin{array}{r}\text { Perovskite } \\
w 1 \%\end{array} \\
\end{array}$ & $\begin{array}{r}4 \\
\text { std der }\end{array}$ & $\begin{array}{l}\text { CTA } \\
w_{1 \%} \%\end{array}$ & std dev \\
\hline & 0.31 & 0.08 & 5.10 & 0.05 & 1.95 & 0.18 & 56.43 & 1.07 \\
\hline & 9.59 & 0.09 & 7.86 & 0.06 & 21.26 & 0.85 & 3.66 & 0.26 \\
\hline & 34.56 & 0.42 & 38.49 & 0.26 & 46.29 & 0.69 & 26.99 & 0.89 \\
\hline & 6.07 & 0.07 & 3.80 & 0.10 & 21.54 & 1.30 & 10.27 & 0.60 \\
\hline & 8.80 & 0.28 & 7.62 & 0.39 & 5.36 & 0.38 & 0.79 & 0.13 \\
\hline & 7.61 & 0.08 & 26.72 & 0.08 & 0.98 & 0.43 & 1.26 & 0.19 \\
\hline & 30.64 & 0.57 & 10.04 & 0.07 & 3.21 & 0.21 & 0.37 & 0.22 \\
\hline & 97.58 & 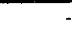 & 99.62 & - & 100.59 & . & 99.77 & 0.84 \\
\hline Al & 0.029 & 0.007 & 0.420 & 0.005 & 0.065 & 0.006 & 8.383 & 0.167 \\
\hline $\mathrm{Ca}$ & 0.810 & 0.007 & 0.589 & 0.004 & 0.646 & 0.020 & 0.493 & 0.043 \\
\hline $\mathrm{Ti}$ & 2.048 & 0.019 & 2.026 & 0.011 & 0.987 & 0.010 & 2.545 & 0.107 \\
\hline ce & 0.175 & 0.002 & 0.097 & 0.002 & 0.224 & 0.015 & 0.484 & 0.023 \\
\hline Gd & 0.230 & 0.007 & 0.177 & 0.009 & 0.050 & 0.004 & 0.034 & 0.005 \\
\hline Hf & 0.171 & 0.002 & 0.534 & 0.002 & 0.008 & 0.004 & 0.048 & 0.006 \\
\hline $\mathrm{u}$ & 0.537 & 0.011 & 0.156 & 0.001 & 0.020 & 0.001 & 0.012 & 0.006 \\
\hline Catatoms & 4.000 & 0.000 & 4.000 & 0.000 & 2.000 & 0.000 & 12.000 & 0.000 \\
\hline Oxygen & 6.973 & & 7.063 & . & 3.185 & . & 19.056 & \\
\hline$c^{*} / \Sigma C e$ & 0.000 & & 0.000 & & 0.000 & & 0.000 & \\
\hline a & 0.000 & & 0.589 & & 0.000 & & 0.000 & \\
\hline Gd & 0.000 & & 0.177 & & 0.000 & & 0.000 & \\
\hline$c^{\prime \prime}$ & 0.000 & & 0.097 & & 0.000 & & 0.000 & \\
\hline$c^{4}$ & 0.000 & & 0.000 & & 0.000 & & 0.000 & \\
\hline Sum & 0.000 & & 0.864 & & 0.000 & & 0.000 & \\
\hline Charge & 0.000 & & 2.002 & & 0.000 & & 0.000 & \\
\hline $\mathrm{Ca}$ & 0.810 & & 0.000 & & 0.646 & & 0.493 & \\
\hline Al & 0.029 & & 0.420 & & 0.065 & & 0.000 & \\
\hline$C_{e}{ }^{\prime \prime}$ & 0.175 & & 0.000 & & 0.224 & & 0.484 & \\
\hline $\mathrm{Ce}^{+}$ & 0.000 & & 0.000 & & 0.000 & & 0.000 & \\
\hline Gd & 0.230 & & 0.000 & & 0.050 & & 0.034 & \\
\hline $\mathrm{Hf}$ & 0.171 & & 0.534 & & 0.008 & & 0.048 & \\
\hline $\mathrm{u}$ & 0.537 & & 0.156 & & 0.020 & & 0.012 & \\
\hline Sum & 1.952 & & 1.110 & & 1.013 & & 1.072 & \\
\hline Charge & 5.897 & & 5.448 & & 2.422 & & 2.782 & \\
\hline$\pi$ & 2.048 & & 2.026 & & 0.987 & & 2.545 & \\
\hline Hf & 0.000 & & 0.000 & & 0.000 & & 0.000 & \\
\hline$A I$ & 0.000 & & 0.000 & & 0.000 & & 8.383 & \\
\hline Sum & 2.048 & & 2.026 & & 0.987 & & 10.928 & \\
\hline Charge & 8.191 & & 8.103 & & 3.948 & & 35.330 & \\
\hline $\mathrm{UO}_{z}$ & 2.132 & & 6.562 & & 2.000 & & 2.000 & \\
\hline Total & 4.000 & & 1.596 & & 2.000 & & 12.000 & \\
\hline Model & 7.000 & & 7.000 & & 3.185 & & 19.056 & \\
\hline Oxygens & & & & & & & & \\
\hline
\end{tabular}




\begin{tabular}{|c|c|c|c|c|c|c|c|c|}
\hline & $\mathrm{CaUTiAlO}_{7}$ & $\mathrm{CaTi}_{3} \mathrm{O}_{7}$ & $\mathrm{Ce}_{2} \mathrm{Ti}_{2} \mathrm{O}_{7}$ & $\mathrm{Gd}_{2} \mathrm{Ti}_{2} \mathrm{O}_{7}$ & $\mathrm{CaHfTi}_{2} \mathrm{O}_{7}$ & $\mathrm{CaThTi}_{2} \mathrm{O}_{7}$ & $\mathrm{Ca}_{1.5} \mathrm{U}_{0.5} \mathrm{Ti}_{2} \mathrm{O}_{7}$ & $\mathrm{CaUTi}_{2} \mathrm{O}_{7}$ \\
\hline \multicolumn{9}{|c|}{ Ce Analog } \\
\hline $1 / 3$ & 0.015 & -0.061 & 0.123 & 0.116 & 0.221 & 0.000 & 0.501 & 0.086 \\
\hline $1 / 4$ & 0.024 & -0.065 & 0.122 & 0.119 & 0.221 & 0.000 & 0.417 & 0.163 \\
\hline $1 / 5$ & 0.011 & 0.027 & 0.119 & 0.113 & 0.216 & 0.000 & 0.238 & 0.277 \\
\hline $1 / 6$ & 0.011 & 0.046 & 0.117 & 0.111 & 0.215 & 0.000 & 0.212 & 0.289 \\
\hline $1 / 9$ & 0.011 & 0.058 & 0.112 & 0.112 & 0.224 & 0.000 & 0.148 & 0.336 \\
\hline $1 / 7$ & 0.009 & 0.065 & 0.105 & 0.116 & 0.232 & 0.000 & 0.103 & 0.371 \\
\hline $1 / 8$ & 0.009 & 0.088 & 0.098 & 0.118 & 0.224 & 0.000 & 0.034 & 0.430 \\
\hline \multicolumn{9}{|c|}{ Ce/Al Analog } \\
\hline $7 / 3$ & 0.028 & -0.060 & 0.133 & 0.106 & 0.148 & 0.000 & 0.579 & 0.067 \\
\hline $7 / 4$ & 0.018 & -0.021 & 0.112 & 0.116 & 0.146 & 0.000 & 0.464 & 0.167 \\
\hline $7 / 5$ & 0.027 & 0.036 & 0.109 & 0.113 & 0.161 & 0.000 & 0.266 & 0.288 \\
\hline $7 / 6$ & 0.021 & 0.055 & 0.106 & 0.114 & 0.156 & 0.000 & 0.209 & 0.340 \\
\hline $7 / 9$ & 0.020 & 0.078 & 0.103 & 0.107 & 0.155 & 0.000 & 0.183 & 0.353 \\
\hline $7 / 7$ & 0.023 & 0.082 & 0.097 & 0.111 & 0.158 & 0.000 & 0.093 & 0.437 \\
\hline $7 / 8$ & 0.029 & 0.077 & 0.088 & 0.115 & 0.171 & 0.000 & 0.025 & 0.496 \\
\hline \multicolumn{9}{|c|}{ Th Analog } \\
\hline $8 / 3$ & 0.000 & -0.091 & 0.000 & 0.109 & 0.232 & 0.143 & 0.454 & 0.154 \\
\hline $8 / 4$ & 0.004 & $-0.05 d$ & 0.000 & 0.110 & 0.240 & 0.149 & 0.405 & 0.143 \\
\hline $8 / 5$ & 0.010 & 0.023 & 0.000 & 0.110 & 0.229 & 0.162 & 0.276 & 0.190 \\
\hline $8 / 6$ & 0.006 & 0.025 & 0.000 & 0.113 & 0.226 & 0.166 & 0.223 & 0.242 \\
\hline $8 / 9$ & 0.008 & 0.040 & 0.000 & 0.107 & 0.239 & 0.179 & 0.166 & 0.262 \\
\hline $8 / 7$ & 0.010 & 0.040 & 0.000 & 0.109 & 0.236 & 0.189 & 0.124 & 0.293 \\
\hline $8 / 8$ & 0.009 & 0.060 & 0.000 & 0.107 & 0.236 & 0.198 & 0.041 & 0.350 \\
\hline
\end{tabular}




\section{Discussion}

\subsection{Oxidation states}

As is the case with plutonium, cerium and uranium can both be present in more than a single valence state, and the distribution of each of these elements among the possible valence states will depend upon temperature, $\mathrm{fO}_{2}$ and mineral chemistry. Due to the polyphase nature of the samples investigated here, the valence of these cations has not been directly determined by either spectroscopic or wet chemical methods. Instead, we present a simple model based upon the ideal stoichiometry of the phases in question coupled with spectroscopic determinations from other workers to constrain the range of possible valence state distributions. The major caveat is that these constraints depend upon the assumption of ideal stoichiometry; if any of the phases in question has significant concentrations of defects, then these constraints must be reevaluated and modified.

Pyrochlore and brannerite are oxygen deficient for stoichiometries based on $\mathrm{Ce}^{+3}$ and $\mathrm{U}^{+4}$ for each of the starting compositions (Table 4, 5, 6). For example, if uranium and cerium are assumed to be present as +4 and +3 cations, respectively, then the pyrochlore and brannerite from the $\mathrm{Ce}-\mathrm{Al}$ analog run in air yield 6.7 and 5.7 oxygens for 4 and 3

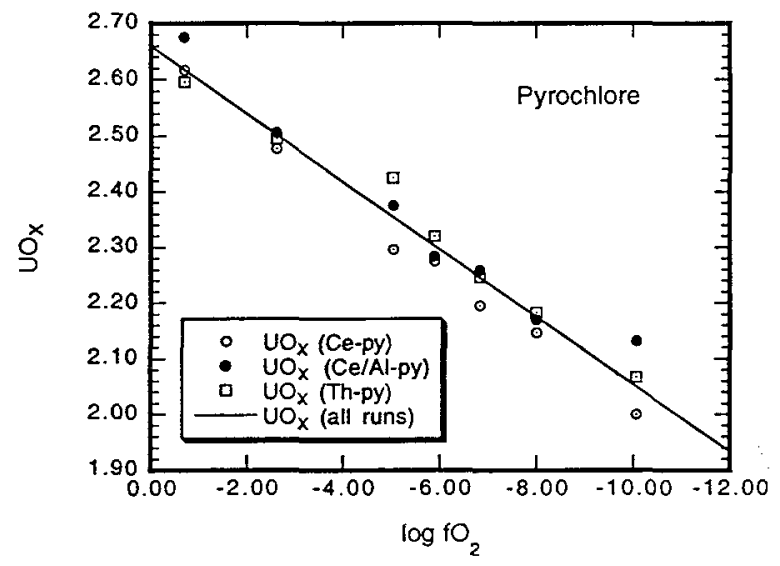

Figure 18. Average uranium oxidation state for pyrochlore as a function of $\log \mathrm{fO}_{2}$. The calculation assumes that $\mathrm{Ce}^{+4} / \Sigma \mathrm{Ce}=0.33$ in air, and 0 at $\log \mathrm{fO}_{2}=-10 . \mathrm{UO}_{\mathrm{x}}$ is then adjusted to produce ideal pyrochlore stoichiometry (see text). cations, respectively (Table 6). Conversely, hafnolite approaches ideality in air, and perovskite is actually cation deficient. To achieve ideal pyrochlore and brannerite stoichiometry, either $\mathrm{U}$ or $\mathrm{Ce}$, or some combination of these elements must exist in a higher valence state. Similarly in the Th-analog, where $U$ is the only cation with multiple valence states, a run in air yields 6.8 and 5.8 oxygens for 4 and 3 cations for pyrochlore and brannerite, respectively (Table 5). If ideal stoichiometry is achieved in these phases, then the Thanalog runs require that at least some fraction of the uranium must be present in a valence state higher than +4 . Comparison of the $\mathrm{Ce}-\mathrm{Al}$ and $\mathrm{Th}$-analog runs also indicates that the Th-analog runs produce samples slightly closer to ideal stoichiometry than the Ce$\mathrm{Al}$ and $\mathrm{Ce}-$ runs. The simplest explanation is that $\mathrm{Ce}$ must also be present as both $\mathrm{Ce}^{+3}$ and 
$\mathrm{Ce}^{+4}$. Mixed valences for $\mathrm{Ce}$ and $\mathrm{U}$ are supported by the work of Fortner et al. (1999), who determined the valence of $\mathrm{Ce}$ and $\mathrm{U}$ in a ceramic formulation similar to those presented here using XANES and EXAFS spectroscopy. They found that cerium exists in a mixed oxidation state $\left(\mathrm{Ce}^{+4} / \mathrm{Se} \sim 0.33\right)$ and that uranium is present largely as the pentavalent species (personal communication, 1999). Xu and Wang (1999) have also identified $\mathrm{Ce}^{+4}$ in natural pyrochlores by electron energy loss spectroscopy (EELS).

At the lowest $\mathrm{fO}_{2} \mathrm{~s}\left(\log \mathrm{fO}_{2}=-10\right.$, runs $1 / 8,7 / 8$ and $8 / 8$, Table $\left.4,5,6\right)$ pyrochlore and brannerite are, within analytical error, stoichiometric based on $\mathrm{Ce}^{+3}$ and $\mathrm{U}^{+4}$ for each of the starting compositions. Hence, at $\mathrm{fO}_{2} \mathrm{~s}$ between air and $\log \mathrm{fO}_{2}=-10$, both uranium and cerium appear to be reduced from a mixed valence state to their lowest valence. To model the variation in valence state as a function of oxygen fugacity, we assume, following Fortner et al. (1999) that the $\mathrm{Ce}^{+4} / \Sigma \mathrm{Ce}$ for both pyrochlore and brannerite is 0.33 in air, and, consistent with our results, 0 at $\log \mathrm{fO}_{2}=-10$. Between these extremes, we assume that $\mathrm{Ce}^{+4} / \Sigma \mathrm{Ce}$ varies linearly with $\log \mathrm{fO}_{2}$ (see Table 4, 5, 6). By fixing the relationship between $\mathrm{Ce}^{+4} / \Sigma \mathrm{Ce}$ and $\mathrm{fO}_{2}$, we can calculate the "average oxidation state" for uranium, $\mathrm{UO}_{\mathrm{x}}$ (where $\mathrm{x}$ is the number of $\mathrm{O}^{\times}$ oxygens/uranium atom) based on the ideal $4 / 7$ and $3 / 6$ stoichiometries of pyrochlore and brannerite, respectively (see Tables 4,5 , 6). The "average valence" is obviously twice the average oxidation state, however, as various combinations of uranium valence states can satisfy the ideal stoichiometry, the result obtained is not unique, nor does it resolve the distribution of uranium among $\mathrm{U}^{+4}, \mathrm{U}^{+5}$ and $\mathrm{U}^{+6}$.

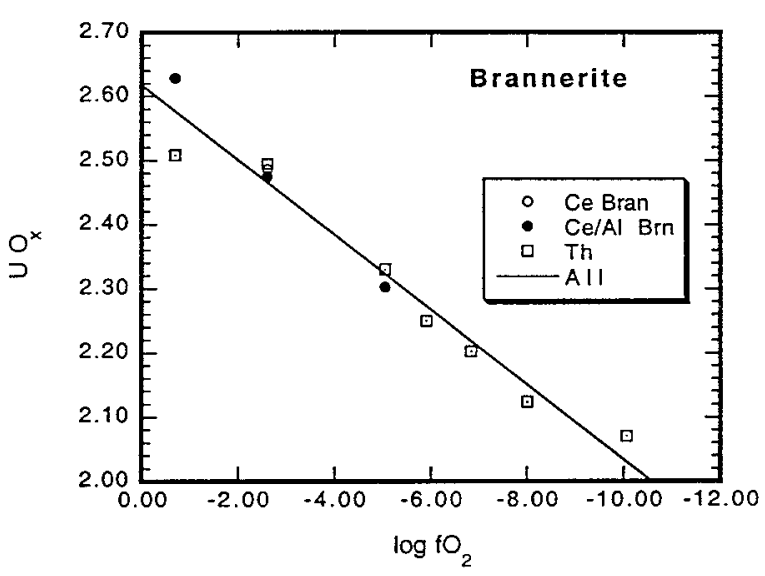

Figure 19. Average uranium oxidation state for brannerite as a function of $\log f O_{2}$. The calculation assumes that $\mathrm{Ce}^{+4} / \Sigma \mathrm{Ce}=0.33$ in air, and 0 at $\log \mathrm{fO}_{2}=-10 . \mathrm{UO}_{\mathrm{x}}$ is then adjusted to produce ideal brannerite stoichiometry (see text).

The model uranium oxidation state for pyrochlores and brannerites from each of the starting compositions decreases linearly with $\log \mathrm{fO}_{2}$ (Figure 18 and 19). The model average oxidation state in air for both phases is 2.6-2.7, equivalent to an average valence of 5.2-5.4. This result is roughly consistent with the spectroscopic observations of Fortner $e t$ al. (1999) which indicated that the uranium in pyrochlore was largely pentavalent. That $\mathrm{UO}_{x}$ is greater than 2.5 indicates that some hexavalent uranium is present; for $\mathrm{U}^{+4}=0, \mathrm{UO}_{2.6}$ is equivalent to $\mathrm{U}^{+6} / \mathrm{U}^{+5}=0.24$. 


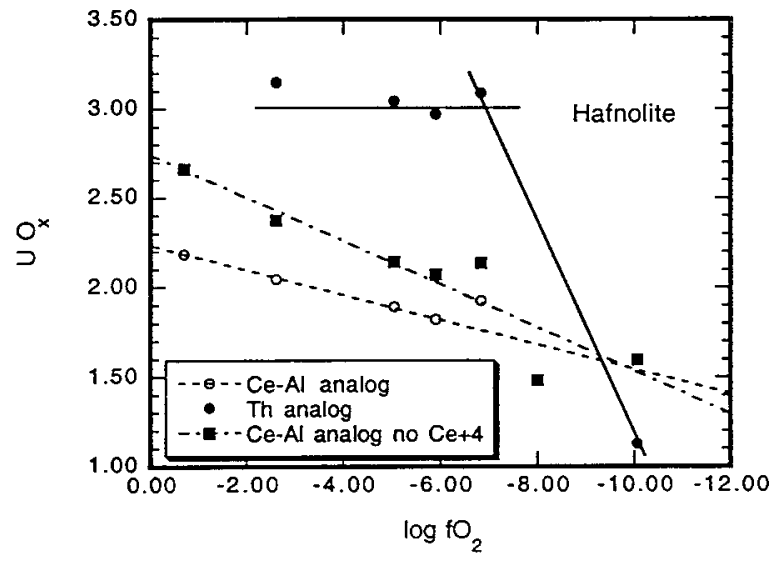

Figure 20. Average uranium oxidation state for hafnolite as a function of $\log \mathrm{fO}_{2}$. The calculation assumes that $\mathrm{Ce}^{+4} / \Sigma \mathrm{Ce}=0 . \quad \mathrm{UO}_{\mathrm{x}}$ is then adjusted to produce ideal hafnolite stoichiometry (see text).
The hafnolites from the $\mathrm{Ce}-\mathrm{Al}$ analog are very close to the ideal with the number of oxygens per 4 cations typically greater than 6.9 over the entire range of oxygen fugacities, and greater than 7.0 for the lowest $\mathrm{fO}_{2} \mathrm{~s}$ (Table 6). If we apply the model described above to these hafnolites, however, we find that the apparent average oxidation state also decreases as a linear function of $\log \mathrm{fO}_{2}$ (Figure 20). Unlike the pyrochlores, $\mathrm{UO}_{\mathrm{x}}$ for hafnolite drops below 2 which is, of course, not possible, and indicates that either the oxidation state of cerium must be higher than that prescribed by the model, or that

zirconolite is slightly cation deficient. For samples equilibrated at higher $\mathrm{fO}_{2} \mathrm{~s}$, the apparent non-stoichiometry can be rectified by reducing all the cerium to $\mathrm{Ce}^{+3}$. However, at lower $\mathrm{fO}_{2} \mathrm{~s}, \mathrm{UO}_{\mathrm{x}}$ required for stoichiometry again falls below the accessible lower bound, $\mathrm{UO}_{2}$, indicating that hafnolite must be cation deficient at least at the lowest $\mathrm{fO}_{2} \mathrm{~s}$, and potentially at higher values. The only other mechanism by which ideal hafnolite stoichiometry can be maintained is by the reduction of $\mathrm{Ti}^{+4}$ to $\mathrm{Ti}^{+3}$. In this connection, Begg et al. (1998) identified $\mathrm{Ti}^{+3}$ in zirconolites synthesized under reducing conditions, and associated the reduction of $\mathrm{Ti}$ to the appearance of perovskite in the assemblage. Samples synthesized at the lowest $\mathrm{fO}_{2} \mathrm{~s}$ in this study do indeed contain perovskite (e.g., samples 7/7, 7/8, 7/9, Table 6). For example, when all the cerium and uranium are cast as +3 and +4 , respectively, ideal stoichiometry for sample $7 / 8$ is attained with $\mathrm{Ti}^{+3} / \sum \mathrm{Ti}=0.06$. Given the large number of possible charge-balance mechanisms available, it is clear that direct observational methods are required to fully understand the structural chemistry of these phases.

\subsection{Structural components in pyrochlore, brannerite, hafnolite and perovskite}

\subsubsection{Pyrochlore}

Based upon the variations in the stoichiometry and partitioning with changing $\mathrm{fO}_{2}$ we have inferred progressive changes in the valence and site occupancy of the various 
elements investigated. Implicit in this inference is the assumption of a number of endmember components that describe the compositions of the phases in question. In this section we briefly discuss these implicit assignments and the variation in the concentrations of the components chosen with $\mathrm{fO}_{2}$.

The components chosen to model the composition of pyrochlore should attempt to describe: (1) the increase in $\mathrm{U}$ and decrease in $\mathrm{Ca}$ and $\mathrm{Ce}$ concentrations with decreasing $\mathrm{fO}_{2}$, (2) the observation that the concentrations of $\mathrm{Ca}$ and $\mathrm{Ti}$ are always close to 1 and 2 atoms normalized to 4 total cations, respectively, and (3) the inferred reduction of uranium with decreasing $\mathrm{fO}_{2}$. We have used the following components: $\mathrm{CaUTiAlO}_{7}, \mathrm{CaTi}_{3} \mathrm{O}_{7}$, $\mathrm{Ce}_{2} \mathrm{Ti}_{2} \mathrm{O}_{7}, \mathrm{Gd}_{2} \mathrm{Ti}_{2} \mathrm{O}_{7}, \mathrm{CaHfTi}_{2} \mathrm{O}_{7}, \mathrm{CaThTi}_{2} \mathrm{O}_{7}, \mathrm{CaUTi}_{2} \mathrm{O}_{7}$, and $\mathrm{Ca}_{1.5} \mathrm{U}_{0.5} \mathrm{Ti}_{2} \mathrm{O}_{7}$ (Table 7).

Uranium is included in three components, $\mathrm{CaUTi}_{2} \mathrm{O}_{7}, \mathrm{CaUTiAlO}_{7}$ and $\mathrm{Ca}_{1.5} \mathrm{U}_{0.5} \mathrm{Ti}_{2} \mathrm{O}_{7}$ which are neutral species based on the $+4,+5$ and +6 valence states of uranium and allow the apparent variations in the average oxidation state of uranium inferred above to be accommodated. $\mathrm{Gd}_{2} \mathrm{Ti}_{2} \mathrm{O}_{7}$ and $\mathrm{Ce}_{2} \mathrm{Ti}_{2} \mathrm{O}_{7}$ describe the simple trivalent lanthanide pyrochlores, while $\mathrm{CaHfTi}_{2} \mathrm{O}_{7}, \mathrm{CaThTi}_{2} \mathrm{O}_{7}, \mathrm{CaUTi}_{2} \mathrm{O}_{7}$ and $\mathrm{CaTi}_{3} \mathrm{O}_{7}$ describe components in which a divalent cation on one of the $\mathrm{A}$-sites is charge-compensated by an equal number of quadravalent cations on the $\mathrm{A}$-site. $\mathrm{CaUTi}_{2} \mathrm{O}_{7}$ assumes that uranium is present as $\mathrm{U}^{+4}$, and $\mathrm{CaTi}_{3} \mathrm{O}_{7}$ allows the number of Ti per 4 cations to exceed 2 . Cerium is accommodated only as a trivalent cation in conflict with compositional trends described above and also with direct spectroscopic determinations of cerium valence. Alternative choices of components present other difficulties. For instance, $\mathrm{Ce}^{+4}$ could be accommodated in aluminum-bearing components such as $\mathrm{CeAl}(\mathrm{AlTi}) \mathrm{O}_{7}$ in which charge excess on the A-site is balanced by a deficit on the T-site. However, this restricts the concentration of $\mathrm{Ce}^{+4}$ to be no more than half the amount of $\mathrm{Al}$, and $\mathrm{Al}$ is a minor component in pyrochlore. Inversions including this component show that its concentration increases with decreasing $\mathrm{fO}_{2}$ which is counterintuitive. $\mathrm{CaCeTi}_{2} \mathrm{O}_{7}$ is a less restrictive choice, but is related to other components through the reaction,

$$
\mathrm{CaCeTi}_{2} \mathrm{O}_{7}+1 / 2 \mathrm{CaUTi}_{2} \mathrm{O}_{7}=\mathrm{Ca}_{1.5} \mathrm{U}_{0.5} \mathrm{Ti}_{2} \mathrm{O}_{7}+1 / 2 \mathrm{Ce}_{2} \mathrm{Ti}_{2} \mathrm{O}_{7}
$$

and yields a singular matrix of inversion. 
Through trial and error, we've determined a set of components above yields the fewest number of negative concentrations (Table 7). The major components in the $\mathrm{Ce}$ - and $\mathrm{Ce} / \mathrm{Al}$ analog materials are $\mathrm{Ce}_{2} \mathrm{Ti}_{2} \mathrm{O}_{7}, \mathrm{Gd}_{2} \mathrm{Ti}_{2} \mathrm{O}_{7}, \mathrm{CaHfTi}_{2} \mathrm{O}_{7}, \mathrm{CaUTi}_{2} \mathrm{O}_{7}$, and $\mathrm{Ca}_{1.5} \mathrm{U}_{0.5} \mathrm{Ti}_{2} \mathrm{O}_{7}$. The concentration of $\mathrm{Gd}_{2} \mathrm{Ti}_{2} \mathrm{O}_{7}$ and $\mathrm{CaHfTi}_{2} \mathrm{O}_{7}$ remain constant with $\mathrm{fO}_{2}$, while $\mathrm{Ce}_{2} \mathrm{Ti}_{2} \mathrm{O}_{7}$ shows a slight decrease, consistent with the data shown in Figures 3 and 15. $\mathrm{As}_{2} \mathrm{f}_{2}$ decreases the

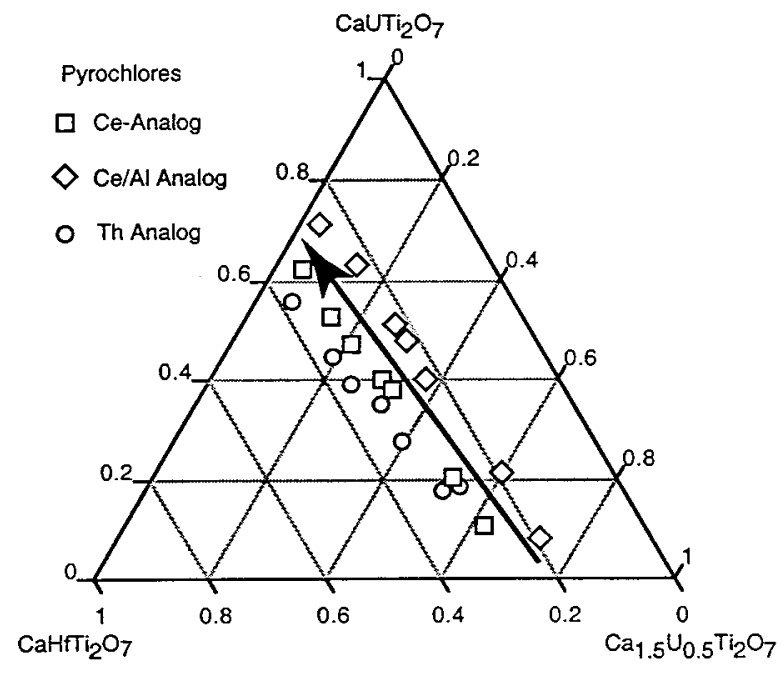

Figure 21. Pyrochlore compositions (mole fractions) in the $\mathrm{CaUTi}_{2} \mathrm{O}_{7}-\mathrm{Ca}_{1.5} \mathrm{U}_{0.5} \mathrm{Ti}_{2} \mathrm{O}_{7}$ $-\mathrm{CaHfTi}_{2} \mathrm{O}_{7}$ ternary. concentration of the quadravalent uranium component, $\mathrm{CaUTi}_{2} \mathrm{O}_{7}$, increases and that of the hexavalent uranium species, $\mathrm{Ca}_{1.5} \mathrm{U}_{0.5} \mathrm{Ti}_{2} \mathrm{O}_{7}$, decreases (Figure 21). As $\mathrm{Ca}_{1.5} \mathrm{U}_{0.5} \mathrm{Ti}_{2} \mathrm{O}_{7}$ contains more calcium per formula unit than $\mathrm{CaUTi}_{2} \mathrm{O}_{7}$ this exchange describes the decrease in $\mathrm{Ca}$ with $\mathrm{fO}_{2}$ described in Figures 3 and 15. Similarly, $\mathrm{CaUTiAlO}_{7}$ decreases with $\mathrm{fO}_{2}$ and $\mathrm{CaTi}_{3} \mathrm{O}_{7}$ increases, consistent with the observed increase in Ti normalized to 4 cations with decreasing $\mathrm{fO}_{2}$. The compositions of the pyrochlores from each bulk composition are clearly separated on $\mathrm{CaUTi}_{2} \mathrm{O}_{7}-\mathrm{Ca}_{1.5} \mathrm{U}_{0.5} \mathrm{Ti}_{2} \mathrm{O}_{7}-\mathrm{CaHfTi}_{2} \mathrm{O}_{7}$ ternary (Figure 21). The concentration of $\mathrm{CaHfTi}_{2} \mathrm{O}_{7}$ is roughly constant for each bulk composition, and the major compositional variation is the exchange of $\mathrm{Ca}_{1.5} \mathrm{U}_{0.5} \mathrm{Ti}_{2} \mathrm{O}_{7}$ for $\mathrm{CaUTi}_{2} \mathrm{O}_{7}$ as the run conditions become more reducing. At the lowest $\mathrm{fO}_{2} \mathrm{~s}$ the compositions lie essentially along the $\mathrm{CaHfTi}_{2} \mathrm{O}_{7^{-}}$ $\mathrm{CaUTi}_{2} \mathrm{O}_{7}$ join. Qualitatively similar trends are displayed by the Th-bearing materials in which $\mathrm{CaThTi}_{2} \mathrm{O}_{7}$ replaces $\mathrm{Ce}_{2} \mathrm{Ti}_{2} \mathrm{O}_{7}$.

All the pyrochlores have normalized $\mathrm{Ca}$ and $\mathrm{Ti}$ concentrations close to 1 and 2 , respectively. This is simply a consequence of the fact that the predominant phase in a highvariance phase assemblage reflects the bulk composition of the material, which in this study has a $\mathrm{Ca} / \mathrm{Ti}$ atom ratio close to 0.5 . Unlike zirconolite, there is no structural constraint limiting the amount of $\mathrm{Ca}$ on the pyrochlore A-site to $1 \mathrm{Ca}$ normalized to 4 cations. Indeed, Ryerson et al. (2000) report pyrochlores coexisting with Ca-perovskites with up to $1.2 \mathrm{Ca}$ normalized to 4 cations. 


\subsubsection{Brannerite}

Brannerite is particularly stable in the Th-analog, occurring over the entire $\mathrm{fO}_{2}$ range, and the trends in brannerite composition are best illustrated by this composition. An appropriate set of components to describe the compositions of brannerite should help to reconcile the increase in $\mathrm{U}$ with $\mathrm{fO}_{2}$ and the correlated decrease in $\mathrm{Ca}$. We propose the following components: $\mathrm{Ca}_{0.5} \mathrm{U}_{0.5} \mathrm{Ti}_{2} \mathrm{O}_{6}, \mathrm{Ce}_{0.5} \mathrm{U}_{0.5} \mathrm{Ti}_{2} \mathrm{O}_{6}, \mathrm{Gd}_{0.5} \mathrm{U}_{0.5} \mathrm{Ti}_{2} \mathrm{O}_{6}$, ThTi $\mathrm{O}_{6}, \mathrm{HfTi}_{2} \mathrm{O}_{6}$, $\mathrm{UHf}_{2} \mathrm{O}_{6}, \mathrm{UTi}_{2} \mathrm{O}_{6}$ and $\mathrm{UAlTiO}_{6}$ (Table 8). As uranium is the predominant species, it is included in all but 2 of the components. $\mathrm{UHf}_{2} \mathrm{O}_{6}$ and $\mathrm{UTi}_{2} \mathrm{O}_{6}$ contain quadravalent uranium, and $\mathrm{Ce}_{0.5} \mathrm{U}_{0.5} \mathrm{Ti}_{2} \mathrm{O}_{6}, \mathrm{Gd}_{0.5} \mathrm{U}_{0.5} \mathrm{Ti}_{2} \mathrm{O}_{6}$, and $\mathrm{UAITiO}_{6}$ contain pentavalent uranium. Hexavalent uranium is contained only in $\mathrm{Ca}_{0.5} \mathrm{U}_{0.5} \mathrm{Ti}_{2} \mathrm{O}_{6}$.

The major compositional variation is expressed in terms of $\mathrm{Ca}_{0.5} \mathrm{U}_{0.5} \mathrm{Ti}_{2} \mathrm{O}_{6}$, $\mathrm{Gd}_{0.5} \mathrm{U}_{0.5} \mathrm{Ti}_{2} \mathrm{O}_{6}$ and $\mathrm{UTi}_{2} \mathrm{O}_{6}$ (Figure 22); $\mathrm{UAlTiO}_{6}$ and $\mathrm{UHf}_{2} \mathrm{O}_{6}$ are negligible and $\mathrm{ThTi}_{2} \mathrm{O}_{6}$

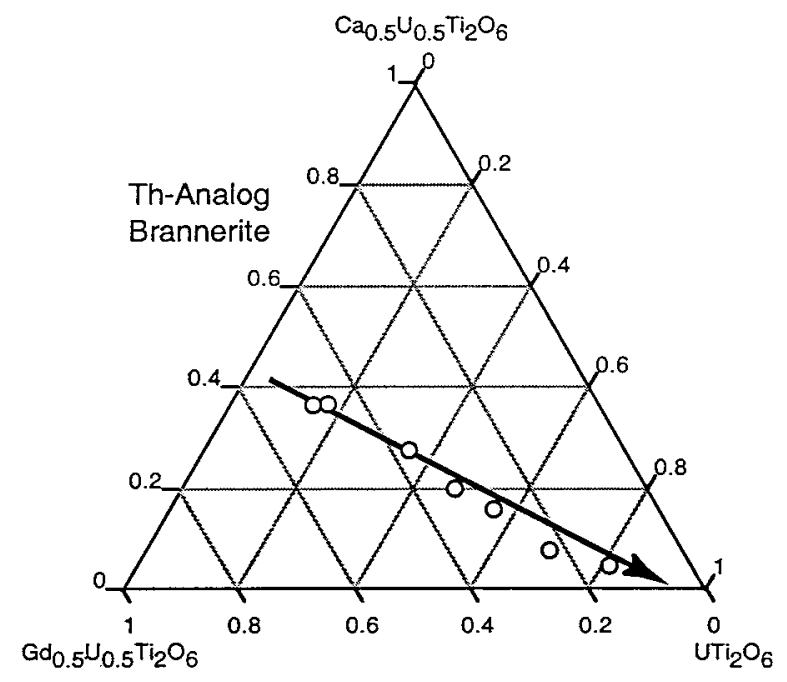

Figure 22. Brannerite compositions (mole fractions) in the $\mathrm{Ca}_{0.5} \mathrm{U}_{0.5} \mathrm{Ti}_{2} \mathrm{O}_{6}-\mathrm{Gd}_{0.5} \mathrm{U}_{0.5} \mathrm{Ti}_{2} \mathrm{O}_{6}$ $\mathrm{UTi}_{2} \mathrm{O}_{6}$ ternary. and $\mathrm{HfTi}_{2} \mathrm{O}_{6}$ are virtually constant. $\mathrm{As}_{\mathrm{fO}_{2}}$ decreases, the concentrations of the hexavalent and pentavalent uranium-bearing species decrease and that of the quadravalent, $\mathrm{UTi}_{2} \mathrm{O}_{6}$ increases. As $\mathrm{Ca}_{0.5} \mathrm{U}_{0.5} \mathrm{Ti}_{2} \mathrm{O}_{6}$ is the only Ca-bearing component, its consumption during reduction is consistent with the decreasing Ca normalized to 3 total cations illustrated in Figure 11. Conversely, the increase in the concentration of components with 0.5 uranium per formula unit for $\mathrm{UTi}_{2} \mathrm{O}_{6}$ with 1 uranium per formula unit explains the increase in $U$ normalized to 3 total cations with decreasing $\mathrm{fO}_{2}$. The trends for the $\mathrm{Ce}-\mathrm{Al}$ analog are not as well developed as those for the Th-analog, but are qualitatively consistent.

\subsubsection{Hafnolite}

Hafnolite, with the structural formula $\mathrm{ABT}_{2} \mathrm{O}_{7}$, is structurally analogous to zirconolite $\left(\mathrm{CaZrTi}_{2} \mathrm{O}_{7}\right)$ in which a large radius cation such as a lanthanide is able to occupy the A-site, and is charge compensated by a smaller tri- or divalent cation on the B-site and/or T-site. In this study hafnolite is clearly stabilized by aluminum and is present over the full range of $\mathrm{fO}_{2} \mathrm{~s}$ for the $\mathrm{Ce}-\mathrm{Al}$ analog. It is also present in some of the Th-analog materials and in 


\begin{tabular}{|c|c|c|c|c|c|c|c|c|}
\hline & $\mathrm{Ca}_{0.5} \mathrm{U}_{0.5} \mathrm{Ti}_{2} \mathrm{O}_{6}$ & $\mathrm{Ce}_{0.5} \mathrm{U}_{0.5} \mathrm{Ti}_{2} \mathrm{O}_{6}$ & $\mathrm{Gd}_{0.5} \mathrm{U}_{0.5} \mathrm{Ti}_{2} \mathrm{O}_{6}$ & $\mathrm{ThTi}_{2} \mathrm{O}_{6}$ & $\mathrm{HfTi}_{2} \mathrm{O}_{6}$ & $\mathrm{UHf}_{2} \mathrm{O}_{6}$ & $\mathrm{UTi}_{2} \mathrm{O}_{6}$ & UAlTiO $_{6}$ \\
\hline \multicolumn{9}{|c|}{ Ce Analog } \\
\hline $1 / 4$ & 0.162 & 0.415 & 0.271 & 0.000 & 0.078 & 0.018 & 0.022 & 0.033 \\
\hline \multicolumn{9}{|c|}{ Ce/Al Analog } \\
\hline $7 / 3$ & 0.167 & 0.472 & 0.261 & 0.000 & 0.094 & -0.002 & -0.099 & 0.107 \\
\hline $7 / 4$ & 0.142 & 0.411 & 0.262 & 0.000 & 0.066 & 0.007 & 0.037 & 0.075 \\
\hline $7 / 5$ & 0.089 & 0.321 & 0.199 & 0.000 & 0.076 & 0.003 & 0.257 & 0.055 \\
\hline \multicolumn{9}{|c|}{ Th Analog } \\
\hline $8 / 3$ & 0.194 & 0.000 & 0.258 & 0.334 & 0.120 & 0.012 & 0.079 & 0.003 \\
\hline $8 / 4$ & 0.196 & 0.000 & 0.247 & 0.333 & 0.106 & 0.010 & 0.092 & 0.016 \\
\hline $8 / 5$ & 0.149 & 0.000 & 0.202 & 0.335 & 0.079 & 0.020 & 0.194 & 0.021 \\
\hline $8 / 6$ & 0.104 & 0.000 & 0.169 & 0.358 & 0.102 & 0.008 & 0.245 & 0.014 \\
\hline $8 / 9$ & 0.082 & 0.000 & 0.145 & 0.351 & 0.116 & 0.006 & 0.284 & 0.016 \\
\hline 87 & 0.039 & 0.000 & 0.113 & 0.371 & 0.112 & 0.007 & 0.344 & 0.014 \\
\hline $8 / 8$ & 0.024 & 0.000 & 0.069 & 0.383 & 0.104 & 0.010 & 0.402 & 0.008 \\
\hline
\end{tabular}


some of the lower $\mathrm{fO}_{2}$ runs in the Ce-analog. As it doesn't concentrate Th, it is likely that its presence in the Ce- and Th-analog may be related to aluminum impurities from the starting materials or grinding medium.

The discussion here is focussed on the results of the Ce-Al analog runs. At high $\mathrm{fO}_{2} \mathrm{~s}$ hafnolite, based on $\mathrm{Ce}^{+3}$ and $\mathrm{U}^{+4}$, is slightly oxygen deficient, indicating the possibility of higher oxidation states. Using the same basis, hafnolite is slightly cation deficient at low $\mathrm{fO}_{2} \mathrm{~s}$, suggestive of $\mathrm{Ti}^{+3}$. The $\mathrm{T}$-site contains less than $2 \mathrm{Ti}$ cations requiring some $\mathrm{Al}$ to fill the site completely. There is, however, there is more $\mathrm{Al}$ in hafnolite than is required to fill the $\mathrm{T}$-site, indicating that $\mathrm{Al}$ is also present on the $\mathrm{B}$-site. A set of components capturing these variations is: $\mathrm{CaHfTi}_{2} \mathrm{O}_{7}, \mathrm{CaThTi}_{2} \mathrm{O}_{7}, \mathrm{CaUTi}_{2} \mathrm{O}_{7}, \mathrm{CaCeTi}_{2} \mathrm{O}_{7}, \mathrm{GdUTi}_{2} \mathrm{O}_{7}, \mathrm{GdAlTi}_{2} \mathrm{O}_{7}$, $\mathrm{CeAlTi}_{2} \mathrm{O}_{7}, \mathrm{Gd}\left(\mathrm{U}_{0.5} \mathrm{~A}_{1.5}\right) \mathrm{AlTiO}_{7}$ (Table 9). The nominal $\mathrm{A}^{+2} \mathrm{~B}^{+4} \mathrm{~T}^{+4}{ }_{2} \mathrm{O}_{7}$ stoichiometry is expressed by the components $\mathrm{CaCe}^{+4} \mathrm{Ti}_{2} \mathrm{O}_{7}, \mathrm{CaHfTi}_{2} \mathrm{O}_{7}, \mathrm{CaThTi}_{2} \mathrm{O}_{7}$ and $\mathrm{CaUTi}_{2} \mathrm{O}_{7}$. A more complex coupled substitution involving pentavalent uranium is required to form $\mathrm{Gd}\left(\mathrm{U}_{0.5} \mathrm{Al}_{0.5}\right)(\mathrm{AlTi}) \mathrm{O}_{7}$. Here, aluminum resides on both the $\mathrm{B}$ - and T-sites. $\mathrm{Al}$ on the Tsite balances the charge excess produced by placing $\mathrm{Gd}$ on the A-site; a coupled substitution of pentavalent uranium and aluminum maintains charge balance on the B-site. Coupled substitution on only the $\mathrm{A}$ - and $\mathrm{B}$-sites is required to form the components $\mathrm{GdAlTi}_{2} \mathrm{O}_{7}$ and $\mathrm{Ce}^{+3} \mathrm{AlTi}_{2} \mathrm{O}_{7}$ in which the charge excess on the A-site is balanced by $\mathrm{Al}$ on the B-site. Finally a reduced component that includes both $\mathrm{U}^{+4}$ and $\mathrm{Ti}^{+3}$ is expressed by $\mathrm{GdUTi}_{2} \mathrm{O}_{7}$; the charge excess on the A-site is balanced by placing $\mathrm{Ti}^{+3}$ on the $\mathrm{T}$-site.

When applied to the hafnolites analyzed in the Ce-, Ce/Al- and Th- analog materials, the set of components described above generates a relatively large number of negative concentrations (Table 9a). The absolute value of these negative concentrations is generally less than 0.10 , and they are largely observed for the reduced species, $\operatorname{GdUTi}_{2} \mathrm{O}_{7}$, and the component containing quadravalent cerium, $\mathrm{CaCeTi}_{2} \mathrm{O}_{7}$. Otherwise, the major component in each starting composition is $\mathrm{CaHfTi}_{2} \mathrm{O}_{7}$ with subordinate amounts of $\mathrm{CaUTi}_{2} \mathrm{O}_{7}$ and the aluminum-bearing components. The concentration of the pentavalent uranium-bearing species, $\mathrm{Gd}\left(\mathrm{U}_{0.5} \mathrm{Al}_{0.5}\right)(\mathrm{AlTi}) \mathrm{O}_{7}$, decreases with decreasing $f \mathrm{O}_{2}$ and is balanced by a correlated increase in the quadravalent uranium-bearing species $\mathrm{CaUTi}_{2} \mathrm{O}_{7}$.

Due to the complicated formulation of the hafnolite components, positive concentrations of Ce-bearing components are generated for the Th-analog even though it contains no cerium (Table 9a). An alternative set of components not including ceriumbearing species is a more suitable choice for this composition. To complete the matrix ( 7 cations X 7 components) we add $\mathrm{Ca}\left(\mathrm{Gd}_{0.5} \mathrm{U}_{0.5}\right) \mathrm{Ti}_{2} \mathrm{O}_{7}$, which involves a coupled substitution of $0.5 \mathrm{Gd}+0.5 \mathrm{U} \leftrightarrow \mathrm{Ca}$ the B-site. This alternative set of components decreases the number of negative concentrations (Table 9b), and yields qualitatively similar trends to the 


\begin{tabular}{|c|c|c|c|c|c|c|c|c|}
\hline & $\mathrm{CaHfTi}_{2} \mathrm{O}_{7}$ & $\mathrm{CaThTi}_{2} \mathrm{O}_{7}$ & $\mathrm{CaUTi}_{2} \mathrm{O}_{7}$ & $\mathrm{CaCeTi}_{2} \mathrm{O}_{7}$ & $\mathrm{GdUTi}_{2} \mathrm{O}_{7}$ & $\mathrm{GdAlTi}_{2} \mathrm{O}_{7}$ & $\mathrm{CeAlTi}{ }_{2} \mathrm{O}_{7}$ & $\mathrm{Gd}\left(\mathrm{U}_{0.5} \mathrm{Al}_{0.5}\right) \mathrm{AlTiO}_{7}$ \\
\hline \multicolumn{9}{|c|}{ Ce-Al analog } \\
\hline $7 / 3$ & 0.616 & 0.000 & 0.098 & 0.062 & -0.043 & 0.017 & 0.050 & 0.201 \\
\hline $7 / 4$ & 0.634 & 0.000 & 0.090 & 0.021 & -0.016 & 0.039 & 0.075 & 0.157 \\
\hline $7 / 5$ & 0.673 & 0.000 & 0.072 & -0.031 & -0.004 & 0.037 & 0.124 & 0.129 \\
\hline $7 / 6$ & 0.601 & 0.000 & 0.124 & -0.046 & -0.035 & 0.146 & 0.149 & 0.060 \\
\hline $7 / 9$ & 0.538 & 0.000 & 0.188 & -0.087 & -0.096 & 0.221 & 0.193 & 0.045 \\
\hline $7 / 7$ & 0.575 & 0.000 & 0.158 & -0.104 & -0.044 & 0.165 & 0.211 & 0.039 \\
\hline $7 / 8$ & 0.534 & 0.000 & 0.192 & -0.136 & -0.023 & 0.225 & 0.234 & -0.026 \\
\hline \multicolumn{9}{|c|}{$\mathrm{Ce}$ analog } \\
\hline $1 / 9$ & 0.752 & 0.000 & 0.030 & -0.015 & 0.039 & 0.071 & 0.102 & 0.021 \\
\hline $1 / 7$ & 0.769 & 0.000 & 0.021 & -0.027 & 0.053 & 0.071 & 0.111 & 0.004 \\
\hline $1 / 8$ & 0.729 & 0.000 & 0.046 & -0.043 & 0.079 & 0.137 & 0.127 & -0.076 \\
\hline \multicolumn{9}{|c|}{ Th analog } \\
\hline $8 / 4$ & 0.792 & 0.018 & 0.082 & 0.080 & -0.045 & 0.088 & -0.080 & 0.066 \\
\hline $8 / 5$ & 0.778 & 0.023 & 0.093 & 0.062 & -0.052 & 0.102 & -0.062 & 0.056 \\
\hline $8 / 6$ & 0.835 & 0.022 & 0.040 & 0.044 & -0.027 & 0.033 & -0.044 & 0.097 \\
\hline $8 / 9$ & 0.792 & 0.026 & 0.069 & 0.043 & -0.050 & 0.075 & -0.043 & 0.088 \\
\hline $8 / 8$ & 0.724 & 0.045 & 0.101 & -0.085 & 0.019 & 0.188 & 0.085 & -0.077 \\
\hline
\end{tabular}

\begin{tabular}{|l|r|r|r|r|r|r|r|}
\hline \multicolumn{2}{|c|}{ Table $\mathrm{Xb}$. Concentrations of alternate hafnolite components in Th-analog } \\
\hline & $\mathrm{CaHfTi}_{2} \mathrm{O}_{7}$ & $\mathrm{CaThTi}_{2} \mathrm{O}_{7}$ & $\mathrm{CaUTi}_{2} \mathrm{O}_{7}$ & $\mathrm{GdUTi}_{2} \mathrm{O}_{7}$ & $\mathrm{GdAlTi}_{2} \mathrm{O}_{7}$ & $\mathrm{CaGd}_{0.5} \mathrm{U}_{0.5} \mathrm{Ti}_{2} \mathrm{O}_{7}$ & $\left.\mathrm{Gd}_{(} \mathrm{U}_{0.5} \mathrm{Al}_{0.5}\right) \mathrm{AlTiO}_{7}$ \\
\hline $8 / 4$ & 0.792 & 0.018 & 0.002 & -0.045 & 0.008 & 0.160 & 0.066 \\
$8 / 5$ & 0.778 & 0.023 & 0.030 & -0.052 & 0.040 & 0.125 & 0.056 \\
$8 / 6$ & 0.835 & 0.022 & -0.004 & -0.027 & -0.017 & 0.088 & 0.097 \\
$8 / 9$ & 0.792 & 0.026 & 0.025 & -0.050 & 0.031 & 0.087 & 0.088 \\
$8 / 8$ & 0.724 & 0.045 & 0.186 & 0.019 & 0.272 & -0.169 & -0.077 \\
\hline
\end{tabular}


original component set in which $\mathrm{U}^{+5}$ components are consumed during reduction, replaced by $\mathrm{U}^{+4}$-bearing components.

\subsubsection{Perovskite}

Perovskite, nominally $\mathrm{CaTiO}_{3}$, is cation deficient in these experiments and commonly has $\sim 1$ Ti cation per 2 total cations (Tables 4 and 6 ). A charge excess is produced on the Ca-site if the remaining cations are assigned there, suggesting that all of the vacancies

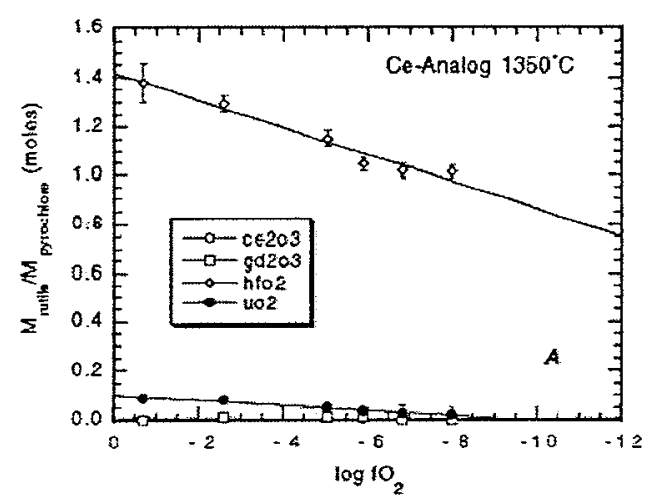

reside on the Ca-site. With the exception of $\mathrm{CeAlO}_{2}$, in which $\mathrm{Ce}^{+3}$ on the Ca-site is compensated by $\mathrm{Al}$ on the Ti-site, we have chosen components that have either $1 \mathrm{Ti}$ or 1 Hf per 2 cations. The non-stoichiometry is assigned to the $\mathrm{Ca}$-site alone resulting in the following components: $\mathrm{CaTiO}_{3}, \mathrm{CaHfO}_{2}$, $\square_{0.33} \mathrm{Al}_{0.66} \mathrm{TiO}_{3}, \quad \square_{0.33} \mathrm{Ce}_{0.66} \mathrm{TiO}_{3}$,

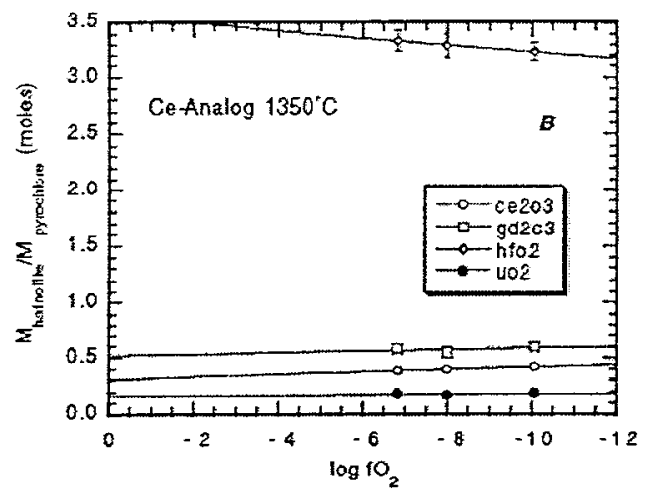

$\square_{0.33} \mathrm{Gd}_{0.66} \mathrm{TiO}_{3}, \quad \mathrm{CeAlO}_{2}, \quad \square_{0.5} \mathrm{Th}_{0.5} \mathrm{TiO}_{3}$, $\square \square_{0.5} \mathrm{U}_{0.5} \mathrm{TiO}_{3}$ (where $\square$ is a cation vacancy). The only stoichiometric components are $\mathrm{CaTiO}_{3}, \mathrm{CaHfO}_{3}$, and $\mathrm{CeAlO}_{2}$. The others all have vacancies on the Ca-site. Negative concentrations are obtained are for only $\square{ }_{0.33} \mathrm{Al}_{0.66} \mathrm{TiO}_{3}$ and even these are not significantly different from zero (Table 10). $\mathrm{CaTiO}_{3}$ and $\square_{0.33} \mathrm{Ce}_{0.66} \mathrm{TiO}_{3}$ are the

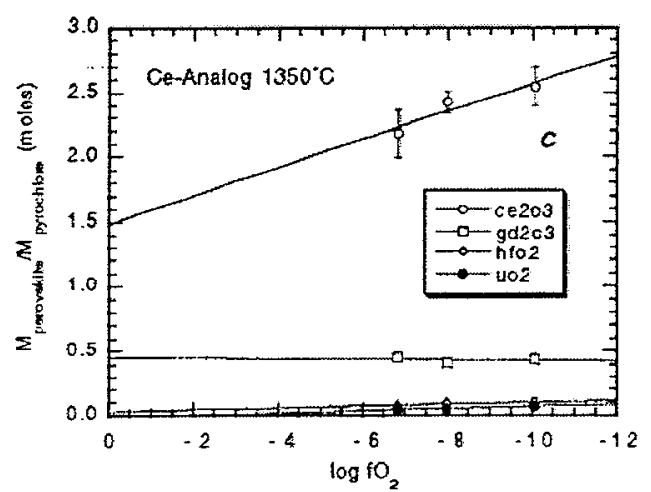

Figure 23. Partition coefficients as a function of oxygen fugacity for the Ce-analog experiments. (A) rutile/pyrochlore, (B) hafnolite/pyrochlore, (C) perovskite/pyrochlore. predominant species with minor $\square_{0.33} \mathrm{Gd}_{0.66} \mathrm{TiO}_{3}$.

\subsection{Element Partitioning}

The smooth variation in mineral composition with changing $\mathrm{fO}_{2}$ is reflected in similar variations in the partition coefficients which are qualitatively similar for each of the analog compositions (Figures 23, 23, 24). All of the partition coefficients are given relative to pyrochlore and expressed as oxide molar 
ratios.

The data are sparse for the Ce-analog due to the low number of phases found in the runs performed at higher $\mathrm{fO}_{2} \mathrm{~s}$. The greatest number of data are for rutile-pyrochlore partitioning and demonstrate the relative incompatibility of uranium in rutile relative to pyrochlore $\left(\mathrm{D}^{\mathrm{rut} / \mathrm{py}}<0.1\right)$. The incompatibility becomes more pronounced with decreasing $\mathrm{fO}_{2}$ (Fig. 23a). This variation with $\mathrm{fO}_{2}$ is also the case for hafnium which favors rutile at
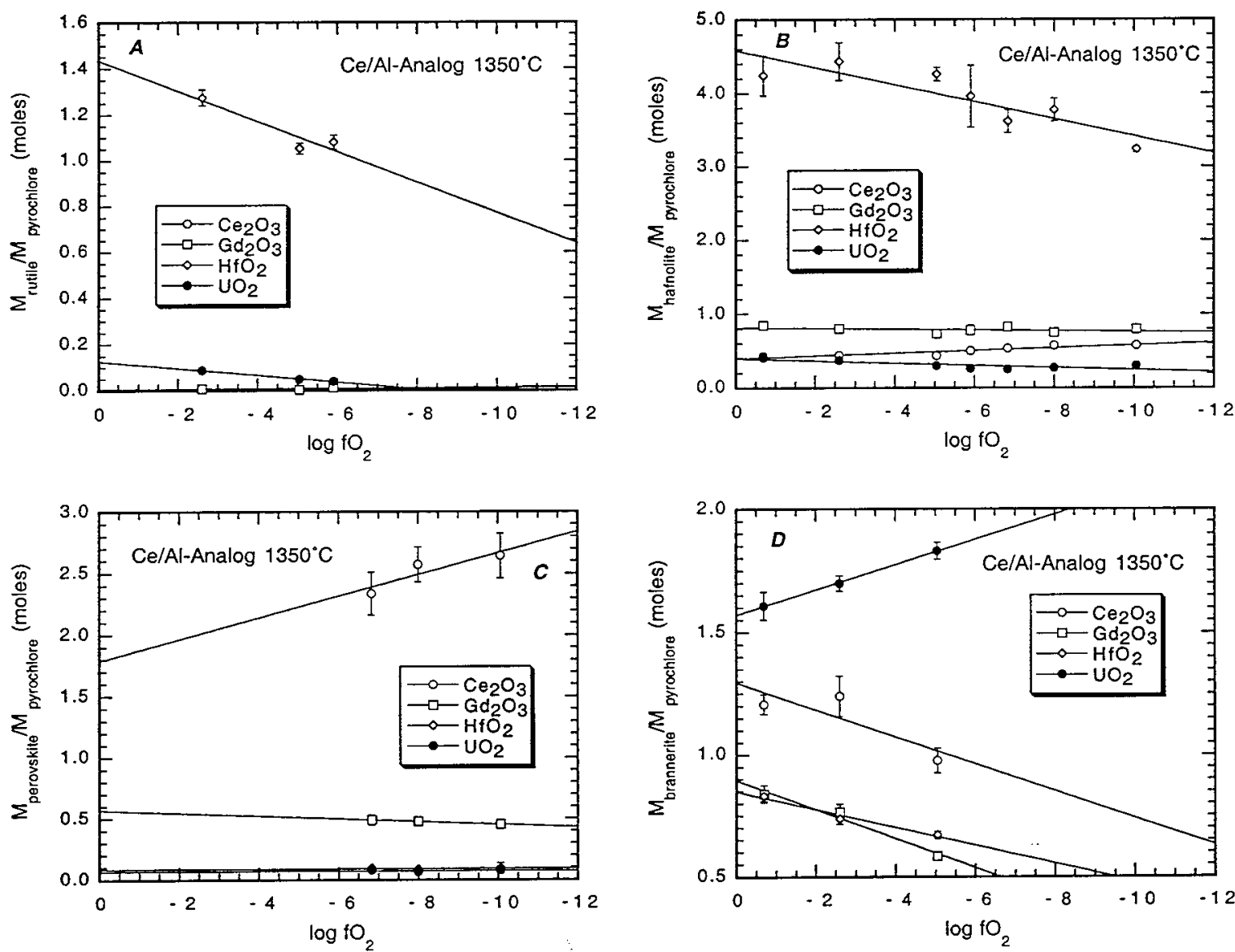

Figure 24. Partition coefficients as a function of oxygen fugacity for the Ce-analog experiments.
(A) rutile/pyrochlore,
(B) hafnolite/pyrochlore,
(C) perovskite/pyrochlore,
(D) brannerite/pyrochlore.

high $\mathrm{fO}_{2}$, and is equally partitioned between rutile and pyrochlore $\left(\mathrm{D}^{\mathrm{rut} / \mathrm{py}}=1.0\right)$ at $-\log$ $\mathrm{fO}_{2}=10$ (Fig. 23a). Hafnium is strongly partitioned into hafnolite relative to pyrochlore (Figure 23b). The composition of hafnolite is also relatively constant in these experiments which is demonstrated by the constant values of $\mathrm{D}^{\mathrm{hfn} / \mathrm{py}}$ for $\mathrm{Ce}_{2} \mathrm{O}_{3}, \mathrm{Gd}_{2} \mathrm{O}_{3}, \mathrm{HfO}_{2}$ and $\mathrm{UO}_{2}$ (Figure 23b). The lanthanides are fractionated by pyrochlore and perovskite, with $\mathrm{Ce}$ compatible in perovskite and Gd more compatible in pyrochlore (Fig. 23c). $\mathrm{D}^{\mathrm{pv} / \mathrm{py}}$ for 


\begin{tabular}{l}
\hline Table 10. Mole fractions of perovskite components \\
\hline
\end{tabular}


$\mathrm{Gd}_{2} \mathrm{O}_{3}$ is constant with respect to changing $\mathrm{fO}_{2}$, but that of Ce increases with decreasing $\mathrm{fO}_{2}$ (Figure 23c). The changing behavior of Ce relative to $\mathrm{Gd}$ may indicate that at least

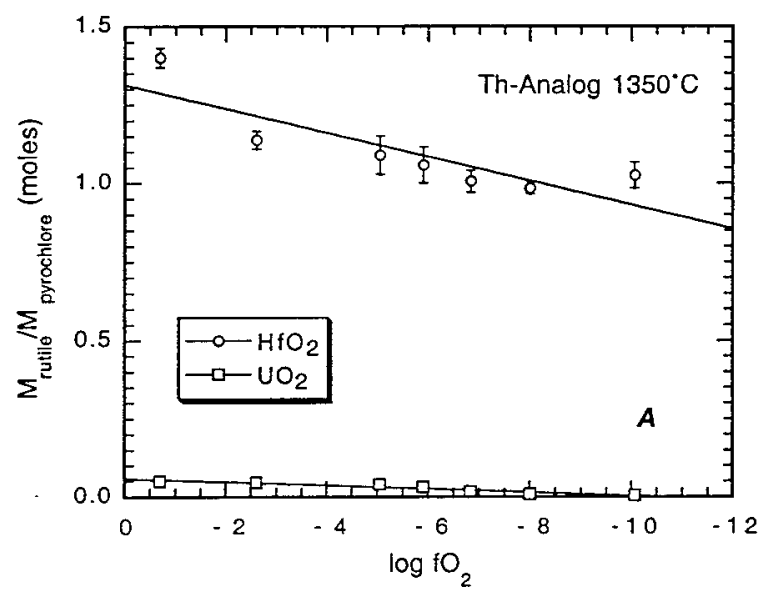
some cerium is present in the quadravalent state, and becomes more compatible in perovskite as it is converted to $\mathrm{Ce}^{+3}$. However, the pyrochlore structure is capable of accommodating a wide variety of composition variations, and the partitioning of cerium could be changing in response to changes in other components.

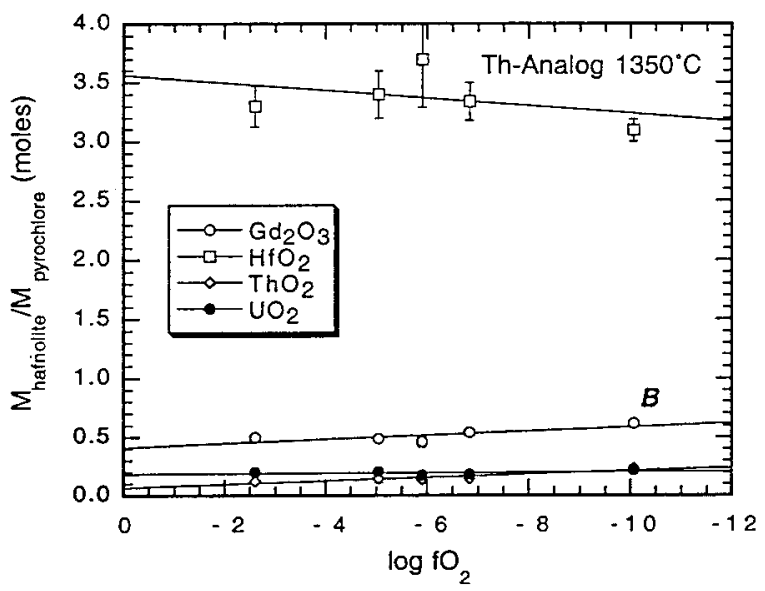

The major effect of adding $\mathrm{Al}_{2} \mathrm{O}_{3}$ to the Ce-analog is to stabilize hafnolite over the full range of $\mathrm{fO}_{2} \mathrm{~s}$ sampled. In addition, brannerite is also stable in a greater number of runs and an Al-rich accessory phase is always present. However, the addition of $\mathrm{Al}_{2} \mathrm{O}_{3}$ has little effect on the values of the partition coefficients relative to those in the Al-

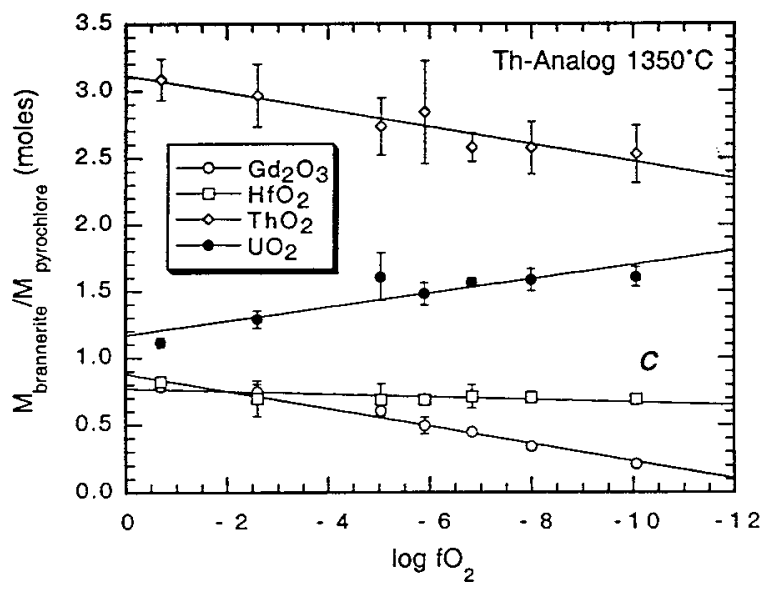
free $\mathrm{Ce}$-analog. For instance, the values of $\mathrm{D}^{\text {rutpy }}$ are virtually indistinquishable in these two compositions (Figure 23a and 24a). Similarly, the values of $D^{\text {hfn/py }}$ for are quite similar in both relative and absolute magnitude in both compositions (Figure 23b and 24b), though a slight decrease in $D^{\text {hfn/py }}$ for cerium is suggested by the greater number of data for the $\mathrm{Ce} / \mathrm{Al}$ analog.

Figure 25. Partition coefficients as a function of oxygen fugacity for the Th-analog experiments. (A) rutile/pyrochlore, (B) hafnolite/pyrochlore, $\mathrm{D}^{\mathrm{pu} / \mathrm{py}}$ for the $\mathrm{Ce}-\mathrm{Al}$ analog is also virtually identical to that in the Al-free 
composition and confirms that fractionation of $\mathrm{Ce}$ and $\mathrm{Gd}$ by these phases (Figure 23c). The negligible effect of aluminum on the partitioning relationships is consistent with the partitioning of aluminum itself which is strongly concentrated in Al-rich accessory minerals. The low concentrations in hafnolite, pyrochlore, rutile and perovskite preclude any coupled substitutions based on Al-rich components that would affect changes in the activity-composition relationships for the other elements.

Brannerite in also stable is some of the higher $\mathrm{fO}_{2}$ runs from the $\mathrm{Ce}-\mathrm{Al}$ analog. The broad range in pyrochlore compositions observed in the $\mathrm{CaO}-\mathrm{HfO}_{2}-\mathrm{UO}_{2}$ ternary (Figure 14 ) is reflected in variations of $\mathrm{D}^{\mathrm{br} / \mathrm{py}}$ with $\mathrm{fO}_{2}$ (Fig 24d). Consistent with the increased $\mathrm{U}$ concentrations with $\mathrm{fO}_{2}$ (Figure 18), $\mathrm{D}^{\text {broppy }}$ for $\mathrm{UO}_{2}$ increases as $\mathrm{fO}_{2}$ falls (Figure 24d). $\mathrm{D}^{\mathrm{brn} / \mathrm{py}}$ for Ce, Gd and Hf display the opposite effect. The increase in $\mathrm{D}^{\mathrm{brn} / \mathrm{py}}$ with $\mathrm{fO}_{2}$ may reflect the reduction of uranium shown in Figure 19.

Unlike uranium, thorium does not enter rutile in detectable amounts (Table 7). It does, however, enter pyrochlore $(\sim 8 \mathrm{wt} \%)$ and hafnolite $(\sim 1 \mathrm{wt} \%)$. Nevertheless, the effect on the partitioning of other elements ( $\mathrm{Gd}, \mathrm{U}$ and $\mathrm{Hf}$ ) between pyrochlore, hafnolite and rutile is negligible (Figure 25a, b). This is consistent with Th forming a CaThTi $\mathrm{O}_{7}$ component in both pyrochlore and hafnolite, which dilutes that other components, but doesn't alter their activity-composition relationships.

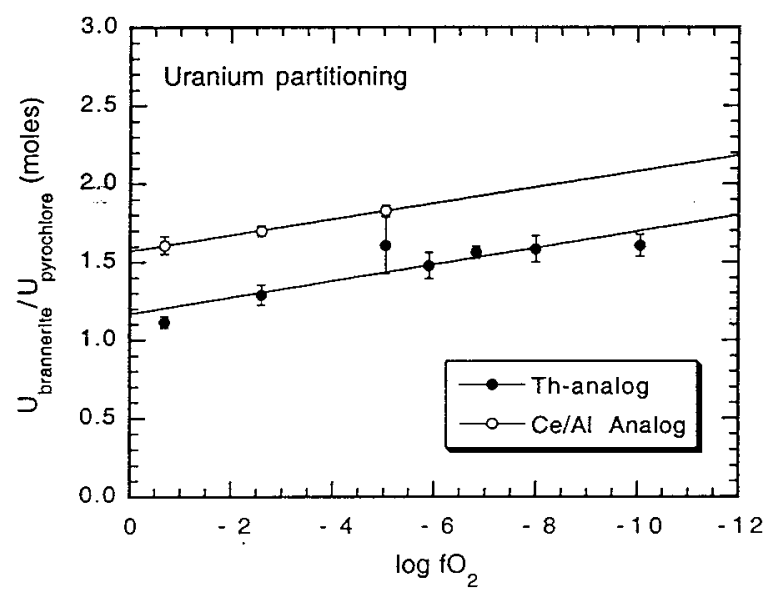

Figure 26. Partitioning of uranium between brannerite and pyrochlore for the $\mathrm{Th}$ and $\mathrm{Ce} / \mathrm{Al}$ analogs.
The major effect of thorium addition is the stabilization of brannerite under all conditions (Table 3 ). $\mathrm{D}^{\mathrm{brn} / \mathrm{py}}$ is between 2.5 and 3 over the range of $\mathrm{fO}_{2} \mathrm{~s}$ sampled, and its enrichment in brannerite stabilizes that phase. While $D^{\text {brn/py }}$ for thorium decreases slightly with decreasing $\mathrm{fO}_{2}, \mathrm{D}^{\mathrm{brn} / \mathrm{py}}$ for uranium increases (Figure 25c) which may reflect the conversion of $\mathrm{U}^{+6}$ to $\mathrm{U}^{+4}$. However, even at the lowest $\mathrm{fO}_{2} \mathrm{~s}$, where our model calculations indicate that virtually all of the uranium is present at $\mathrm{U}^{+4}$ (Figure 18 and 19$), D^{\text {brn/py }}$ for $T h$ is greater that $\mathrm{D}^{\mathrm{brn} / \mathrm{py}}$ for uranium indicating that $\mathrm{Th}^{+4}$ is more compatible in brannerite than $\mathrm{U}^{+4}$ (Fig. 25c). This conclusion is consistent with the observation that $\mathrm{D}^{\mathrm{brn} / \mathrm{py}}$ for uranium in the $\mathrm{Ce} / \mathrm{Al}$ analog samples is always higher than it is in the Th-analog at the same $\mathrm{fO}_{2}$ (Figure 26). 
Thorium and cerium were both intended to act a analogs for plutonium, and the variation of $\mathrm{D}^{\mathrm{bm} / \mathrm{py}}$ with $\mathrm{fO}_{2}$ for these element (as well as gadolinium) is similar (Figure 25). However, the absolute value of $D^{\text {brapy }}$ is quite different, however, as thorium is more than a factor of two more strongly enriched in brannerite than cerium. $D^{\mathrm{brn} / \mathrm{py}}$ for cerium more closely resembles that of gadolinium, suggesting that cerium is trivalent in these experiments (Fig. 27).

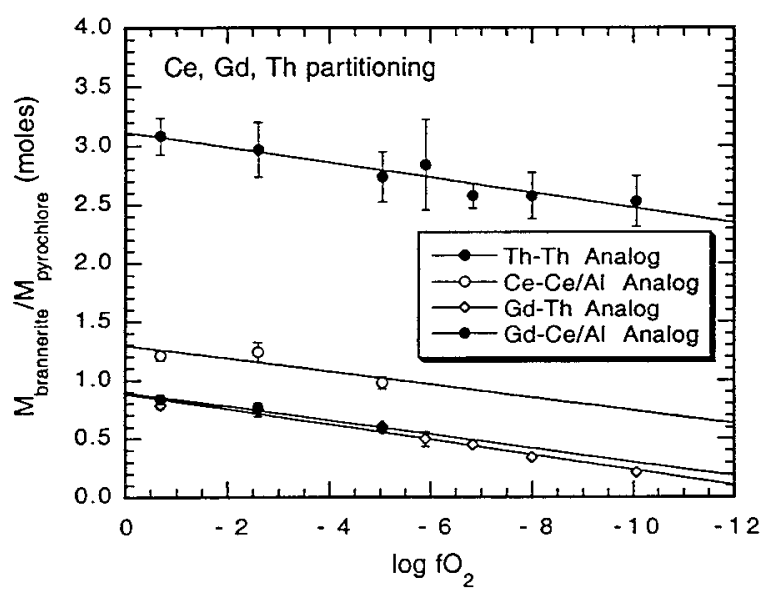

Figure 27. Partitioning of $\mathrm{Ce}, \mathrm{Gd}$ and $\mathrm{Th}$ between brannerite and pyrochlore for the $\mathrm{Th}$ and $\mathrm{Ce} / \mathrm{Al}$ analogs.

\subsection{Phase equilibria}

The compositions and synthesis conditions used in these experiments result in high variance phase assemblages in which the number of chemical components exceeds the number of phases. As such, the compositions of the phases are constrained largely by the bulk composition of the starting material rather than by phase equilibria. Taken to its extreme, in an assemblage with only one phase that phase has the exact composition of the starting material. Here the system is characterized by 8 components: $\mathrm{Al}, \mathrm{Ca}, \mathrm{Ti}, \pm \mathrm{Ce}, \mathrm{Gd}, \mathrm{Hf}, \pm \mathrm{Th}$, $\mathrm{U}$ and $\mathrm{O}_{2}$, when cast as elements. The greatest number of phases produced is 5 in some of the $\mathrm{Ce} / \mathrm{Al}$ analog runs, resulting in a variance of 4 under fixed pressure conditions. Nevertheless, we can use the information from some of the lower variance assemblages in the Th-analog and $\mathrm{Ce} / \mathrm{Al}$ analog experiments to observe how the compositions of coexisting phases vary with $\mathrm{fO}_{2}$.

The compositions of rutile, hafnolite and the calcium aluminotitanate phase are relatively constant in these experiments compared with those of pyrochlore and brannerite. As such, they can be used as "projection points' from which the compositions of phases with these minerals can be projected from n-dimensional compositional space into the ternary systems of interest. By constraining the assemblages to be in equilibrium with these saturating phases, we buffer the activities of these components described by the projection points, eliminating the effect of variations in these activities on the compositions of the coexisting minerals. In all cases, these are simplifications as the number of phases present is not sufficient to buffer all of the components within the system. 
In the Th-analog runs all of the experiments are saturated in rutile and hafnolite. We have projected the compositions of coexisting pyrochlore and brannerite onto the $\mathrm{UO}_{2}{ }^{2}-$

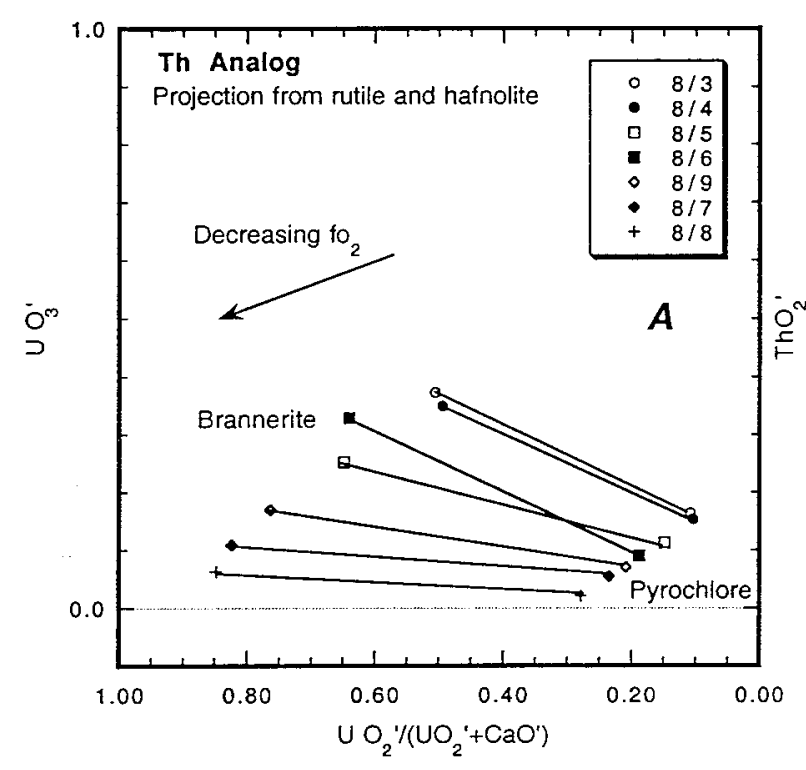

Figure 28. "Phase diagram" for the Th-analog experiments. (A) Projection from rutile and hafnolite onto the $\mathrm{UO}_{2}{ }^{\prime}=\mathrm{CaO}$ '- $\mathrm{UO}_{3}$ ' plane - "prime" indicates that these are projection components which are not equivalent to the real, measured components. The valence state of uranium is calculated assuming ideal trivalent cerium. (B) Projection from rutile and hafnolite onto the $\mathrm{UO}_{2}$ '- $\mathrm{CaO}$ '- $\mathrm{ThO}_{2}$ plane.

$\mathrm{CaO}$ '- $\mathrm{ThO}_{2}$ ' and $\mathrm{UO}_{2}$ '- $\mathrm{CaO}$ '- $\mathrm{UO}_{3}$ ' ternaries in Figure 28. The "prime" indicates that these are the projected components resulting from the transformation of coordinates and not the measured chemical concentrations. Orthogonal projections are used to facilitate the plotting of negative components. The concentrations of $\mathrm{UO}_{2}$ and $\mathrm{UO}_{3}$ were calculated using the ideal model oxygen stoichiometry in Table 7.

The position and variation with $\mathrm{fO}_{2}$ of brannerite-pyrochlore tielines is similar in both the $\mathrm{UO}_{2}{ }^{\prime}-\mathrm{CaO}^{\prime}-\mathrm{ThO}_{2}$ ' and $\mathrm{UO}_{2}{ }^{\prime}-\mathrm{CaO}^{\prime}-\mathrm{UO}_{3}$ ' projections. The high $\mathrm{fO}_{2}$ runs plot on the low $\mathrm{UO}_{2}^{\prime} /\left(\mathrm{UO}_{2}{ }^{\prime}+\mathrm{CaO}\right)$ side of the diagram and move progressively to higher values as $\mathrm{fO}_{2}$ decreases. In general, the tielines do not cross indicating that the bulk $\left.\mathrm{UO}_{2}{ }^{\prime} /\left(\mathrm{UO}_{2}{ }^{\prime}+\mathrm{CaO}\right)^{\prime}\right)$ is increasing as uranium is reduced from $\mathrm{U}^{+6}$ to $\mathrm{U}^{+4}$. This is clearly shown in the $\mathrm{UO}_{3}$ ' concentrations of the coexisting phases in the $\mathrm{UO}_{2}{ }^{\prime}-\mathrm{CaO}^{\prime}-\mathrm{UO}_{3}$ ' projection (Figure 28a). The changing slope of the brannerite-pyrochlore tieline on the $\mathrm{UO}_{2}$ '- $-\mathrm{CaO}$ '- $-\mathrm{UO}_{3}$ ' projection indicates that the brannerite-pyrochlore partition coefficient for $\mathrm{U}^{+6}$ decreases with $\mathrm{fO}_{2}$. However, the bulk partition coefficient for $\mathrm{UO}_{2}$ (all $\mathrm{U}^{+4}$ ) increases with decreasing $\mathrm{fO}_{2}$ (Fig $25 \mathrm{c}$ ) indicating that the increase in $\mathrm{D}^{\mathrm{brm} / \mathrm{py}}$ for quadravalent $\mathrm{U}$ more than compensates for the decrease in $\mathrm{U}^{+6}$. The brannerite-pyrochlore tielines on the $\mathrm{UO}_{2}$ '- 
$\mathrm{CaO}-\mathrm{ThO}_{2}$ ' projection are much closer to parallel that those in the $\mathrm{UO}_{2}{ }^{\prime}-\mathrm{CaO}^{\prime}-\mathrm{UO}_{3}$ projection, and the variation in the $\mathrm{ThO}_{2}$ ' concentration is much less pronounced. This is consistent with the single valence state for Th.

Rutile and hafnolite can also be used to project the compositions of coexisting phases in the $\mathrm{Ce} / \mathrm{Al}$ analog into various ternary systems. The position of the 3-phase assemblage, brannerite-pyrochlore-calcium aluminotitanate, projected on the $\mathrm{UO}_{2}{ }^{\prime}-\mathrm{CaO}^{\prime}-\mathrm{UO}_{3}$ ' shows the variation in uranium oxidation state with changing $\mathrm{fO}_{2}$ (Figure 29a); $\mathrm{U}^{+6}$ is calculated assuming all of the cerium is present as $\mathrm{Ce}^{+3}$ and stoichiometry is ideal. At high $\mathrm{fO}_{2}$ the three phase field lies at low $\mathrm{UO}_{2}{ }^{\prime} /\left(\mathrm{UO}_{2}{ }^{\prime}+\mathrm{CaO}^{\prime}\right)$. As $\mathrm{fO}_{2}$ is reduced, the field rotates counterclockwise as uranium is reduced. As in the Th-analog, the brannerite-pyrochlore
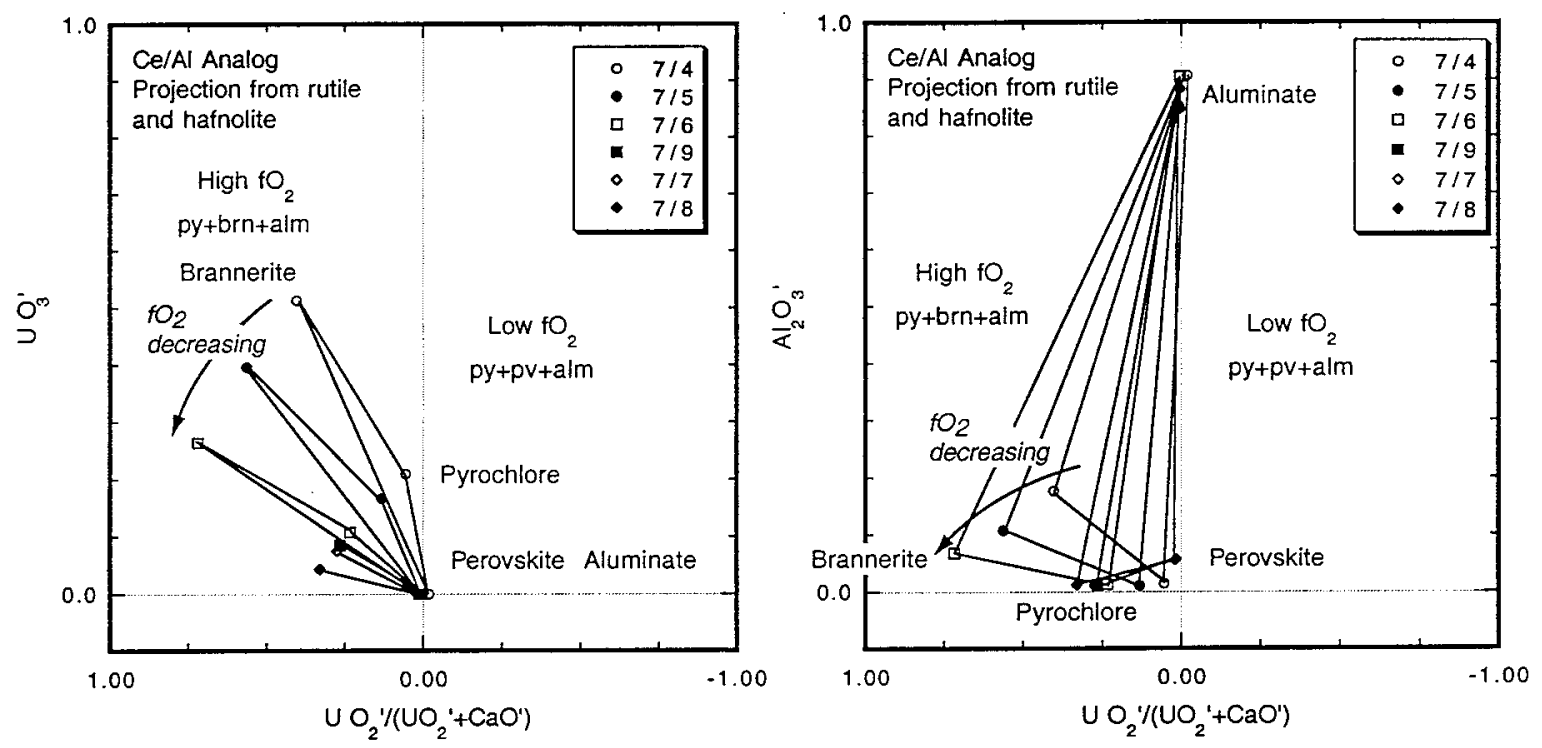

Figure 29. "Phase diagram" for the Ce/Al-analog experiments. (A) Projection from rutile and hafnolite onto the $\mathrm{UO}_{2}{ }^{\prime}=\mathrm{CaO}-\mathrm{UO}_{3}$ ' plane - "prime" indicates that these are projection components which are not equivalent to the real, measured components. The valence state of uranium is calculated assuming ideal trivalent cerium. (B) Projection from rutile and hafnolite onto the $\mathrm{UO}_{2}$ '- $\mathrm{CaO}$ '- $\mathrm{Al}_{2} \mathrm{O}_{3}$ ' plane.

partition coefficient for uranium decreases with decreasing $\mathrm{fO}_{2}$. As the field rotates the pyrochlore approaches colinearity with brannerite and the aluminotitanate and brannerite disappears and is replaced by perovskite.

Perovskite and the calcium aluminotitanate phase plot at the same point in the $\mathrm{UO}_{2}$ '$\mathrm{CaO}^{\prime}-\mathrm{UO}_{3}$ ' projection, obscuring the phase relationships. They are better observed on the $\mathrm{UO}_{2}{ }^{\prime}-\mathrm{CaO}^{\prime}-\mathrm{Al}_{2} \mathrm{O}_{3}$ ' projection (Figure 29b). At high $\mathrm{fO}_{2}$ the assemblage is pyrochlore, brannerite, aluminate, rutile and hafnolite. As $\mathrm{fO}_{2}$ decreases brannerite becomes depleted 
in $\mathrm{Al}_{2} \mathrm{O}_{3}$, and the pyrochlore-brannerite tieline rotates toward the $\mathrm{x}$-axis. Eventually brannerite becomes unstable and is replaced by perovskite. Pyrochlore continues to increase in $\mathrm{UO}_{2}{ }^{\prime}$ as it is now the only significant host for uranium. The reaction sequence in this projection has crossing tielines largely due to its inability of represent the uranium reduction that occurs.

\section{Conclusions}

Ce-, Th- and Al-doped Ce-analogs of titanate-based Pu-immobilization ceramics demonstrate systematic variations in mineral chemistry and phase assemblage with variations in oxygen fugacity. These variations seem to be largely due to the reduction of uranium under more reducing conditions. In spite variations in $\mathrm{fO}_{2}$ of greater than 10 orders of magnitude, all of the phases encountered here have been previously observed in the SYNROC family of titanate ceramics (Ringwood et al., 1979; Ryerson, 1984; Lumpkin et al., 1994); Ryerson (1984) obtained similar results for a SYNROC formulation for the immobilization of US Defense wastes. The desired phase assemblage, pyrochlore+brannerite+rutile is favored by more oxidizing conditions, however. Reduction leads to the formation of perovskite and a calcium aluminotitanate. Both of these phases incorporate lanthanides in the analog materials, and are likely to incorporate plutonium in the actual immobilization wasteform.

\section{References}

Armstrong, J.T. CITZAF: a package of correction programs for the quantitative electron microbeam analysis of thick polished materials, thin films and particles. Microbeam Anal., 4, 177-200, 1995.

Ebbinghaus, B.B., C. Cicero-Herman, L. Gray and H. Shaw, Plutonium immobilization project: Baseline Formulation, Lawrence Livermore National Laboratory, 1999.

Lumpkin, G.R., K.P. Hart, P.J. McGlinn, and T.E. Payne, Retention of actinides in natural pyrochlores and zirconolites, Radiochimica Acta, 66/67, 460-474, 1994.

Ringwood, A.E., S.E. Kesson, N.G. Ware, W. Hibberson, and A. Major, Immobilization of high level nuclear reactor waste in SYNROC, Nature, 278, 219-223, 1979.

Ryerson, F.J., Phase equilibria in nuclear waste ceramics: The effect of oxygen fugacity, $J$. Am. Ceram. Soc, 67, 75-82, 1984. 
Subramanian, M.A., G. Aravamudan, and G.V. Subba Rao, Oxide pyrochlores-A review, Progress in Solid State Chemistry, 15, 55-143, 1983.

Appendix A. Electron Probe Standards and $x$-ray lines

\begin{tabular}{lll} 
Element & X-Ray Lines & Standard \\
\hline $\mathrm{Al}$ & $\mathrm{Al}_{K \alpha}$ & $\mathrm{Al}_{2} \mathrm{O}_{3}$ \\
$\mathrm{Ca}$ & $\mathrm{Ca}_{K \alpha}$ & $\mathrm{CaSiO}_{3}$ \\
$\mathrm{Ti}$ & $\mathrm{Ti}_{K \alpha}$ & $\mathrm{TiO}_{2}$ \\
$\mathrm{Ce}$ & $\mathrm{Ce}_{L \beta 1}$ & $\mathrm{CeO}_{2}$ \\
$\mathrm{Gd}$ & $\mathrm{Gd}_{L \beta 1}$ & $\mathrm{Gadolinium}$ Gallium Garnet \\
$\mathrm{Hf}$ & $\mathrm{Hf}_{L}$ & $\mathrm{Hf}-\mathrm{Zr}$ alloy \\
$\mathrm{Th}$ & $\mathrm{Th}_{M \beta 1}$ & $\mathrm{ThO}_{2}$ \\
$\mathrm{U}$ & $\mathrm{U}_{M \beta 1}$ & $\mathrm{UO}_{2}$ \\
\hline
\end{tabular}

